\title{
Growth and Convergence across the US: Evidence from County-Level Data
}

\author{
Matthew Higgins \\ Department of Economics \\ Emory University \\ Atlanta, GA 30322 \\ Matthew_Higgins@bus.emory.edu \\ 404-727-1022 \\ Daniel Levy \\ Department of Economics \\ Bar-Ilan University \\ Ramat Gan 52900, ISRAEL \\ Levyda@mail.biu.ac.il \\ 972-3-531-8331 \\ and \\ Department of Economics \\ Emory University \\ Atlanta, GA 30322-2240 \\ ECONDL@emory.edu \\ 404-727-2941 \\ Andrew Young \\ Department of Economics \\ Emory University \\ Atlanta, GA 30322-2240 \\ Atyoung@emory.edu \\ 404-727-1022 \\ JEL Codes: O40, O11, O18, R11 \\ Last Revision: February 12, 2003
}

We are grateful to Paul Evans for answering our questions and for commenting on the previous version of the manuscript. Jordan Rappaport kindly shared with us his data and provided helpful suggestions and advice throughout the study. We also thank Paul Rubin and Jacqui Silber for answering our questions, and Bob Barsky, Bob Chirinko, Eric Hallerberg, Jesse Hamner, Nazrul Islam, Joy Mazumdar, and Som Somanathan for helpful conversations. All errors are ours.

C2003 by Matthew Higgins, Daniel Levy, and Andrew Young. All rights reserved. Short sections of text not to exceed two paragraphs, may be quoted without explicit permission provided that full credit including @notice, is given to the source. 


\title{
Growth and Convergence across the US: Evidence from County-Level Data
}

\begin{abstract}
We use U.S. county-level data consisting of 3,058 observations, to study growth determination and measure the speed of income convergence. County-level data are particularly valuable for studying convergence because they allow us to study a sample with substantial homogeneity and exceptional mobility of capital, labor and technology without sacrificing the benefits of a large number of cross-sectional units. Our data set allows us to include nearly 40 different conditioning variables to study their effect on the counties' balanced growth paths. We report estimates using a 2SLS instrumental variables method which yields consistent estimates, as well as estimates from standard OLS. In order to explore possible heterogeneity in the conditional convergence rates, we report the estimates for the entire data set as well as for subsets including metro counties, non-metro counties, and five regional groupings. Our findings include: (i) while OLS yields convergence rates around 2 percent, the 2SLS method yields rates between 6 and 8 percent; (ii) the estimated convergence rates are not constant across the U.S., for example, the counties in the Southern states converge at a rate that is more than two and half times faster than the counties located in the New England states; (iii) the extent of the public sector at all levels (federal, state and local) negatively affects growth and there is no evidence of the public sector becoming more productive at more decentralized levels; (iv) the relationship between a population's educational attainment and economic growth is nonlinear depending on the years of education considered; and (v) large presences of both finance, insurance and real estate industry and entertainment industry are positively correlated with growth while the percent of a county's population employed in the education industry is negatively correlated with economic growth.
\end{abstract}




\section{Introduction}

"Economies converge at a speed of about two percent per year." This is what Sala-i-Martin (1996, p. 1326) put forth as a "mnemonic rule" of economic growth empirics. Sala-i-Martin was referring to how quickly an economy will converge to its individual balanced growth path for per capita income. Results in line with this rule were first reported by Barro and Sala-i-Martin (1991, 1992) and Mankiw, et al. (1992). ${ }^{1}$ The econometric specification popularized by these papers is based on the neoclassical growth models of Ramsey (1928), Solow (1956), Swan (1956), Cass (1965) and Koopmans (1965). Under this specification, the average growth rate of per capita income is regressed on the initial value of per capita income and on the initial values of a set of conditioning variables using OLS. From the coefficient on initial per capita income, which is predicted to be negative under the convergence hypothesis, the conditional convergence rate can be inferred.

In this paper we study growth determination and measure the speed of income convergence within the U.S. In so doing we make four contributions to the empirical economic growth literature.

First, we have assembled unusually rich county-level data that offer numerous advantages. In contrast to 100-150 observations (typical for existing data sets) our data contain 3,058 observations, yielding more precise estimates. The U.S. county data are collected by a single institution, ensuring considerable uniformity of variable definitions. There is also no exchange rate variation between the counties and the price variation across counties is smaller than across countries. Further, U.S. counties are far more homogeneous than countries. Finally, U.S. counties are characterized by exceptional mobility of resources and factors. ${ }^{2}$

Second, the large number of cross-sectional observations allows us to examine, not only the full sample, but also regional groups (New England, Great Lakes, Western, Plains and Southern States) and metro and non-metro groups. Doing so controls for

\footnotetext{
${ }^{1}$ Quah (1996) and Sala-i-Martin (1996) survey some of the literature that followed these seminal studies and explore possible explanations to the uniform $2 \%$ convergence findings. For a more recent survey, see Brock and Durlauf (2001).

${ }^{2}$ Many of these virtues are, of course, embodied in state-level data used by, e.g. Barro and Sala-i-Martin (1991) and Evans (1997a). However, state-level data sacrifices the large number of observations that we have.
} 
possible cross-regional heterogeneity in convergence parameters and the parameters determining the effect of conditioning variables on the level of the balanced growth path, which is quite important as emphasized by Brock and Durlauf (2001). ${ }^{3}$

Third, we are able to use nearly 40 different conditioning variables and still retain substantial degrees of freedom. ${ }^{4}$ The inclusion of a large number of explanatory variables in the growth regression is useful for assessing the empirical relevance of various determinants of balanced growth path positions. ${ }^{5}$

Fourth, we use a cross-sectional variant of a 2SLS approach suggested recently by Evans (1997a, 1997b). Evans (1997b) shows that for the consistency of OLS estimates the data must satisfy highly implausible conditions. He proposes a 2SLS method which produces consistent estimates. He applies the method to a sample of 85 countries and reports convergence rates of between 8-9 percent. Evans (1997a) then adapts the method to panel data and studies both international data and state-level data from the U.S. He estimates rates of convergence of about 6 percent across countries and 16 percent across the U.S. ${ }^{6}$ If the bias of OLS estimates has caused underestimation of the speed of convergence then this has important implications for how we view the plight of laggard economies. E.g., a convergence rate of 2 percent means that economies close the gap between their current position and their balanced growth path in approximately 34 years. However, if the actual convergence rate is 6 percent then the gap is closed in 11 years; if

\footnotetext{
${ }^{3}$ Our estimation method (section 2) effectively differences out heterogeneity in balanced growth paths before estimating the convergence rate in the first stage. However, looking at regions and metro/non-metro counties separately is useful because, firstly, there may be heterogeneity across regions in the convergence rate parameters and, secondly, there may be heterogeneity in the parameters representing the effects of conditioning variables (estimated in the second stage).

${ }^{4}$ Previous cross-country studies have used as many as 90 different variables as potential growth determinants (Durlauf and Quah, 1999; Durlauf, 2001). As Brock and Durlauf (2001) emphasize, however, there are ".. at best about 120 countries data available for analysis in cross-sections (the number may be far smaller as a result of missing observations on some covariates), [and therefore] it is far from obvious how to formulate firm inferences about any particular explanation of growth" (p. 7). Given the large data set, we do not face these kinds of constraints.

${ }^{5}$ This is further underscored by the fact that the speed of convergence to the balanced growth path is only half the story. A poor economy will never find par with a wealthy economy if the poor economy is converging - no matter how quickly - to a balanced growth path that is below that of the wealthy country. In the words of Islam (1995, p. 1162), “... there is probably little solace to be derived from finding that [economies] are converging at a faster rate, when the points to which they are converging are very different." Evans (1997a) does not use conditioning variables, while Evans (1997b) includes only the investment to output ratio, a measure of schooling, and the growth rate of the labor force, a la Mankiw, et al. (1992).

${ }^{6}$ See also Evans (1996) and Evans and Karras (1996).
} 
it is 16 percent the gap will be closed in 4 years. We report both 2SLS consistent estimates as well as OLS estimates. This makes our work directly comparable to the studies that employ the OLS while offering results from an improved methodology as well. $^{7}$

Our main findings are as follows. First, we find that the estimated rate of conditional convergence across U.S. counties is between 6 and 8 percent when the 2SLS method is applied. In contrast, the OLS method yields an estimate right around the 2 percent mnemonic rule. ${ }^{8}$ Thus our results for county-level data using the 2 SLS method are in line with the findings reported by Evans (1997b) and are supportive of considerably higher convergence rates than reported in the majority of the previous studies - certainly higher than the estimates reported in the studies that employ the OLS method. ${ }^{9}$

Second, we find a substantial variation in regional convergence rates, e.g., the counties in the Southern region converge at a rate that is more than two and half times faster than the counties located in the New England region.

Third, we find that the percent of a county population employed by government at all levels (federal, state or local) is negatively correlated with economic growth. Government, even at the least centralized level, tends to lower the balanced growth path of an economy and there is no evidence of government becoming less detrimental at more decentralized levels. This suggests that the absence of positive effects cannot be explained by positive spillovers across geographic units.

Fourth, we discover a nonlinear relationship between economic growth and measures of per capita human capital stock. While the percent of a county's population holding a high-school degree and no higher, and the percent of the population holding a bachelor's degree or more, are positively related to economic growth, the percent of a

\footnotetext{
${ }^{7}$ We follow Evans (1997b) in using instrumental variables in the first stage, enabling us to address the potential problem of endogeneity as emphasized by Evans and also Durlauf (2001).

${ }^{8}$ We refer here to results for the three samples spanning the entire U.S.: full sample, metro counties, and non-metro counties. Regional estimates will be discussed separately below.

${ }^{9}$ While the point estimates of the convergence rates reported by Evans (1997a) for the U.S. states appear quite high, we should point out that he found them considerably variable. Moreover, his estimates have wide confidence intervals. Therefore, his estimates may not be significantly different from ours in a statistical sense.
} 
county's population holding an associate's degree and no higher is negatively correlated with economic growth.

Fifth, we find that a large presence of financial, insurance, and real estate industry, as well as the entertainment industry, is positively correlated with economic growth. On the other hand, the percent of a county's population employed in the education industry is negatively correlated with economic growth. Combined with our results for human capital measures, this suggests that the benefits of education provided in a county are not internalized and significant spillovers occur.

The paper is organized as follows. In section 2, we briefly discuss the econometric specification of the growth regression equation implied by the neoclassical growth model on which our work is based and describe a cross-sectional variant of the 2SLS estimation method which we employ. In section 3, we describe the county-level data. In section 4, we present and discuss the empirical findings regarding the conditional convergence rates, followed by the analysis of the findings regarding growth determinants in section 5. We conclude in section 6 . In the data appendix we provide some more details on our data construction methods, variable definitions, and their measurements.

\section{Econometric Model Specification and Estimation}

The basic specification used here and in other cross-sectional growth regressions arises from the neoclassical growth model. ${ }^{10}$ The growth model implies that,

$$
\hat{y}(t)=\hat{y}(0) e^{-B t}+\hat{y}^{*}\left(1-e^{-B t}\right)
$$

where $\hat{y}$ is log of income per effective unit of labor (technology assumed to be labor augmenting), $t$ is the time period ( 0 being the initial time period), and $B$ is a nonlinear function of the economy's discount rate (average, subjective), population rate, and technological growth rate, as well as preference parameter(s). $B$ governs the speed of adjustment to the steady state. The $\hat{y}^{*}$ is the economy's steady-state log level of income

\footnotetext{
${ }^{10}$ Full details of the derivation of the baseline specification from the growth model are provided by Barro and Sala-i-Martin (1992).
} 
per effective unit of labor. From (1) it follows that the average growth rate of income per unit of labor between dates 0 and $T$ is,

$$
\frac{1}{T}(y(T)-y(0))=z+\left(\frac{1-e^{-B T}}{T}\right)\left(\hat{y}^{*}-\hat{y}(0)\right)
$$

where $z$ is the exogenous rate of technological progress and $B$ measures the responsiveness of the average growth rate to the gap between the steady state log of income per effective unit of labor and the initial value. Since effective unit of labor $(L)$ is assumed to equal $L e^{z t}$, we have $\hat{y}(0)=y(0)$.

From this model, growth regressions are obtained by fitting to the cross-sectional data with sample of economies $1, \ldots, N$, the equation

$$
g_{n}=\alpha+\beta y_{n 0}+\gamma^{\prime} x_{n}+v_{n}
$$

where $g_{n}$ is the average growth rate of per capita income for economy $n$ between years 0 and $T$ [i.e., $\frac{1}{T}(y(T)-y(0))$ ], $\alpha$ is a constant representing $\mathrm{z}, \beta=\left(\frac{1-e^{-B T}}{T}\right), x_{n}$ is a vector of variables that control for cross-economy heterogeneity in determinants of the steady-state, $\hat{y}^{*}, \gamma$ is a vector of coefficients on those variables, and $v_{n}$ is the error term assumed to have zero mean and finite variance.

Ordinary least squares (OLS) can then be used to infer the values of $\beta$ and $\gamma$ in (3) by simply regressing the growth rate over the time period on a constant, initial per capita income level and the initial values of conditioning variables. However, Evans (1997b) shows that for the consistency of OLS estimates, the data must satisfy highly implausible conditions, and argues that plausible departures from these conditions can produce large biases. Specifically, he demonstrates that unless (i) the dynamical structures of the economies examined have identical, first-order autoregressive representations, (ii) every economy affects every other economy symmetrically, and (iii) the set of conditioning variables controls for all permanent cross-economy differences, 
the OLS estimates of the speed of convergence are inconsistent-specifically they are biased downwards, underestimating the speed of convergence. ${ }^{11}$

Evans (1997b), therefore, proposes a 2SLS instrumental variables approach that consistently estimates the speed of convergence as well as the effects of conditioning variables. We use a cross-section variant of his method. The method consists of two stages. In the first stage we use instrumental variables to estimate the regression equation

$$
\Delta g_{n}=\omega+\beta \Delta y_{n 0}+\eta_{n}
$$

where

$$
\Delta g_{n}=\frac{\left(y_{n, T}-y_{n, 0}\right)}{T}-\frac{\left(y_{n, T-1}-y_{n,-1}\right)}{T},
$$

$\Delta y_{n 0}=y_{n 0}-y_{n,-1}, y_{n}$ is the logarithm of per capita income for county $n, \omega$ and $\beta$ are parameters, and $\eta_{n}$ is the error term. ${ }^{12}$ Given the sample period of the county-level data we use, we define

$$
\Delta g_{n}=\frac{\left(y_{n, 1998}-y_{n, 1970}\right)}{T}-\frac{\left(y_{n, 1997}-y_{n, 1969}\right)}{T}
$$

Next, define $\beta^{*}$ as the estimator obtained from equation (4). In the second stage, we take the estimate for $\beta^{*}$, multiply it by $y_{n 0}$ and then subtract the product from $g_{n}$. This yields a variable,

$$
\pi_{n}=g_{n}-\beta^{*} y_{n 0}
$$

which is then regressed on an intercept and the vector of variables, $x_{n}$, that are potential determinants of the cross sectional heterogeneity of the balanced growth paths.

The second-stage regression is of the form,

\footnotetext{
${ }^{11}$ These results, due to Evans (1997b), is reproduced in a referee's appendix which is available from the authors upon request.
} 


$$
\pi_{n}=\tau+\not x_{n}+\varepsilon_{n}
$$

where $\tau$ and $\gamma$ are parameters and $\varepsilon_{n}$ is an error term. This regression equation is estimated using the OLS, which yields a consistent estimator, $\gamma^{*}$.

What this two stage procedure essentially does is, in the first stage, it differences out any uncontrolled form of heterogeneity from the specification so that an omitted variable bias does not occur ${ }^{13}$ and then, in the second stage, it uses the resulting estimate of $\beta$ to recreate the component of a standard growth regression that would be related to the set of conditioning variables. ${ }^{14}$ This component can then be regressed on a constant and the conditioning variables, in "un-differenced" form, to estimate the effects of conditioning variables on balanced growth paths. This procedure ensures that none of the information contained in the levels of the conditioning variables is lost. ${ }^{15}$

\section{U.S. County-Level Data}

The data for this study were drawn from several sources. The majority of the data, however, came from the Bureau of Economic Analysis Regional Economic Information System (BEA-REIS) and U.S. Census data sets. ${ }^{16}$ The BEA-REIS data are largely based on the 1970, 1980 and 1990 decennial Census summary tape files, the

\footnotetext{
${ }^{12}$ As instruments, we used the lagged values, i.e., the 1969 values, of all the independent variables with the exception of Metro Area, Water Area, and Land Area. See the data appendix for details.

${ }^{13}$ The derivation of this equation (see Evans (1997b)) depends on the assumption that the conditioning variables are (approximately) constant during the time frame considered, allowing them to be differenced out. We are indebted to Nazrul Islam for pointing out that, while this is a reasonable assumption for many conditioning variables in the literature (e.g., an index of democracy for an international sample over 15 years), many of our county-level conditioning variables potentially vary significantly (e.g., the percent of the population employed in the communications industry over 28 years). To make sure that this did not introduce significant omitted variable bias into our estimations we ran the three first stage regressions for the full U.S., metro U.S. and non-metro U.S. with differenced values of all conditioning variables included as regressors. All point estimates of $\beta$ from the modified first stages fell within the 95 percent confidence intervals of the Evans method first stage estimates. As well, if the $\beta$ estimates are not significantly affected then neither are the second stage results (see below).

${ }^{14}$ We use a Hausman test as suggested by Greene (1997), as an additional aid in the determination of the appropriateness of this instrumental variable approach. Two separate tests were performed. The first test was run on the $\beta$ values and yielded an $m$ value of 134.6. The second test was run on the entire model and yielded an $m$ value of 1236.6. Indeed, both tests reject the null hypothesis at the $1 \%$ level, thereby suggesting that the OLS estimates are inconsistent.

${ }^{15}$ This is a point on which Barro (1997, p.37) has criticized panel data methods. As they rely on time series information, the conditioning variables are differenced. However, the conditioning variables often vary slowly over time so that the most important information is in the levels.
} 
1972, 1977, 1982 and 1987 Census of Governments and the Census Bureau's City and County Book from various years. All dollar variables are expressed in constant 1992 prices. Natural logs were used throughout the project. We exclude military personnel from the measurements of both personal income and population.

Our entire data set includes 3,058 county-level observations. ${ }^{17}$ Analyzing this data set in one group, however, would mean that we are implicitly imposing the assumption that all counties are identical, and therefore, it is meaningful to estimate a single rate of convergence parameter for the entire sample. However, as Evans (1998) and Brock and Durlauf (2001) emphasize, this assumption is not plausible for most data sets.

For example, according to Brock and Durlauf (2001), "Does it really make sense to believe that a change in the level of a civil liberties index has the same effect on growth in the United States as in the Russian Federation? ... [an] assumption of parameter homogeneity is particularly inappropriate in studying complex heterogeneous objects such as countries... the reporting of conditional predictive densities based on the assumption that all countries obey a common linear model may understate the uncertainty present when the data are generated by a family of models" (pp. 9-10). Similarly, Evans (1998, p. 296) argues that “... countries must surely have different technologies, preferences, institutions, market structures, government policies, and so forth.” These, according to Evans, represent important structural differences.

In the case of the U.S. counties, however, such heterogeneity is less likely to be important. Because we are focusing on one country the technologies available and used across U.S. counties are greatly similar, as are most of the institutional features and aspects of the market structure. In addition, many types of government policies (especially those enacted by the federal government) do not vary substantially across

\footnotetext{
${ }^{16}$ We thank Jordan Rappaport for kindly sharing with us some of the data used in this study.

17 The original data set contained 3,066 observations. Eight counties, however, were excluded from the data set for various reasons. Primarily, counties were excluded for lack of data. Examples of counties that fell into this category include counties in northern Alaska and some counties in Hawaii. Some data for these counties were simply not recorded as far back as 1970. Furthermore, in Virginia, some cities are themselves independent counties. If the data for these independent cities were available we let them stand as their own county. However, if the data were not available, then we tried to incorporate the independent city into the surrounding county. If that was not feasible, it was then dropped from the data set.
} 
counties. Therefore structural heterogeneity is less likely to be found in our data than in country-level samples.

Furthermore, the large number of observations allows us to detect whatever heterogeneity may still remain across the U.S regions. We have split the county leveldata into two sets of sub-samples, in addition to analyzing the entire data set. The first set separates the data into metro and non-metro counties. The second set separates the data into five regions. Given the unusually large number of observations we are able to conduct these sub-sample analyses without consequential sacrifice in degrees of freedom. As an additional control we have included in all regressions state dummies to capture differences between counties located in different states. This sort of breakdown of the data has previously not been practical when U.S. state-level data were used because of the extremely small number of observations remaining in the sub-samples, e.g. in our sample the New England region has 244 counties but only 11 states (and Washington D.C.).

In two sub-samples we have identified 867 of the 3,058 counties as metro and the remaining 2,191 as non-metro. In order to classify counties as either metro or non-metro we needed a decision rule that could be applied consistently across the entire sample. The rule chosen was simple: counties that contained cities with populations of 100,000 or more, or bordered such counties, were defined as metro counties. All other counties were classified as non-metro counties. ${ }^{18}$ Figure 1 shows this breakdown. We have also grouped counties into five regional sub-samples: New England, Great Lakes, Western Plains and Southeastern States. Table 1 and Figure 2 details how these regions were defined in terms of U.S. states and, therefore, counties as well.

The measure we use for personal income is that of the U.S. Bureau of Economic Analysis (BEA). ${ }^{19}$ The definitions that are used for the components of personal income for the county estimates are essentially the same as those used for U.S. national estimates. For example, the BEA defines "personal income" as the sum of wage and salary disbursements, other labor income, proprietors' income (with inventory valuation and

\footnotetext{
${ }^{18}$ In order to determine which cities had populations over 100,000, we used Census Bureau publication SU99-1, "Population Estimates for Cities with Populations of 100,000 and Greater."

19 The data and their measurement methods are described in detail in "Local Area Personal Income, 19691992” published by the BEA under the Regional Accounts Data, February 2, 2001.
} 
capital consumption adjustments), rental income (with capital consumption adjustment), personal dividend income and personal interest income. (BEA, 1994) "Wage and salary disbursements' are measurements of pre-tax income paid to employees. "Other labor income" consists of payments by employers to employee benefit plans. "Proprietors' income" is divided into two separate components-farm and non-farm. Per capita income for a county is defined as the ratio of this personal income measure for the county to the population of the county. We adjust the personal income measure to be net of government transfers.

In addition to the per capita income variable we also utilize 39 demographic conditioning variables. In Table 2 we provide the complete list of the variables we use in this study along with their definitions. In the table we also provide the source of each series as well as the period it covers. ${ }^{20}$

\section{Estimation Results: Analysis of Convergence Rates}

Figure 3 plots log of 1970 per capita income versus the growth rate of per capita income from 1970-1998 and includes a fitted line through the plots. A seemingly clear negative relationship presents itself in the table. This relationship represents evidence of absolute convergence (where all counties have identical balanced growth paths) and is worth noting although the primary focus of this paper is conditional convergence. In this section we report results confirming and quantifying convergence effects (both absolute and conditional) for U.S. counties. ${ }^{21}$

The estimates of $\beta$, the coefficient on the log of 1970 per capita income, are presented in Table 3 by regional and metro/non-metro classification. The speed of conditional convergence can be inferred from $\beta$. Along with the conditional OLS and 2SLS estimation results we also report in the table the estimated $\beta$ for the case where the

\footnotetext{
${ }^{20}$ A data appendix at the end of the paper describes and justifies in detail the construction/definition of metro and non-metro counties and regions. The appendix also details the BEA personal income data and why it was chosen over an alternative source (the U.S. Census Bureau database).

${ }^{21}$ In order to conserve on space we only report and discuss summary tables of convergence parameter and rate estimates. Likewise, in section 5 below, we only report and discuss summary tables of results for select conditioning variable. Detailed tables, including complete regression estimates by regional and metro/non-metro classifications for all conditioning variables, are included in the referee's appendix.
} 
growth equation (3) is estimated with the OLS excluding conditioning variables. ${ }^{22}$ Such a regression represents the hypothesis of absolute convergence. The point estimates for $\beta$ when conditioning variables are excluded are much smaller (e.g. -0.0068 (OLS) compared to -0.0174 (OLS) and -0.0345 (2SLS) for the entire sample) than their conditional counterparts. This suggests that the balanced growth paths are not the same across counties and, therefore, the determinants of the balanced growth path need be conditioned upon. ${ }^{23}$

Based on our estimates of $\beta$, Table 4 reports the asymptotic (conditional) convergence rate estimates along with their 95 percent confidence intervals. We report the asymptotic convergence rates for both OLS and 2SLS and across all different subsamples considered. Following Evans (1997b, footnote 17, p. 16), we use $c=1-(1+$ $T \beta)^{1 / T}$ to measure the asymptotic rate of convergence. These point estimates are reported in the 4th and 5th columns of Table 4. These confidence intervals are obtained in two steps. First, we obtained the end points of the confidence intervals by computing $\beta \pm$ $1.96 \times$ the estimate's standard error. Next, these endpoints were plugged into $c=1-(1+$ $T \beta)^{1 / T}$. If the lower value of $\beta$ 's confidence interval was less than $-1 / \mathrm{T}$, the higher value was equated to one.

According to Table 4, for the full sample of 3,058 counties the point estimate of the conditional convergence rate using the consistent 2SLS method is 6.82 percent and the coefficient is significant at the 1 percent level. Compare this to 2.40 percent using the inconsistent OLS method (also significant at 1 percent level). The OLS result is more in line with the results reported by Barro and Sala-i-Martin (1992), Mankiw, et al. (1992) and Sala-i-Martin (1996). The difference between the two point estimates is nearly 300 percent suggesting that the use of OLS introduces a substantial bias. As well, the

\footnotetext{
${ }^{22}$ Estimating the unconditional case with 2SLS would not make sense because the first stage would difference out all uncontrolled for heterogeneity and, therefore, the second stage would estimate the $\beta$ with an assumption of different balanced growth paths. In other words, the $\beta$ would be identical to the one we report with 2SLS assuming conditional convergence.

${ }^{23}$ It is, perhaps, worth noting that the unconditional $\beta \mathrm{s}$, while drastically smaller, are still negative and significant at the 1 percent level when full sample is used and when either the metro or the non-metro sample is used. So we cannot reject absolute convergence, but only infer that it is very slow. Take the point estimate on the full sample: -0.0068 . This implies and absolute rate of convergence of about 0.7 percent, in turn implying that economies cover half the present gap between themselves and the wealthiest economy in just under a century.
} 
difference is economically significant in a striking fashion. If the OLS point estimate is the true rate of convergence, counties will halve the present gap between their per capita income level and their balanced growth path level in 31-32 years. If the 2SLS estimate is the true convergence rate, halving the gap will take only 12-13 years.

The conclusion is nearly identical in the cases where we split the sample into metro and non-metro counties. For the metro-counties the 2SLS point estimate of the asymptotic convergence rate is 7.49 percent while the OLS point estimate is 1.65 percent. For the non-metro counties the 2 SLS point estimate is 6.42 percent while the OLS method yields 2.78 percent. All of these estimates are statistically significant at the 1 percent level. The overlap between the (narrow) confidence intervals suggests that any difference between the metro and non-metro counties in terms of their convergence rates is small when we consider the full U.S. sample. Thus we find that, regardless of whether or not we look at metro or non-metro areas, the consistent estimate of the rate of convergence across the U.S. counties is in the range of 6 to 8 percent. $^{24}$

Now consider the variation in the asymptotic convergence rate by region. For all counties together we find that the convergence rate is the lowest amongst the counties located in the New England and Plains regions with 3.78 percent and 3.83 percent respectively, followed by 4.48 percent for the counties located in the Great Lakes states. We find the highest rates of asymptotic convergence of 7.78 percent and 10.33 percent, respectively, amongst the counties located in the Western and Southern regions. ${ }^{25}$

\footnotetext{
${ }^{24}$ One might question these results-in particular the estimates of the convergence rates-due to the differencing of variables during the first stage of our 2SLS estimation procedure. Panel data estimation strategies that difference the variables to remove fixed effects tend to report convergence rate estimates of greater magnitude than otherwise. For example, Islam (1995, Table 3 and 4), examining international data, reports estimates of conditional convergence rates between 4 and 5 percent (even higher for OECD countries). However, Barro (1997, pp. 36-42 and Table 1.3) demonstrates that large standard errors accompany differencing of the conditionals. This is because the conditioning variables most often do not change much over relevant time periods and differencing them tends to emphasize measurement error over the correct information contained in the level, biasing convergence rate estimates upward. However, this criticism is not applicable to our results for two reasons. First, Evan's (1997b) method produces consistent estimates while OLS without differencing does not. Second, the first stage of 2SLS does not include conditionals-differenced or otherwise-so we do not sacrifice degrees of freedom in exchange for little cross-sectional information, nor do we emphasize measurement error in the regression.

${ }^{25} \mathrm{We}$ explored the possibility of a correlation between regional convergence rates and the average rate of economic growth over our sample period. Using per-capita Gross State Product (GSP) there was no apparent correlation. The fastest growing region (on average) - New England (6.14 percent) - had the lowest asymptotic convergence rate (3.78 percent). The slowest growing region - Great Lakes (5.32 percent) - had the median asymptotic convergence rate (4.48). What this suggests is that the "conditional"
} 
Comparing the estimation results when regional samples are broken down into metro and non-metro subsamples, we find the biggest difference in the Western regions, where the conditional convergence rate of the metro countries is 12.53 percent, while for the non-metro counties we obtain a conditional convergence rate of 7.59 percent. Thus, in the western states the speed of convergence of the metro counties exceeds the convergence rate of the non-metro counties. The results indicate a substantial difference between the metro and non-metro counties in the Southern states also. However, here we find that conditional convergence rate of the non-metro countries, 10.61 percent, exceeds the convergence rate of the metro counties, 6.78 percent.

For the remaining three regions, the difference in the asymptotic convergence rate between the metro and non-metro counties is less remarkable. In the Great Lakes region, the asymptotic convergence rates of metro and non-metro counties are 5.92 percent and 4.00 percent respectively. In the New England region they are 3.89 percent and 4.22 percent respectively, and in the Plains they are 3.96 percent and 5.11 percent respectively.

\section{Estimation Results: Analysis of Balanced Growth Path Determinants}

As discussed in section 4, we are unable to reject the conditional convergence hypothesis and, therefore, the effects of conditioning variables are interpreted as influences on the height of an individual economy's balanced growth path. ${ }^{26}$ In our regressions the coefficients indicate the effect of these variables on the average growth rate of per capita income indirectly via the position of the balanced growth path. Given that position, the average growth rate increases (if the balanced growth path is higher) or decreases (if the balanced growth path is lower) as a result of the deviation of the economy from its individual balanced growth path and the convergence effect towards that path.

\footnotetext{
in conditional convergence is quite important, e.g., New England's balanced growth path may be high enough that it continued to grow faster than poorer regions with higher convergence rates.

${ }^{26}$ If convergence were to be rejected then the coefficients would be better interpreted as influences on individual economies' balanced growth rates. Evans (1997b) details the interpretation of these parameters when convergence is not rejected (allowing for evaluation of different exogenous growth theories) and when convergence is rejected (allowing for evaluation of different endogenous growth theories).
} 
In this section we focus on these indirect effects of the conditioning variables on economic growth rates. The conditioning variables we choose to discuss here are grouped into educational variables, government employment variables and industry variables. (Again, Table 2 gives descriptions and sources of these and all of the other conditioning variables.) In each case we first discuss the results for the entire sample. Then we address the possibility of regional heterogeneity in the effects, as well as differences that arise when considering either metro or non-metro counties separately.

\section{Educational Attainment}

As Table 2 indicates, our data include eight different variables measuring the educational attainment of the U.S. counties. We will focus on four of these variables: the percent of the population with (i) 11 years education or less, (ii) high school diploma, (iii) some college education, and (iv) bachelor degree or more. ${ }^{27}$ Table 5 reports the coefficient estimates of the four selected educational attainment variables in a compact form. ${ }^{28}$ To preserve space we only focus on the 2 SLS results, although we report the OLS estimation results as well. ${ }^{29}$

The point estimate of the coefficient on the percent of the population with 11 years of education or less is -0.0222 and is significant at the 1 percent level. This is not surprising. The greater percent of an economy's population without the remedial mathematics, writing and communication skills—not to mention the minimum discipline and social behavior - necessary for a high school diploma, the lower the rate of growth. Passing that threshold, the coefficient for the population achieving (but not surpassing) a

\footnotetext{
${ }^{27}$ The remaining four educational attainment variables are the number of students enrolled in the public elementary schools, public nurseries, private elementary schools, and the private nurseries. We get mixed results in terms of the statistical significance of these variables. Although two of them attain statistically significant values, none of the coefficients have quantitative economic significance. The point estimates of all coefficients are zero at four-digit precision.

${ }^{28}$ One reader suggested that we should explore interactions of initial income and schooling variables. The results here focus on the variables entered by themselves in linear form. However, the reader's suggestion is an important avenue to explore for schooling. For example, schooling may affect the ability of an economy to converge. Similar hypotheses could be made concerning government variables. However, we choose to pursue this avenue in future research because (a) the relative (to a sample of nations) income homogeneity across the U.S. and human capital mobility could mitigate these effects significantly and (b), importantly as a practical matter, the choice of the interaction form (e.g., linear-linear, linear-quadratic, quadratic-quadratic, etc.) is a project beyond the scope of this paper.

${ }^{29}$ In section 5 we focus on 2 SLS results exclusively although OLS estimates are also included in all subsequent tables where we report the estimated effects of the selected conditioning variables.
} 
high school diploma or equivalent has a point estimate of about 0.0097 percent (significant at the 1 percent level).

While the above is not surprising, the results for the percent of the population with some college, but not a bachelor's degree, might be. The coefficient is -0.0025 , but it is not statistically significant. In fact, the sign of the coefficient is different for metro $(-0.0044)$ and non-metro $(0.0032)$ counties. It is in neither case significant, however. Compare this to the (perhaps-more-expected) result on the coefficient for the percent of the population with at least a bachelor degree (0.0732 and significant at the 1 percent level). A possible interpretation of these findings concerns the opportunity cost of education. College education ostensibly involves a benefit, in the form of increased skills/productivity for the individual, but it also involves a cost in the form of wages foregone. The results might lead one to believe that a college education of 4 years represents a positive net return to an individual, while the net return on a two-year degree is questionable.

However, Kane and Rouse (1995) and Surette (1997) report that the estimated return to 2-year degree education is positive and equals about 4-6 percent and 7-10 percent, respectively. Neither of these studies, however, uses county-level data. In addition, what these studies do not take into account, which our estimates presumably do, is the social return, rather than the private return to the individual. Both studies look at individuals' costs (tuition, wages foregone, experience foregone, etc.) and benefits (wage premiums) while we consider their effect on the average growth of an economy over a 30 -year period. What we might be seeing in our results, therefore, is a questionable social return (as opposed to individuals' returns) to an associate's degree-level education. This is potentially an important finding for policy-makers. As Kane and Rouse (1995, p. 600n) note, “Twenty percent of Federal Pell Grants, 10 percent of Guaranteed Student Loans, and over 20 percent of state expenditures for postsecondary education, go to community colleges." If the social return to college education that does not end with a bachelor degree level is not positive, then large subsidies must be reconsidered or restructured as to encourage a bachelor degree or more as the final outcome for recipients. 
Comparing the metro and non-metro counties, we find that the coefficient on the "bachelor degree or more" variable for the non-metro counties is 0.0574 while for the metro counties it is 0.1138 (both significant at the one percent level). Thus, it appears that bachelor degree or more-level human capital in the metro area is twice as productive in terms of its contribution to income growth as the same human capital in the non-metro area.

Our results are usefully comparable to other empirical studies on economic growth, such as those of Barro (1991) and Barro and Sala-i-Martin (1992). Barro (1991) uses enrollment rates for primary and secondary education as a proxy for human capital accumulation. He finds that these variables have a positive and significant effect in growth regressions. Barro and Sala-i-Martin (1992) confirm that these variables are important for estimating the conditional convergence. Our variables have two advantages. First, the enrollment rates, as Barro (1991, pp. 420-421) recognizes, are perhaps best interpreted as flows rather than stocks, while our variables are more clearly indicative of stocks of education (human capital) in an economy's population. Second, the greater gradation of educational levels allows us to more finely examine the net social return for different levels of education.

\section{(b) Size of the Public Sector}

Does "big government" foster or hinder economic growth? While broad and simplistic, this query expresses a basic and important concern about the possibility of government action improving or harming an economy. Our data include three separate conditioning variables capturing the size of the public sector at three different levels of the government. These are the percents of a county's population employed by (i) the federal government, (ii) the state government, and (iii) local government. These provide a unique view on the effect of the extent of the public sector on economic growth.

The issue of whether or not government fosters or hinders economic growth has been explored widely. ${ }^{30}$ Using the framework of the neoclassical growth model and

\footnotetext{
${ }^{30}$ There are also many studies that focus on the level of income rather than the growth rate. Slemrod (1995) provides an exceptional review of these studies and their relation to the growth rate studies. He notes that (p. 399) the "level studies primarily try to explain G [the extent of government] and include Y [income] as one explanatory variable; that $\mathrm{G}$ might affect $\mathrm{Y}$ is ignored, ... The growth studies try to explain
} 
examining a cross section of countries, Barro (1991) finds that a large public sector is growth hindering. Easterly and Rebelo (1993) find in cross-country data that public investment in transportation and communication are positively associated with economic growth but that any links between growth and other fiscal variables is fragile. ${ }^{31}$ Evans (1994) reports that government activities, with the exception of expenditures on education services, are either unproductive or affect growth negatively. More recently, Folster and Henrekson (2001) study a panel data of wealthy nations and, after conducting a battery of robustness tests, conclude that there is a strong relation between high public expenditures and lower economic growth. ${ }^{32}$

All these studies, however, use various government expenditure variables to capture the size and the scope of government activities. We, in contrast, use the percent of a county's population employed by the federal, state, and local governments. These variables offer several advantages over previous studies.

First, separate measures for federal, state, and local governments allow us to explore how the relationship between government prevalence and growth differs at the three levels of decentralization. For example, a reasonable belief may be that local governments can more closely ascertain and respond to the unique needs of its constituents. In addition, the productivity of government expenditure may be expected to decrease as it gets more centralized. Our analysis can address such a hypothesis, whereas previous studies cannot.

Second, the use of three separate measures of government activity to some extent helps us avoid the problems of interpreting coefficients across geographical units when externalities are present. For example, a state government may operate educational

the growth rate of $\mathrm{Y}$... and often include $\mathrm{G}$ as one of the explanatory variables. The possibility of a structural relationship determining $\mathrm{G}$ is often completely ignored." To keep the discussion in this paper focused we confine it to growth rate studies and, in particular, those based on the neoclassical growth model. For other approaches see Gramlich (1994) and Slemrod (1995).

${ }^{31}$ See also Aschauer (1989, 2000 and 2001).

${ }^{32}$ An important paper by Levine and Renelt (1992) has shown that conclusions from cross-country regressions may not be robust to small changes in the conditioning variable set. In particular, "broad array of fiscal-expenditure variables... considered by the profession, are not robustly correlated with growth" (p. 943). The 2SLS approach theoretically will give us consistent estimators for conditioning variable coefficients regardless of the specific set included. Despite this, after running the 2SLS regressions for the entire sample with all conditioning variables, we ran the regressions not including the conditioning variables that initially had coefficient point estimates of less than 0.0000 in absolute value and found that 
institutes (at a cost detectable in a growth regression coefficient) only to have many of the students, upon graduation, leave to live and work in other states (creating benefits not detectable in a growth regression coefficient). In general one would expect externalities to be less important for state rather than federal government, and even less important for local rather than state government. As a further example, a negative coefficient on the federal government measure might be questioned because the federal services are spread across the nation, while a negative coefficient on a local government measure is immune from such a suspicion.

Third, the variables measuring the percent of population employed allow for a fundamentally different and complementary way of conceptualizing the extent of government's involvement in the economy, as opposed to those of other studies. As with the case of educational attainment variables, the percent of a population employed by government can be interpreted as a stock of government activities/roles producing a flow of services, while government expenditures are the flow of services from those activities/roles. Moreover, the percent of a population employed gives a direct perspective on to what extent government is involved, i.e. how much of labor force activity is directed by government, rather than simply how much government spends. ${ }^{33}$

Table 6 summarizes the estimated coefficients on extent of public sector variables in a compact form. We find a negative relationship between the percent of the population employed in the public sector and the rate of economic growth. The effect is negative and statistically significant regardless of whether one considers federal, state or local government. Furthermore, there is no clear pattern of the public sector having less of a negative effect at increasingly more decentralized levels. The coefficients for the federal, state and local employee percent of the population variables are $-0.0222,-0.0163$, and 0.0204 respectively. These point estimates are all significant at the 1 percent level.

While these findings suggest that an increased public sector hinders economic growth via distortion of incentives and diversion of resources, another possible interpretation is that non-government wage growth simply outpaces government wage 
growth, and this drives the result given when personal income per capita serves as the dependent variable. ${ }^{34}$ In order to explore this alternative explanation we have assembled government and non-government wage growth data for the 1970-1998 period. At the state and federal level, Table 7 demonstrates that across the entire sample (panel (a)) government wages outpace non-government wages in approximately 45 percent of counties. At the local level, government wages grew faster in over 70 percent of counties. Relative sluggishness of government wages at the state and federal levels is dominated by wage growth rates in the metro counties (panel (b)). For the non-metro counties, which constitute a vast majority of 2,196 counties panel, government wages outpaced non-government wages in nearly 50 percent of cases (panel (c)).

As such, if a relatively sluggish growth of government wages story were important then we would expect to find the estimated coefficients smaller for metro counties than for non-metro counties. This we do see. The coefficient estimates for the regression including only metro counties are $-0.0318,-0.0263$ and -0.0230 for federal, state and local governments respectively. For non-metro counties the corresponding estimates are $-0.0171,-0.0071$ and -0.0128 . (All the estimates are significant at the 10 percent level or better.) However, note that in metro and non-metro counties the coefficient on percent of population employed by local government is negative despite the fact that those wages outpaced non-government wages in a majority of counties in both cases. So, at least at the most decentralized level of government, a relatively sluggish government wage growth story is unable to account for the negative effect. Indeed, we estimate a negative effect despite the relatively fast growth of government wages.

The above, combined with the fact that federal and state coefficients are negative and significant for non-metro counties (where there seems to be little evidence that nongovernment wages outpace government wages in any substantial way), leads us to conclude that extent of the public sector at all levels distorts incentives and resource

\footnotetext{
${ }^{33}$ Of course the conceptualizations are not mutually exclusive. Government spends on wages so that part of the labor force is involved in government actions, for example. This overlap is what makes the two types of variables complementary.

${ }^{34}$ We thank Paul Rubin for bringing this idea to our attention.
} 
allocations in a way that impedes an economy to an extent above and any productive contributions.

\section{(c) Industry Composition Effects}

Our data consist of 16 industry-level variables, each measuring the percent of the population employed in the given industry. These industries include agriculture, communications, construction, finance, insurance and real estate, manufacturing of durables, manufacturing of non-durables, mining, retail, business and repair services, educational services, professional and related services, health services, personal services, entertainment and recreational services, transportation services, and wholesale trade.

Interpreting correlations between personal income growth rates and a percent of county population employed in a given industry is difficult. Their interpretation below, therefore, is of a more speculative nature. Moreover, we focus on three industry categories that were of interest, had significant estimated effects, and about which we felt our speculations had reasonable foundations: (i) finance, insurance and real estate services, (ii) educational services and (iii) entertainment and recreational services. The coefficient estimates of these variables are summarized in Table 8 for the full sample and by regional and metro/non-metro breakdowns.

\section{Finance, Insurance and Real Estate Services}

We find a positive relationship between the percent of the population employed in finance, insurance and real estate services and economic growth across U.S. counties. The point estimate of the coefficient for the entire sample is 0.0778 and is significant at the 1 percent level. The correlation is similar whether one considers the metro $(0.0633)$ or non-metro (0.0778) sub-sample. A possible reason for this finding is the link between financial intermediation and economic growth. Similar findings are reported by Rousseau and Wachtel (1998) who use data from 1870 to 1920 to document quantitatively important links between financial intensity and per capita output level in five OECD countries.

Our findings may be interpreted as offering empirical support to the models of Greenwood and Jovanovic (1990) and King and Levine (1993). In the model of 
Greenwood and Jovanovic (1990) financial development leads to economic growth because, as financial intermediation become more prevalent, agents gain confidence in intermediaries' ability to allocate funds profitably, leading to a better matching of funds with productive investments and, consequently, to greater growth. In King and Levine's (1993) model greater intermediation enhances information gathering potential and allows for funding of productive investment by less-established firms that otherwise would remain un-funded. Our findings are consistent with both these interpretations but cannot discriminate between them.

\section{Educational Services}

Unlike the educational attainment levels of a population, the percent of the population providing educational services is negatively correlated with the rate of economic growth in our full sample (point estimate -0.0334 , significant at 1 percent level). This result appears to stem mainly from the metro counties where the point estimate is -0.0513 and significant at the 1 percent level. The coefficient for non-metro counties is not statistically significant.

A likely explanation for this correlation is that the benefits of education provided in a county are not entirely internalized by the county itself. For example, many college and university graduates do not remain within the county where their colleges and universities are located. The finding discussed in section $5 \mathrm{a}-$ that the stock of human capital positively affects economic growth-is silent as to where the population members of a county accumulated that stock. Tamura (1991) points out that there is "a desire for labor mobility to areas where the external effect is operative" (p. 523). For example, individuals may attend a college in counties where human capital is relatively easy to accumulate and then move to other counties as they join the workforce. This would be

particularly true for metro counties where the great majority of colleges, universities, and other higher education institutions are located. Indeed, we find that the negative relationship between the percent of population employed in the educational service and economic growth primarily holds for the metro counties. For the non-metro counties this 
relationship is either smaller in comparison to the metro counties, or is statistically insignificant. $^{35}$

\section{Entertainment and Recreational Services}

The estimated effect of this variable on economic growth is positive and significant at the 1 percent level in the full sample with a point estimate of 0.0477 . The effect is larger in metro counties, but significant in non-metro counties as well. (The point estimates are 0.0609 and 0.0399 respectively). This effect is a potentially important one. First, to put it in perspective, it is larger (in absolute value) than the estimated effect of the public sector size variables for any level. Second, Costa (1997, Table 1) reports that, as a percent of households' budgets, recreation expenditures rose from 1.9 percent around 1890, to 4.5 percent in 1950, and then to 5.6 percent in 1991. Thus, entertainment and recreation services comprise an increasingly large segment of the U.S. economy.

The above finding might be capturing the increase in economic activity that is fostered by the presence of gambling casinos and professional sports teams and their stadiums. For example, Siegfried and Zimbalist (2000, p. 114) report that by 2005 there will be 95 professional sports stadiums having been constructed since 1990, and more than $\$ 27.1$ billion will be spent on these stadiums. ${ }^{36}$ Similarly, Eadington (1999, p. 173) notes that that gross gaming revenues had reached $\$ 540$ billion in 1997 . In addition, studies such as Anderson (1997) and Walker and Jackson (1998), have documented economic growth stimulated by the introduction of casino industries.

\section{Concluding Remarks}

We use county-level data from 3,058 U.S. counties to study economic growth and measure the speed of convergence. County-level data are particularly valuable for

\footnotetext{
${ }^{35}$ Another explanation for the finding of the negative relationship between the educational service employment percentage and the economic growth is a possible bureaucratic over-expansion of the public school systems as suggested by Marlow (2001), and frequently mentioned in media discussions. Examining California school districts for primary and secondary schools, however, Marlow finds that an increase in non-teacher educational workers decreases SAT scores and increases dropout rates; an increase in the number of teachers has no statistically significant effect; and an increase in the size of administrative staff increases the SAT scores and decreases dropout rates. Also, if bureaucratic over-expansion in the public school systems was the explanation, then it is not clear why would there be systematic differences between metro and non-metro counties.

${ }^{36}$ By "professional sport" Siegfried and Zimbalist mean the NHL, the MLB, the NFL, and the NBA.
} 
studying convergence because they allow us to study a sample with substantial homogeneity and mobility of capital, labor and technology without sacrificing the benefits of a large number of cross-sectional units. Our data set allows us to include nearly 40 different conditioning variables to capture whatever heterogeneity might exist across counties and to assess how those variables affect the balanced growth paths.

We report estimates from standard OLS and a 2SLS instrumental variables method. We report the estimates for the entire data set as well as for its subsets, which include metro counties, non-metro counties, and counties grouped into five regions.

We find that (i) while the OLS yields estimates of the asymptotic convergence rate just above 2 percent, the 2 SLS method consistently estimates a convergence rate between 6 and 8 percent. This difference is economically significant in that it represents a difference in the half-life of the gap between present levels of income and the balanced growth path of 32-33 years (6.82 percent convergence rate) versus 12-13 years $(2.40$ percent convergence rate) respectively. We also find that (ii) the convergence rates are quite variable: the counties in the Southern states converge at a rate that is more than two and half times faster than the counties located in the New England states. In addition to convergence rates we find that (iii) the extent of the public sector at all levels (federal, state and local) negatively affects economic growth and there is no evidence of the public sector becoming more productive at more decentralized levels; (iv) the relationship between a population's educational attainment and economic growth is nonlinear depending on the years of education considered (positive for up to high school, insignificant or even negative for between high school and associates degree levels, and then positive for further years of schooling); and (v) a large presence of finance, insurance and real estate industry, as well as the entertainment industry is positively correlated with economic growth while the percent of a county's population employed in the education industry is negatively correlated with economic growth. 


\section{Data Appendix}

\section{A) Construction of Metro and Non-Metro County Level Data}

A population size of 100,000 was chosen as the minimum threshold for metro counties for three reasons. ${ }^{37}$ First, the data available was limited with respect to reporting smaller city sizes. Second, the BEA uses the 100,000-figure as the minimum necessary for classifying a locality as a county for the purpose of processing the county (or countyequivalent) source data. ${ }^{38}$ Third, it was felt that cities with smaller populations would not provide the spillover effects into the surrounding counties needed to justify the decision rule. Note that these populations are of the actual cities and they do not include the populations in the surrounding metropolitan areas. For example, the population for the city of Atlanta is only the population within city limits and not Fulton County - the county where Atlanta resides. Additionally, this decision rule extends beyond state boundaries. For example, Cincinnati is located in southwestern Ohio. The Cincinnati metro area, however, extends well beyond southwestern Ohio into northern Kentucky and southeastern Indiana. Therefore, when the metro counties are viewed on aggregate it is without regard to state boundaries.

This decision rule also errs on the side of conservatism. While it may be the case that metropolitan areas with very large populations expand out beyond what our classification would indicate, the majority of the overall population for those metropolitan areas has been captured. Additionally, by erring on the side of conservatism we can be more confident that the metro counties are more homogenous than they might otherwise be. For example, since we are unable to further sub-divide counties, the farthest reaches of a metropolitan area may contain a county where only a small portion of the population would be classified as belonging to that metropolitan area. If we were to include that entire county as a metro county we would be incorrectly classifying the entire county.

Our decision to err on the side of conservatism, might impact our final analysis results in the following way. The metro county analysis results will be slightly

\footnotetext{
${ }^{37}$ In order to determine which cities had populations over 100,000, we used Census Bureau publication SU99-1, "Population Estimates for Cities with Populations of 100,000 and Greater."
} 
understated since it may be excluding small populations on the outskirts of metropolitan areas and our non-metro county analysis results may be slightly over stated for the exact opposite reason-it will be including a population that should otherwise be categorized as metro.

It is for this reason that we chose not to utilize the metropolitan statistical areas (MSA), as defined by the Office of Management and Budget (OMB). An example will help demonstrate the difference. The MSA for Atlanta, Georgia, as defined by the OMB consists of the following 20 counties: Barrow, Bartow, Carroll, Cherokee, Clayton, Cobb, Coweta, DeKalb, Douglas, Fayette, Forsyth, Fulton, Gwinnett, Henry, Newton, Paulding, Pickens, Rockdale, Spalding, and Walton. ${ }^{39}$ Our metro classification for Atlanta consists of the following 10 counties: Carroll, Cherokee, Clayton, Cobb, Coweta, DeKalb, Fayette, Forsyth, Fulton and Gwinnett. The 10 counties included in our metro region contain the largest portion of the metropolitan area, in terms of population. It should be noted that our metro classification contains most of the same MSAs as the OMB's classification. The counties that constitute those regions, however, are different, as demonstrated above. As previously noted, our classification tends to have fewer counties attached to a particular metropolitan area providing, we believe, a more homogenous population.

\section{B) Construction of the Regional County Level Data}

To perform the second set of sub-sample analysis, we have separated the sample into five regional subgroups. These regions are New England, Great Lakes, Western, Plains, and Southeastern states. Table 1 and Figure 2 identifies our regional beak-down of the individual U.S. states. The limiting constraint on further increasing the regions was the number of counties within some of the States. For example, a few of the states in the New England Region have less than ten counties. Given the number of independent variables, it was necessary to increase the size of the regions in order to increase the overall number of observations. An attempt was made to group states that were closely

\footnotetext{
${ }^{38}$ See "Local Area Personal Income, 1969-1992," Bureau of Economic Analysis, Regional Accounts Data, February 2, 2001, p. 1.

${ }^{39}$ The city of Atlanta is located in Fulton County.
} 
related to each other as much as possible in terms of their economic and socio-economic characteristics.

Given the data constraints, it was necessary to use an interpolation procedure for some variables. ${ }^{40}$ In this study we cover the $1970-1998$ period. However, in order to implement the Evans' (1997a, 1997b) 2SLS estimation method as described in section 2, we needed to have available data values for 1969 and 1997. We used a linear interpolation method to generate these missing observations. It should be noted that none of the data relating to income and population variables were generated by this method, as they were available from BEA-REIS on a yearly basis for the entire period covered. The Census data variables, which were available in 1970, 1980 and 1990, were interpolated in order to generate the 1969, 1997, and 1998 values.

\section{C) Measurement of Per Capita Income}

Because of the critical importance of the income variable for the study of growth and convergence, we want to address its measurement in some detail. Two options were available to us for the construction of the county-level per capita income variable: (1) Census Bureau database, and (2) BEA-REIS database.

Income information collected by the Census Bureau for states and counties is prepared decennially from the "long-form" sample conducted as part of the overall population census (BEA, 1994). This money income information is based on the selfreported values by Census Survey respondents. An advantage of the Census Bureau's data is that they are reported and recorded by place of residence. These data, however, are available only for the "benchmark" years, i.e., the years in which the decennial Census survey is conducted.

The second source for this data, and the one chosen for this project, is personal income as measured by the Bureau of Economic Analysis (BEA). ${ }^{41}$ The definitions that are used for the components of personal income for the county estimates are essentially the same as those used for the national estimates. For example, the BEA defines

\footnotetext{
${ }^{40}$ Sala-i-Martin (1996) as well as others have used such a procedure. We should note that given the crosssection nature of our data, the use of interpolated series do not introduce problems of the type reported by Dezhbakhsh and Levy (1994), who focus on the periodic time series properties of the interpolated data.

${ }^{41}$ The data and their measurement methods are described in detail in "Local Area Personal Income, 19691992” published by the BEA under the Regional Accounts Data, February 2, 2001.
} 
"personal income" as the sum of wage and salary disbursements, other labor income, proprietors' income (with inventory valuation and capital consumption adjustments), rental income (with capital consumption adjustment), personal dividend income and personal interest income. (BEA, 1994) “Wage and salary disbursements’ are measurements of pre-tax income paid to employees. "Other labor income" consists of payments by employers to employee benefit plans. "Proprietors' income" is divided into two separate components-farm and non-farm. Per capita income is defined as the ratio of this personal income measure to the population of an area. ${ }^{42}$

The BEA compiles data from several different sources in order to derive this personal income measure. Some of the data used to prepare the components of personal income are reported and recorded by place of work rather than place of residence. Therefore, the initial estimates of these components are on a place-of-work basis. Consequently, these initial place-of-work estimates are adjusted so that they will be on a place-of-residence basis and so that the income of the recipients whose place of residence differs from their place of work will be correctly assigned to their county of residence.

As a result, a place of residence adjustment is made to the data. This adjustment is made for inter-county commuters and border workers utilizing journey-to-work (JTW) data collected by Census. For the county estimates, the income of individuals who commute between counties is important in every multi-county metropolitan area and in many non-metropolitan areas. The residence adjustment estimate for a county is calculated as the total inflows of the income subject to adjustment to county $i$ from county $j$ minus the total outflows of the income subject to adjustment from county $i$ to county $j$. The estimates of the inflow and outflow data are prepared at the Standard Industrial Classification (SIC) level and are calculated from the JTW data on the number of wage and salary workers and on their average wages by county of work for each county of residence from the Population Census.

\footnotetext{
${ }^{42}$ The BEA's estimates of personal income reflect the revised national estimates of personal income that resulted from the 1991 comprehensive revision and the 1992 annual revisions of the national income and product accounts. The revised national estimates were incorporated into the local area estimates of personal income as part of a comprehensive revision in May 1993. In addition, the estimates incorporate source data that were note available in time to be used in the comprehensive revisions. For details of these revisions, see "Local Area Personal Income: Estimates for 1990-92 and Revisions to the Estimates for 1981-91," Survey of Current Business 74 (April 1994), 127-129.
} 
Obviously, metro areas and the surrounding counties will have a higher proportion of "cross-county" commuters. By using our classification system for metro counties we alleviate any problems that might arise with the BEA's adjustment process since we are grouping these metro counties into one single observation unit. Moreover, the classification scheme we have in place should pick up the majority of cross-county commuters. 


\section{References}

Anderson, Arthur \& Co. (1997), Economic Impacts of Casino Gaming in the United States, Volume 2: Micro Study (Washington, D.C.: American Gaming Assoc.)

Aschauer, David A. (1989), "I Public Expenditure Productive?" Journal of Monetary Economics 23, 177-200.

Aschauer, David A. (2000), "Do States Optimize? Public Capital and Economic Growth." Annals of Regional Science 34, 343-363.

Aschauer, David A. (2001), "Output and Employment Effects of Public Capital," Public Finance and Management 1

Barro, Robert J. (1991), "Economic Growth in a Cross Section of Countries," Quarterly Journal of Economics 106, 407-443.

Barro, Robert J. (1997), Determinants of Economic Growth: A Cross-Country Empirical Study (Cambridge, MA: MIT Press).

Barro, Robert J. and Xavier Sala-I-Martin (1991), "Convergence Across States and Regions," Brookings Papers on Economic Activity 1, 107-158.

Barro, Robert J. and Sala-i-Martin, Xavier (1992), “Convergence," Journal of Political Economy 100, 223-251.

Brock, William A. and Steven N. Durlauf (2001), "Growth Empirics and Reality," University of Wisconsin, Madison, Working Paper 2024.

Cass, David (1965), "Optimum Growth in an Aggregative Model of Capital Accumulation," Review of Economic Studies 32, 233-240.

Costa, Dora L. (1997), “Less of a Luxury: The Rise of Recreation Since 1888," NBER Working Paper 6054, June.

Dezhbakhsh, Hashem and Daniel Levy (1994), "Periodic Properties of Interpolated Time Series," Economics Letters 44, 221-228.

Durlauf, Steven N. (2001), "Manifesto for a Growth Econometrics," Journal of Econometrics 100, 65-69.

Durlauf, Steven N. and Danny Quah (1999), "The New Empirics of Economic Growth," in John Taylor and Michael Woodford, eds, Handbook of Macroeconomics (Amsterdam: North Holland).

Eadington, William R (1999), "The Economics of Casino Gambling," Journal of Economic Perspectives 13, 173-192.

Easterly, William and Sergio Rebelo (1993), "Fiscal Policy and Economic Growth," Journal of Monetary Economics 32, 417-458.

Evans, Paul (1996), "Using Cross-Country Variances to Evaluate Growth Theories," Journal of Economic Dynamics and Control 20, 1027-1049.

Evans, Paul (1997a), "How Fast Do Economies Converge?" Review of Economics and Statistics 36, 219-225.

Evans, Paul (1997b), "Consistent Estimation of Growth Regressions," unpublished manuscript, available at http://economics.sbs.ohiostate.edu/pevans/pevans.html.

Evans, Paul (1998), "Using Panel Data to Evaluate Growth Theories," International Economics Review, Volume 39, No. 2 (May), 295-306.

Evans, Paul and Georgios Karras (1994), "Are Government Activities Productive? Evidence from a Panel of U.S. States," Review of Economics and Statistics, Volume LXXVI, No. 1, 1-11. 
Evans, Paul and Georgios Karras (1996), "Convergence Revisited," Journal of Monetary Economics 37, 249-265.

Folster, Stefan and M. Henrekson (2001), "Growth Effects of Government Expenditure and Taxation in Rich Countries," European Economic Review 45, 1501-1520.

Gramlich, Edward M. (1994), "Infrastructure Investment: A Review Essay," Journal of Economic Literature 32, 1176-1196.

Ghiglino, Christian and Gerhard Sorger (2002), "Poverty Traps, Indeterminacy, and the Wealth Distribution," Journal of Economic Theory 105, 120-139.

Greenwood, Jeremy and Boyan Jovanovic (1990), "Financial Development, Growth, and the Distribution of Income," Journal of Political Economy 98, 1076-1107.

Islam, Nazrul (1995), "Growth Empirics: A Panel Data Approach," Quarterly Journal of Economics 110, 1127-1170.

Kane, Thomas J. and Cecilia E. Rouse (1995), "Labor-Market Returns to Two- and FourYear College," American Economic Review 85(3), June, 600-614.

King, Robert G. and Ross Levine (1993), "Finance and Growth: Schumpeter Might be Right," Quarterly Journal of Economics 108, 717-737.

Koopmans, Tjalling C. (1965), "On the Concept of Optimal Economic Growth," in The Econometric Approach to Development Planning (Amsterdam, N. Holland).

Kormendi, Roger and Philip Meguire (1985), "Macroeconomic Determinants of Growth: Cross-Country Evidence," Journal of Monetary Economics 16, 141-163.

Levine, Ross and David Renelt (1992), "A Sensitivity Analysis of Cross-Country Growth Regressions," American Economic Review 82, 942-963.

Lucas, Robert E. (1988), "On the Mechanics of Economic Development," Journal of Monetary Economics 22, 3-42.

Mankiw, N. Gregory, David Romer, and David N. Weil (1992), "A Contribution to the Empirics of Economic Growth, "Quarterly Journal of Economics 107, 407-437.

Marlow, Michael L. (2001), "Bureaucracy and Student Performance in U.S. Public Schools," Applied Economics 33, 1341-1350.

Quah, Danny T. (1997), "Empirics for Growth and Distribution: Stratification, Polarization, and Convergence Clubs," Journal of Economic Growth 2, 27-59.

Ramsey, F. (1928), “A Mathematical Theory of Saving,” Economic Journal 38, 543-559. Rappaport, Jordan (1999), "Local Growth Empirics," CID Working Paper, No. 23, July. Rousseau, Peter L. and Paul Watchel (1998), "Financial Intermediation and Economic Performance: Historical Evidence from Five Industrialized Countries," Journal of Money, Credit and Banking 30, 657-678.

Sala-i-Martin, Xavier X. (1996), "Regional Cohesion: Evidence and Theories of Regional Growth and Convergence," European Economic Review 40, 1325-1352.

Siegfried, John and Andrew Zimbalist (2000), "The Economics of Sports Facilities and Their Communities," Journal of Economic Perspectives 14, 95-114.

Slemrod, Joel (1995), "What Do Cross-Country Studies Teach Us about Government Involvement, Prosperity, and Economic Growth," BPEA 2, 373-431.

Solow, Robert M. (1956), "A Contribution to the Theory of Economic Growth," Quarterly Journal of Economics 70, 65-94.

Surette, Brian J. (1997), "The Effects of Two-Year College on the Labor Market and Schooling Experiences of Young Men," Board of Governors of the Fed. Reserve System, Finance and Economics Discussion Series, No. 1997/44, September. 
Swan, Trevor W. (1956), "Economic Growth and Capital Accumulation," Economic Record 32, 334-361.

Tamura, Robert (1991), "Income Convergence in an Endogenous Growth Model," Journal of Political Economy 99, 522-540.

Walker, Douglas M. and John D. Jackson (1998), "New Goods and Economic Growth: Evidence from Legalized Gambling," Review of Regional Studies 28, 47-69. 
Table 1. Composition of Regional Classifications

$\underline{\text { Region }}$

New England

$\begin{array}{ll}\text { Maine } & 16 \\ \text { New Hampshire } & 10 \\ \text { Vermont } & 14 \\ \text { Massachusetts } & 14 \\ \text { Connecticut } & 8 \\ \text { Rhode Island } & 5 \\ \text { Delaware } & 3 \\ \text { Washington, D.C. } & 1 \\ \text { Maryland } & 24 \\ \text { New Jersey } & 20 \\ \text { New York } & 62 \\ \text { Pennsylvania } & 67\end{array}$

Great Lakes

$\begin{array}{ll}\text { Illinois } & 102 \\ \text { Indiana } & 92 \\ \text { Michigan } & 83 \\ \text { Ohio } & 88 \\ \text { Wisconsin } & 70\end{array}$

Western

$\begin{array}{ll}\text { Alaska } & 9 \\ \text { California } & 58 \\ \text { Hawaii } & 4 \\ \text { Nevada } & 17 \\ \text { Oregon } & 36 \\ \text { Washington } & 39 \\ \text { Arizona } & 9 \\ \text { New Mexico } & 32 \\ \text { Oklahoma } & 77 \\ \text { Texas } & 254\end{array}$

Plains

$\begin{array}{ll}\text { Iowa } & 99 \\ \text { Kansas } & 106 \\ \text { Minnesota } & 87 \\ \text { Missouri } & 115 \\ \text { Nebraska } & 93 \\ \text { North Dakota } & 53 \\ \text { South Dakota } & 66 \\ \text { Colorado } & 63 \\ \text { Idaho } & 44 \\ \text { Montana } & 56 \\ \text { Utah } & 29 \\ \text { Wyoming } & 23\end{array}$

Southeastern

$\begin{array}{ll}\text { North Carolina } & 100 \\ \text { South Carolina } & 45 \\ \text { Georgia } & 159 \\ \text { Florida } & 67 \\ \text { Tennessee } & 95 \\ \text { Alabama } & 67 \\ \text { Mississippi } & 82 \\ \text { Louisiana } & 64 \\ \text { Arkansas } & 74 \\ \text { Kentucky } & 120 \\ \text { Virginia } & 84 \\ \text { West Virginia } & \underline{55} \\ & \underline{3,066^{1}}\end{array}$

\footnotetext{
${ }^{1}$ The actual sample we study includes 3,058 of the 3,066 counties. Eight counties, primarily located in Alaska and Hawaii, are excluded from the
} study due to lack of available data for them. 
Table 2. Variable Definitions and their Source

\begin{tabular}{|c|c|c|c|}
\hline Variable & Definition & Period & Source \\
\hline Income & $\begin{array}{l}\text { Per Capita Personal Income (excluding } \\
\text { transfer payments) }\end{array}$ & 1969-1998 & $\mathrm{BEA}^{2}$ \\
\hline Land area & Land area in $\mathrm{km}^{2}$ & $1970-1990$ & Census $^{3}$ \\
\hline Water area & Water area in $\mathrm{km}^{2}$ & $1970-1990$ & Census \\
\hline Age: $5-13$ years & Percent of $5-13$ year olds in the population & $1970-1990$ & Census \\
\hline Age: $14-17$ years & $\begin{array}{l}\text { Percent of } 14-17 \text { year olds in the } \\
\text { population }\end{array}$ & $1970-1990$ & Census \\
\hline Age: $18-64$ years & $\begin{array}{l}\text { Percent of } 18-64 \text { year olds in the } \\
\text { population }\end{array}$ & $1970-1990$ & Census \\
\hline Age: $65+$ & Percent of $65+$ olds & 1970-1990 & Census \\
\hline Blacks & Percent of Blacks & $1970-1990$ & Census \\
\hline Hispanic & Percent of Hispanics & 1970-1990 & Census \\
\hline Education: 9-11 years & $\begin{array}{l}\text { Percent of population with } 11 \text { years } \\
\text { education or less }\end{array}$ & $1970-1990$ & Census \\
\hline Education: H.S. diploma & $\begin{array}{l}\text { Percent of population with high school } \\
\text { diploma }\end{array}$ & $1970-1990$ & Census \\
\hline Education: Some college & $\begin{array}{l}\text { Percent of population with some college } \\
\text { education }\end{array}$ & $1970-1990$ & Census \\
\hline Education: Bachelor + & $\begin{array}{l}\text { Percent of population with bachelor degree } \\
\text { or above }\end{array}$ & $1970-1990$ & Census \\
\hline Education: Public elementary & $\begin{array}{l}\text { Number of students enrolled in public } \\
\text { elementary schools }\end{array}$ & $1970-1990$ & Census \\
\hline Education: Public nursery & $\begin{array}{l}\text { Number of students enrolled in public } \\
\text { nurseries }\end{array}$ & $1970-1990$ & Census \\
\hline Education: Private elementary & $\begin{array}{l}\text { Number of students enrolled in private } \\
\text { elementary schools }\end{array}$ & $1970-1990$ & Census \\
\hline Education: Private nursery & $\begin{array}{l}\text { Number of students enrolled in private } \\
\text { nurseries }\end{array}$ & $1970-1990$ & Census \\
\hline Housing & Median house value & $1970-1990$ & Census \\
\hline Federal government employment & $\begin{array}{l}\text { Percent of population employed by the } \\
\text { federal government in the county }\end{array}$ & $1969-1998$ & BEA \\
\hline State government employment & $\begin{array}{l}\text { Percent of population employed by the } \\
\text { state government in the county }\end{array}$ & $1969-1998$ & BEA \\
\hline Local government employment & $\begin{array}{l}\text { Percent of population employed by the } \\
\text { local government in the county }\end{array}$ & $1969-1998$ & BEA \\
\hline Self-employment & Percent of population self-employed & $1970-1990$ & Census \\
\hline Agriculture & $\begin{array}{l}\text { Percent of population employed in } \\
\text { agriculture }\end{array}$ & $1970-1990$ & Census \\
\hline Communications & $\begin{array}{l}\text { Percent of population employed in } \\
\text { communications }\end{array}$ & $1970-1990$ & Census \\
\hline Construction & $\begin{array}{l}\text { Percent of population employed in } \\
\text { construction }\end{array}$ & $1970-1990$ & Census \\
\hline Finance, insurance \& real estate & $\begin{array}{l}\text { Percent of population employed in finance, } \\
\text { insurance, and real estate }\end{array}$ & $1970-1990$ & Census \\
\hline Manufacturing: durables & $\begin{array}{l}\text { Percent of population employed in } \\
\text { Manufacturing of durables }\end{array}$ & $1970-1990$ & Census \\
\hline Manufacturing: non-durables & $\begin{array}{l}\text { Percent of population employed in } \\
\text { manufacturing of non-durables }\end{array}$ & $1970-1990$ & Census \\
\hline Mining & Percent of population employed in mining & 1970-1990 & Census \\
\hline Retail & $\begin{array}{l}\text { Percent of population employed in retail } \\
\text { trade }\end{array}$ & $1970-1990$ & Census \\
\hline Business \& repair services & $\begin{array}{l}\text { Percent of population employed in } \\
\text { business and repair services }\end{array}$ & $1970-1990$ & Census \\
\hline Educational services & $\begin{array}{l}\text { Percent of population employed in } \\
\text { education services }\end{array}$ & $1970-1990$ & Census \\
\hline Professional related services & $\begin{array}{l}\text { Percent of population employed in } \\
\text { professional services }\end{array}$ & $1970-1990$ & Census \\
\hline Health services & $\begin{array}{l}\text { Percent of population employed in health } \\
\text { services }\end{array}$ & 1970-1990 & Census \\
\hline Personal services & $\begin{array}{l}\text { Percent of population employed in } \\
\text { personal services }\end{array}$ & 1970-1990 & Census \\
\hline
\end{tabular}

2 All BEA variables are available annually from 1969 to 1998.

3 Note, all Census variables are gathered from the 1970, 1980 \& 1990 Census tapes. Values for 1969 were obtained via the interpolation method as discussed in the data section. 
Table 2. Variable Definitions and their Source (continued)

\begin{tabular}{|l|l|l|l|}
\hline Entertainment \& recreational services & $\begin{array}{l}\text { Percent of population employed in } \\
\text { entertainment and recreational services }\end{array}$ & $1970-1990$ & Census \\
\hline Transportation & $\begin{array}{l}\text { Percent of population employed in } \\
\text { transportation }\end{array}$ & $1970-1990$ & Census \\
\hline Wholesale trade & $\begin{array}{l}\text { Percent of population employed in } \\
\text { wholesale trade }\end{array}$ & $1970-1990$ & Census \\
\hline Poverty & $\begin{array}{l}\text { Percent of the population living at or } \\
\text { below the poverty level }\end{array}$ & $1970-1990$ & Census \\
\hline Metro area, 1970 & $\begin{array}{l}\text { Dummy Variable: } 1 \text { if the county was in a } \\
\text { metro area in } 1970 \text {, and 0 otherwise }\end{array}$ & 1970 & Census \\
\hline Federal government wages & Federal government wages & $1970-1998$ & BEA \\
\hline State government wages & State government wages & $1970-1998$ & BEA \\
\hline Local government wages & Local government wages & $1970-1998$ & BEA \\
\hline Non-government wages & $\begin{array}{l}\text { Growth rate of the wages of private and } \\
\text { farm employees }\end{array}$ & $1970-1998$ & BEA \\
\hline
\end{tabular}


Table 3. Beta Estimates

$\underline{\text { Region }}$

Area

Number of Counties

All counties

United States

United States

United States

Great Lakes

Great Lakes

Great Lakes

New England

New England

New England

Plains

Plains

Plains

Southern

Southern

Southern

Western

Western

Western

Metro counties

Non-metro counties

All counties

Metro counties

Non-metro counties

All counties

Metro counties

Non-metro counties

All counties

Metro counties

Non-metro counties

All counties

Metro counties
867
2,191

435

295

244

90

154

832

1,009

252

757

538

538

242
Unconditional_

$-0.0068(15.88)^{*}$

$-0.0024(3.15)^{*}$

$-0.0101(20.03) *$

$0.0002(0.19)$

$0.0068(2.39) * *$

$-0.0056(3.78)^{*}$

Non-metro counties

$0.0105(7.10)^{*}$

$0.0147(5.91)^{*}$

$0.0085(4.13) *$

$-0.0090(8.01)^{*}$

$0.0016(0.81)$

$-0.0114(9.27)^{*}$

$-0.0025(3.68)^{*}$

$-0.0025(1.82)^{* *}$

$-0.0050(6.12)^{*}$

$-0.0084(8.06) *$

$-0.0024(1.69)^{* * * *}$

$-0.0141(10.29)^{*}$

\begin{tabular}{ll}
\multicolumn{3}{c}{ Conditional } \\
\hline OLS_LSL__ & \\
\cline { 2 - 2 }$-0.0174(22.15)^{*}$ & $-0.0345(24.19)^{*}$ \\
$-0.0132(8.10)^{*}$ & $-0.0354(29.96)^{*}$ \\
$-0.0192(21.12)^{*}$ & $-0.0337(18.42)^{*}$ \\
& \\
$-0.0171(7.51)^{*}$ & $-0.0289(16.93)^{*}$ \\
$-0.0114(1.18)$ & $-0.0328(13.08)^{*}$ \\
$-0.0190(6.67)^{*}$ & $-0.0272(14.14)^{*}$ \\
$0.0030(0.73)$ & $-0.0264(10.86)^{*}$ \\
$0.0026(0.35)$ & $-0.0268(6.51)^{*}$ \\
$-0.0021(0.41)$ & $-0.0281(10.18)^{*}$ \\
$-0.0181(12.25)^{*}$ & $-0.0266(5.84)^{*}$ \\
$-0.0077(2.05)^{* *}$ & $-0.0271(8.91)^{*}$ \\
$-0.0185(11.45)^{*}$ & $-0.0308(6.39)^{*}$ \\
& \\
$-0.0164(11.40)^{*}$ & $-0.0381(34.69)^{*}$ \\
$-0.0115(4.51)^{*}$ & $-0.0344(24.15)^{*}$ \\
$-0.0161(9.97)^{*}$ & $-0.0382(28.45)^{*}$ \\
& \\
$-0.0205(11.34)^{*}$ & $-0.0358(17.84)^{*}$ \\
$-0.0096(3.00)^{*}$ & $-0.0391(20.52)^{*}$ \\
$-0.0225(9.23)^{*}$ & $-0.0356(15.93)^{*}$
\end{tabular}

$t$-statistics are reported in parentheses
* significant at $1 \%$ level
** significant at 5\% level

*** significant at $10 \%$ level 
Table 4. Asymptotic Conditional Convergence Rates: Point Estimates with 95\% Confidence Intervals

\begin{tabular}{|c|c|c|c|c|}
\hline$\underline{\text { Region }}$ & Area & Number of Counties & OLS Estimates and 95\% C.I. & 2SLS Estimates and $95 \%$ C.I. \\
\hline United States & All counties & 3,058 & $0.0237(0.0208,0.0267)$ & $0.0682(0.0544,0.0911)$ \\
\hline United States & Metro counties & 867 & $0.0164(0.0116,0.0217)$ & $0.0749(0.0611,0.0984)$ \\
\hline United States & Non-metro counties & 2,191 & $0.0272(0.0236,0.0312)$ & $0.0642(0.0489,0.0925)$ \\
\hline Great Lakes & All counties & 435 & $0.0229(0.0154,0.0324)$ & $0.0448(0.0357,0.0571)$ \\
\hline Great Lakes & Metro counties & 140 & $0.0135(0.0022,0.0302)$ & $0.0592(0.0417,0.0966)$ \\
\hline Great Lakes & Non-metro counties & 295 & $0.0268(0.0167,0.0409)$ & $0.0400(0.0323,0.0499)$ \\
\hline New England & Metro counties & 90 & $-0.0025(-0.0143,0.0149)$ & $0.0389(0.0223,0.0710)$ \\
\hline New England & Non-metro counties & 154 & $0.0022(-0.0073,0.0148)$ & $0.0422(0.0294,0.0626)$ \\
\hline Plains & All counties & 832 & $0.0249(0.0196,0.0311)$ & $0.0383(0.0206,0.0753)$ \\
\hline Plains & Metro counties & 143 & $0.0086(0.0003,0.0194)$ & $0.0396(0.0265,0.0608)$ \\
\hline Plains & Non-metro counties & 689 & $0.0258(0.0199,0.0329)$ & $0.0511(0.0268,0.1813)$ \\
\hline Southern & All counties & 1,009 & $0.0217(0.0169,0.0272)$ & $0.1033(0.0785,0.1832)$ \\
\hline Southern & Metro counties & 252 & $0.0202(0.0101,0.0344)$ & $0.0678(0.0542,0.0907)$ \\
\hline Southern & Non-metro counties & 757 & $0.0212(0.0159,0.0273)$ & $0.1061(0.0760,0.1594)$ \\
\hline Western & All counties & 538 & $0.0301(0.0228,0.0393)$ & $0.0778(0.0555,0.1726)$ \\
\hline Western & Metro counties & 242 & $0.0111(0.0035,0.0208)$ & $0.1253(0.0738,0.2593)$ \\
\hline Western & Non-metro counties & 296 & $0.0349(0.0242,0.0503)$ & $0.0759(0.0527,0.1521)$ \\
\hline
\end{tabular}


Table 5. Analysis of Growth: The Effect of Selected Education Variables

\begin{tabular}{|c|c|c|c|c|c|c|c|c|}
\hline \multirow[b]{2}{*}{$\underline{\text { Region }}$} & \multirow[b]{2}{*}{$\underline{\text { Area }}$} & \multirow[b]{2}{*}{$\underline{\text { Number of Counties }}$} & \multicolumn{2}{|c|}{ _High School Diploma } & \multicolumn{2}{|c|}{ Some College Education } & \multicolumn{2}{|c|}{ Bachelor Degree or Higher } \\
\hline & & & $\underline{\text { OLS }}$ & 2SLS & $\underline{\mathrm{OLS}}$ & $\underline{2 S L S}$ & $\underline{\text { OLS }}$ & 2SLS \\
\hline United States & All counties & 3,058 & $0.0015(0.54)$ & $0.0097(3.26)^{*}$ & $-0.0119(2.10)^{* *}$ & $-0.0025(0.41)$ & $0.0456(7.85)^{*}$ & $0.0732(12.01)^{*}$ \\
\hline United States & Metro counties & 867 & $-0.0023(0.40)$ & $0.0013(0.20)$ & $-0.0071(0.59)$ & $-0.0044(0.32)$ & $0.0613(5.60)^{*}$ & $0.1138(9.98)^{*}$ \\
\hline United States & Non-metro counties & 2,191 & $0.0025(0.76)$ & $0.0115(3.36)^{*}$ & $-0.0069(1.07)$ & $0.0032(0.47)$ & $0.0364(5.04)^{*}$ & $0.0574(7.62)^{*}$ \\
\hline Great Lakes & All counties & 435 & $-0.0158(2.89)^{*}$ & $-0.0082(1.51)$ & $0.0306(2.01)^{* *}$ & $0.0393(2.51)^{* *}$ & $0.0420(2.91)^{*}$ & $0.0613(4.25)^{*}$ \\
\hline Great Lakes & Metro counties & 140 & $-0.0001(0.10)$ & $0.0056(0.44)$ & $-0.0271(0.80)$ & $-0.0279(0.75)$ & $0.0625(2.08)^{* * *}$ & $0.1066(3.41)^{*}$ \\
\hline Great Lakes & Non-metro counties & 295 & $-0.0177(2.51)^{* *}$ & $-0.0116(1.70)^{* * *}$ & $0.0358(1.90)^{* * *}$ & $0.0451(2.38)^{* *}$ & $0.0468(2.44)^{* *}$ & $0.0546(2.84)^{*}$ \\
\hline New England & All counties & 244 & $-0.0128(1.25)$ & $-0.0199(1.74)^{* * * *}$ & $-0.0113(0.45)$ & $-0.0156(0.55)$ & $0.0570(2.62) *$ & $0.1030(4.42)^{*}$ \\
\hline New England & Metro counties & 90 & $-0.0427(2.60)^{*}$ & $-0.0505(2.68)^{*}$ & $0.0389(0.98)$ & $0.0472(1.04)$ & $0.0997(2.38)^{* *}$ & $0.0998(2.06)^{* *}$ \\
\hline New England & Non-metro counties & 154 & $-0.0107(0.85)$ & $-0.0141(1.01)$ & $0.0012(0.04)$ & $0.0028(0.08)$ & $0.0662(2.41)^{* *}$ & $0.1205(4.29)^{*}$ \\
\hline Plains & All counties & 832 & $0.0099(1.85)^{* * *}$ & $0.0161(3.00)^{*}$ & $-0.0310(3.36)^{*}$ & $-0.0281(3.00)^{*}$ & $0.0099(0.83)$ & $0.0207(1.71)^{* * *}$ \\
\hline Plains & Metro counties & 143 & $0.0312(2.54)^{* *}$ & $0.0343(2.47)^{* *}$ & $-0.0036(0.17)$ & $-0.0088(0.37)$ & $0.0410(1.81)^{* * *}$ & $0.0765(3.15)^{*}$ \\
\hline Plains & Non-metro counties & 689 & $0.0051(0.84)$ & $0.0155(2.49)^{* *}$ & $-0.0278(2.70)^{*}$ & $-0.0224(2.09)^{* *}$ & $-0.0082(0.59)$ & $0.0072(0.50)$ \\
\hline Southern & All counties & 1,009 & $0.0053(1.04)$ & $0.0106(1.85)^{* * * *}$ & $0.0366(2.74)^{*}$ & $0.0377(2.54)^{* *}$ & $0.0449(3.84)^{*}$ & $0.0862(6.82)^{*}$ \\
\hline Southern & Metro counties & 252 & $0.0125(0.87)$ & $0.0111(0.72)$ & $0.0042(0.12)$ & $0.0037(0.10)$ & $0.0508(1.88)^{* * * *}$ & $0.0906(3.25)^{*}$ \\
\hline Southern & Non-metro counties & 757 & $0.0047(0.86)$ & $0.0125(2.05)^{* *}$ & $0.0458(3.17)^{*}$ & $0.0473(2.91)^{*}$ & $0.0496(3.33)^{*}$ & $0.0932(5.69)$ \\
\hline Western & All counties & 538 & $0.0108(1.28)$ & $0.0203(2.26)^{* * *}$ & $0.0118(0.83)$ & $0.0197(1.30)$ & $0.0222(1.60)$ & $0.0405(2.76)^{*}$ \\
\hline Western & Metro counties & 242 & $-0.0068(0.50)$ & $0.0025(0.16)$ & $-0.0286(1.19)$ & $0.0018(0.06)$ & $0.0330(1.43)$ & $0.0839(3.15)^{*}$ \\
\hline Western & Non-metro counties & 296 & $0.0305(2.63)^{*}$ & $0.0393(3.24)^{*}$ & $0.0341(1.79)^{* * *}$ & $0.0426(2.13)^{* *}$ & $0.0022(0.11)$ & $0.0279(1.32)$ \\
\hline
\end{tabular}

$t$-statistics are reported in parentheses

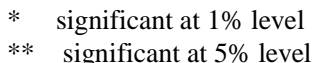

$\begin{array}{lc}* * & \text { significant at } 5 \% \text { level } \\ * * * & \text { significant at } 10 \% \text { level }\end{array}$ 
Table 6. Analysis of Growth: The Effect of Selected Government Variables

Federal Government Employment

$\underline{\text { Area }}$

All counties

Metro counties

Non-metro counties

Number of Counties

All counties

Metro counties

Non-metro counties

All counties

Metro counties

Non-metro counties

All counties

Metro counties

Non-metro counties

All counties

Metro counties

Non-metro counties

All counties

Metro counties

Non-metro counties

\begin{tabular}{|c|c|}
\hline OLS & 2SLS \\
\hline$-0.0145(2.99)^{*}$ & $-0.0222(4.26)^{*}$ \\
\hline$-0.0108(1.12)$ & $-0.0318(2.99)^{*}$ \\
\hline$-0.0135(2.34)^{* *}$ & $-0.0171(2.79)^{*}$ \\
\hline$-0.0001(0.01)$ & $-0.0043(0.30)$ \\
\hline $0.0192(0.63)$ & $-0.0040(0.12)$ \\
\hline $0.0063(0.34)$ & $0.0078(0.42)$ \\
\hline$-0.0155(0.86)$ & $-0.0291(1.44)$ \\
\hline $0.0554(1.71)^{* * *}$ & $0.0428(1.14)$ \\
\hline$-0.0156(0.69)$ & $-0.0297(1.20)$ \\
\hline$-0.0162(1.56)$ & $-0.0221(2.10)^{* *}$ \\
\hline$-0.0213(0.85)$ & $-0.0145(0.52)$ \\
\hline$-0.0134(1.15)$ & $-0.0214(1.78)^{* * *}$ \\
\hline$-0.0153(1.88)^{* * *}$ & $-0.0242(2.68)^{*}$ \\
\hline$-0.0188(0.93)$ & $-0.0321(1.94) * * *$ \\
\hline$-0.0153(1.66)^{* * *}$ & $-0.0172(1.65)^{* * *}$ \\
\hline$-0.0147(1.37)$ & $-0.0175(1.52)$ \\
\hline$-0.0021(0.11)$ & $-0.0177(0.80)$ \\
\hline$-0.0083(0.58)$ & $-0.0087(0.58)$ \\
\hline
\end{tabular}

S

\begin{tabular}{|c|c|}
\hline OLS & 2SLS \\
\hline$-0.0029(0.76)$ & $-0.0163(4.07) *$ \\
\hline$-0.0058(0.85)$ & $-0.0263(3.51)^{*}$ \\
\hline $0.0028(0.61)$ & $-0.0071(1.65)^{* * *}$ \\
\hline$-0.0059(0.68)$ & $-0.0148(1.68) * * *$ \\
\hline$-0.0102(0.55)$ & $-0.0274(1.67)^{* * *}$ \\
\hline$-0.0137(1.30)$ & $-0.0197(1.88)^{* * *}$ \\
\hline$-0.0006(0.05)$ & $-0.0121(0.93)$ \\
\hline$-0.0115(0.41)$ & $-0.0202(0.62)$ \\
\hline $0.0088(0.66)$ & $0.0019(0.13)$ \\
\hline $0.0131(1.69)^{* * *}$ & $0.0065(0.84)$ \\
\hline$-0.0166(1.22)$ & $-0.0355(2.40)^{* *}$ \\
\hline $0.0247(2.74) *$ & $0.0170(1.82)^{* * *}$ \\
\hline $0.0034(0.52)$ & $-0.0016(1.58)$ \\
\hline $0.0073(0.45)$ & $-0.0119(0.70)$ \\
\hline $0.0009(0.12)$ & $-0.0121(1.44)$ \\
\hline$-0.0009(0.10)$ & $-0.0152(1.49)$ \\
\hline$-0.0054(0.41)$ & $-0.0228(1.65) * * *$ \\
\hline $0.0104(0.70)$ & $-0.0041(0.26)$ \\
\hline
\end{tabular}

Local Government Employment

\begin{tabular}{ll}
\multicolumn{1}{c}{ OLS } & \multicolumn{1}{c}{$\underline{2 S L S}$} \\
$-0.0219(4.52)^{*}$ & $-0.0204(3.91)^{*}$ \\
$-0.0161(1.52)$ & $-0.0230(1.95)^{* * *}$ \\
$-0.0165(2.94)^{*}$ & $-0.0128(2.15)^{* *}$ \\
& \\
$-0.0256(2.21)^{* *}$ & $-0.0278(2.34)^{* *}$ \\
$-0.0714(1.99)^{* *}$ & $-0.0493(1.26)$ \\
$-0.0300(2.24)^{* *}$ & $-0.0303(2.23)^{* *}$ \\
& \\
$-0.0191(0.88)$ & $-0.0412(1.70)^{* * *}$ \\
$-0.0350(0.63)$ & $-0.0877(1.41)$ \\
$-0.0113(0.41)$ & $-0.0352(1.13)$ \\
& \\
$-0.0047(0.55)$ & $-0.0001(0.02)$ \\
$-0.0147(0.78)$ & $-0.095(0.45)$ \\
$0.0062(0.62)$ & $0.0146(1.41)$ \\
& \\
$-0.0011(0.11)$ & $-0.0072(0.65)$ \\
$-0.0141(0.45)$ & $-0.0113(0.34)$ \\
$0.0043(0.42)$ & $-0.0004(0.04)$ \\
& \\
$-0.0239(2.04)^{* *}$ & $-0.0291(2.32)^{* *}$ \\
$-0.0155(0.83)$ & $-0.0438(1.99)^{* *}$ \\
$-0.0214(1.29)$ & $-0.0229(1.31)$
\end{tabular}

$t$-statistics are reported in parentheses

* $\quad$ significant at $1 \%$ level

** $\quad$ significant at $5 \%$ level

*** significant at $10 \%$ level 
(a) All Counties (3,066 counties)

\begin{tabular}{|c|c|c|c|}
\hline Level & Non-Government ${ }^{4}>$ Government & Government $>$ Non-Government & $\begin{array}{c}\text { \% counties where growth of } \\
\text { government wages are greater } \\
\text { than growth of non-government } \\
\text { wages }\end{array}$ \\
\hline Federal & 1,706 & 1,360 & $44.36 \%$ \\
\hline State & 1,675 & 1,391 & $45.37 \%$ \\
\hline Local & 909 & 2,157 & $70.35 \%$ \\
\hline
\end{tabular}

(b) Higgins-Levy-Young Metro Counties (870 counties)

\begin{tabular}{|c|c|c|c|}
\hline Level & Non-Government>Government & Government>Non-Government & $\begin{array}{c}\text { \% counties where growth of } \\
\text { government wages are greater } \\
\text { than growth of non-government } \\
\text { wages }\end{array}$ \\
\hline Federal & 573 & 297 & $34.14 \%$ \\
\hline State & 532 & 338 & $38.85 \%$ \\
\hline Local & 364 & 506 & $58.16 \%$ \\
\hline
\end{tabular}

(c) Higgins-Levy-Young Non-Metro Counties (2,196 counties)

\begin{tabular}{|c|c|c|c|}
\hline Level & Non-Government>Government & Government>Non-Government & $\begin{array}{c}\text { \% counties where growth of } \\
\text { government wages are greater } \\
\text { than growth of non-government } \\
\text { wages }\end{array}$ \\
\hline Federal & 1133 & 1063 & $48.41 \%$ \\
\hline State & 1143 & 1053 & $47.95 \%$ \\
\hline Local & 545 & 1651 & $75.18 \%$ \\
\hline
\end{tabular}

\footnotetext{
${ }^{4}$ Non-government wages are the sum of private and farm wages.
} 
Table 8: Analysis of Growth: The Effect of Selected Industry Composition Variables

Finance, Insurance, Real Estate

\section{$\underline{\text { Region }}$}

United States

United States

United States

\section{Great Lakes}

Great Lakes

Great Lakes

New England

New England

New England

Plains

Plains

Plains

Southern

Southern

Southern

Western

Western

Western

\section{Westen}

$t$-statistics are reported in parentheses

$\underline{\text { Area }}$

All counties

Metro counties

Non-metro counties

All counties

Metro counties

Non-metro counties

All counties

Metro counties

Non-metro counties

All counties

Metro counties

Non-metro counties

All counties

Metro counties

Non-metro counties

Number of Counties

\begin{tabular}{c} 
OLS \\
\hline \\
$0.0678(5.77)^{*}$ \\
$0.0624(2.93)^{*}$ \\
$0.0691(4.77)^{*}$ \\
\\
$0.0268(1.01)$ \\
$0.0890(1.50)$ \\
$0.0295(0.94)$ \\
\\
$0.0300(1.00)$ \\
$-0.0286(0.56)$ \\
$-0.0475(0.97)$ \\
\\
$0.1084(4.68)^{*}$ \\
$-0.0001(0.01)$ \\
$0.1322(4.92)^{*}$ \\
\\
$0.0263(1.18)$ \\
$0.0357(0.66)$ \\
$-0.0105(0.43)$ \\
\\
$0.1037(3.37)^{*}$ \\
$0.1742(3.70)^{*}$ \\
$0.0567(1.28)$
\end{tabular}

2SLS

3,058

867
2,191

435

140
295

244

90
154

154

832

143

689

1,009

252
757

538

242
296
Educational Services

\begin{tabular}{|c|c|c|c|c|}
\hline 2SLS & OLS & 2SLS & OLS & 2SLS \\
\hline $0.0777(6.16)^{*}$ & $-0.0138(1.72)^{* * *}$ & $-0.0334(3.90) *$ & $0.0428(2.79) *$ & $0.0477(2.89) *$ \\
\hline $0.0633(2.67)^{*}$ & $-0.0193(1.65)^{* * *}$ & $-0.0513(4.00)^{*}$ & $0.0744(2.44)^{* *}$ & $0.0609(1.79)^{* * *}$ \\
\hline $0.0778(5.08)^{*}$ & $0.0034(0.29)$ & $-0.0105(0.84)$ & $0.0326(1.84)^{* * * *}$ & $0.0399(2.13)^{* *}$ \\
\hline $0.0272(1.99) * *$ & $-0.0894(2.84)^{*}$ & $-0.1059(3.27)^{*}$ & $0.0902(1.16)$ & $0.1056(1.32)$ \\
\hline $0.1034(1.59)$ & $-0.1125(1.47)$ & $-0.1466(1.75)^{* * *}$ & $0.5941(3.49)^{*}$ & $0.5551(2.98) *$ \\
\hline $0.0331(1.04)$ & $-0.0705(1.92)^{* * * *}$ & $-0.0776(2.08)^{* *}$ & $0.0023(0.03)$ & $0.0224(0.24)$ \\
\hline $0.0243(1.72)^{* * * *}$ & $-0.0497(1.06)$ & $-0.0834(1.80)^{* * * *}$ & $0.1946(1.87)^{* * *}$ & $0.2068(1.78)^{* * *}$ \\
\hline $0.0059(0.10)$ & $0.0195(0.14)$ & $-0.1429(0.95)$ & $0.0918(0.45)$ & $0.2339(1.86)^{* * *}$ \\
\hline$-0.0488(0.90)$ & $-0.0923(1.76)^{* * *}$ & $-0.1084(1.86)^{* * *}$ & $0.0062(0.05)$ & $-0.0688(0.48)$ \\
\hline $0.1102(4.67)^{*}$ & $0.0051(0.29)$ & $-0.0003(0.02)$ & $0.1636(4.31)^{*}$ & $0.1611(4.16)^{*}$ \\
\hline $0.0213(0.43)$ & $-0.0064(0.13)$ & $-0.0915(1.75)^{* * *}$ & $0.1402(1.78) * * *$ & $0.1940(2.21)^{* *}$ \\
\hline $0.1348(4.81)^{*}$ & $0.0076(0.39)$ & $0.0022(0.11)$ & $0.1830(4.16)^{*}$ & $0.1756(3.83)^{*}$ \\
\hline $0.0481(1.94)^{* * * *}$ & $0.0047(0.22)$ & $-0.0136(0.56)$ & $0.1038(2.53)^{* *}$ & $0.1148(2.52)^{* *}$ \\
\hline $0.0608(1.06)$ & $-0.0986(1.74) * * *$ & $-0.0601(1.00)$ & 0.1717 (1.57) & $0.1125(1.98)^{* *}$ \\
\hline $0.0032(0.12)$ & $0.0494(2.10)^{* *}$ & $0.0103(0.39)$ & $0.0759(1.74)^{* * *}$ & $0.1058(2.16)^{* *}$ \\
\hline $0.1272(3.88)^{*}$ & $-0.0267(1.90)^{* * *}$ & $-0.0405(3.03)^{*}$ & $-0.0072(0.30)$ & $-0.0052(0.20)$ \\
\hline $0.1872(3.33) *$ & $0.0124(0.69)$ & $-0.0493(2.48) * *$ & $0.0295(0.68)$ & $0.0141(0.27)$ \\
\hline $0.0916(1.98)^{* *}$ & $0.0042(0.13)$ & $-0.0185(0.53)$ & $0.0111(0.36)$ & $0.0101(0.31)$ \\
\hline
\end{tabular}

Entertainment \& Recreational Services

\begin{tabular}{|c|c|c|c|c|}
\hline 2SLS & OLS & $2 \mathrm{SLS}$ & OLS & $2 \mathrm{SLS}$ \\
\hline $0.0777(6.16)^{*}$ & $-0.0138(1.72)^{* * * *}$ & $-0.0334(3.90)^{*}$ & $0.0428(2.79)^{*}$ & $0.0477(2.89)^{*}$ \\
\hline $0.0633(2.67)^{*}$ & $-0.0193(1.65)^{* * *}$ & $-0.0513(4.00)^{*}$ & $0.0744(2.44) * *$ & $0.0609(1.79) * * *$ \\
\hline $0.0778(5.08)^{*}$ & $0.0034(0.29)$ & $-0.0105(0.84)$ & $0.0326(1.84)^{* * * *}$ & $0.0399(2.13)^{* *}$ \\
\hline $0.0272(1.99)^{* *}$ & $-0.0894(2.84)^{*}$ & $-0.1059(3.27)^{*}$ & $0.0902(1.16)$ & $0.1056(1.32)$ \\
\hline 0.1034 (1.59) & $-0.1125(1.47)$ & $-0.1466(1.75) * * *$ & $0.5941(3.49) *$ & $0.5551(2.98) *$ \\
\hline $0.0331(1.04)$ & $-0.0705(1.92)^{* * *}$ & $-0.0776(2.08)^{* *}$ & $0.0023(0.03)$ & $0.0224(0.24)$ \\
\hline $0.0243(1.72)^{* * * *}$ & $-0.0497(1.06)$ & $-0.0834(1.80)^{* * * *}$ & $0.1946(1.87)^{* * * *}$ & $0.2068(1.78)^{* * *}$ \\
\hline $0.0059(0.10)$ & $0.0195(0.14)$ & $-0.1429(0.95)$ & $0.0918(0.45)$ & $0.2339(1.86)^{* * *}$ \\
\hline$-0.0488(0.90)$ & $-0.0923(1.76)^{* * *}$ & $-0.1084(1.86)^{* * *}$ & $0.0062(0.05)$ & $-0.0688(0.48)$ \\
\hline $0.1102(4.67)^{*}$ & $0.0051(0.29)$ & $-0.0003(0.02)$ & $0.1636(4.31)^{*}$ & $0.1611(4.16)^{*}$ \\
\hline $0.0213(0.43)$ & $-0.0064(0.13)$ & $-0.0915(1.75)^{* * *}$ & $0.1402(1.78)^{* * * *}$ & $0.1940(2.21)^{* *}$ \\
\hline $0.1348(4.81)^{*}$ & $0.0076(0.39)$ & $0.0022(0.11)$ & $0.1830(4.16)^{*}$ & $0.1756(3.83)^{*}$ \\
\hline $0.0481(1.94)^{* * * *}$ & $0.0047(0.22)$ & $-0.0136(0.56)$ & $0.1038(2.53)^{* *}$ & $0.1148(2.52)^{* * *}$ \\
\hline $0.0608(1.06)$ & $-0.0986(1.74)^{* * *}$ & $-0.0601(1.00)$ & $0.1717(1.57)$ & $0.1125(1.98)^{* *}$ \\
\hline $0.0032(0.12)$ & $0.0494(2.10)^{* *}$ & $0.0103(0.39)$ & $0.0759(1.74)^{* * *}$ & $0.1058(2.16)^{* *}$ \\
\hline $0.1272(3.88)^{*}$ & $-0.0267(1.90)^{* * *}$ & $-0.0405(3.03)^{*}$ & $-0.0072(0.30)$ & $-0.0052(0.20)$ \\
\hline $0.1872(3.33)^{*}$ & $0.0124(0.69)$ & $-0.0493(2.48)^{* *}$ & $0.0295(0.68)$ & $0.0141(0.27)$ \\
\hline $0.0916(1.98)^{* *}$ & $0.0042(0.13)$ & $-0.0185(0.53)$ & $0.0111(0.36)$ & $0.0101(0.31)$ \\
\hline
\end{tabular}

* significant at $1 \%$ level

** significant at $5 \%$ level

*** significant at $10 \%$ level 
Figure 1: Metro \& Non-Metro Counties - Continental U.S.

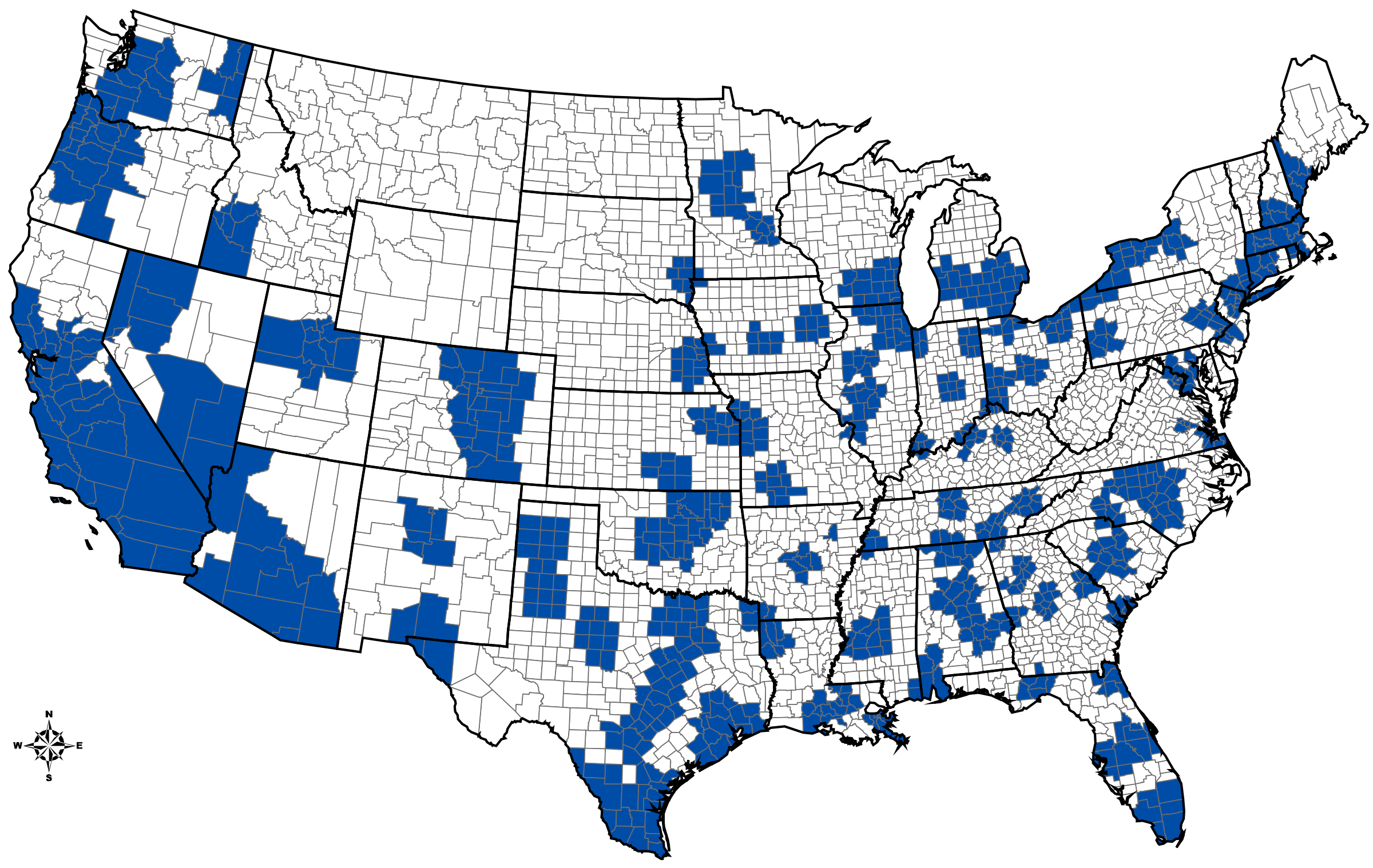

(1) Alaska has 3 metro counties including and surrounding the city of Anchorage

(2) Hawaii has 1 metro county that contains Honolulu

(3) Metro counties are shaded blue 
Figure 2: Regional Classifications

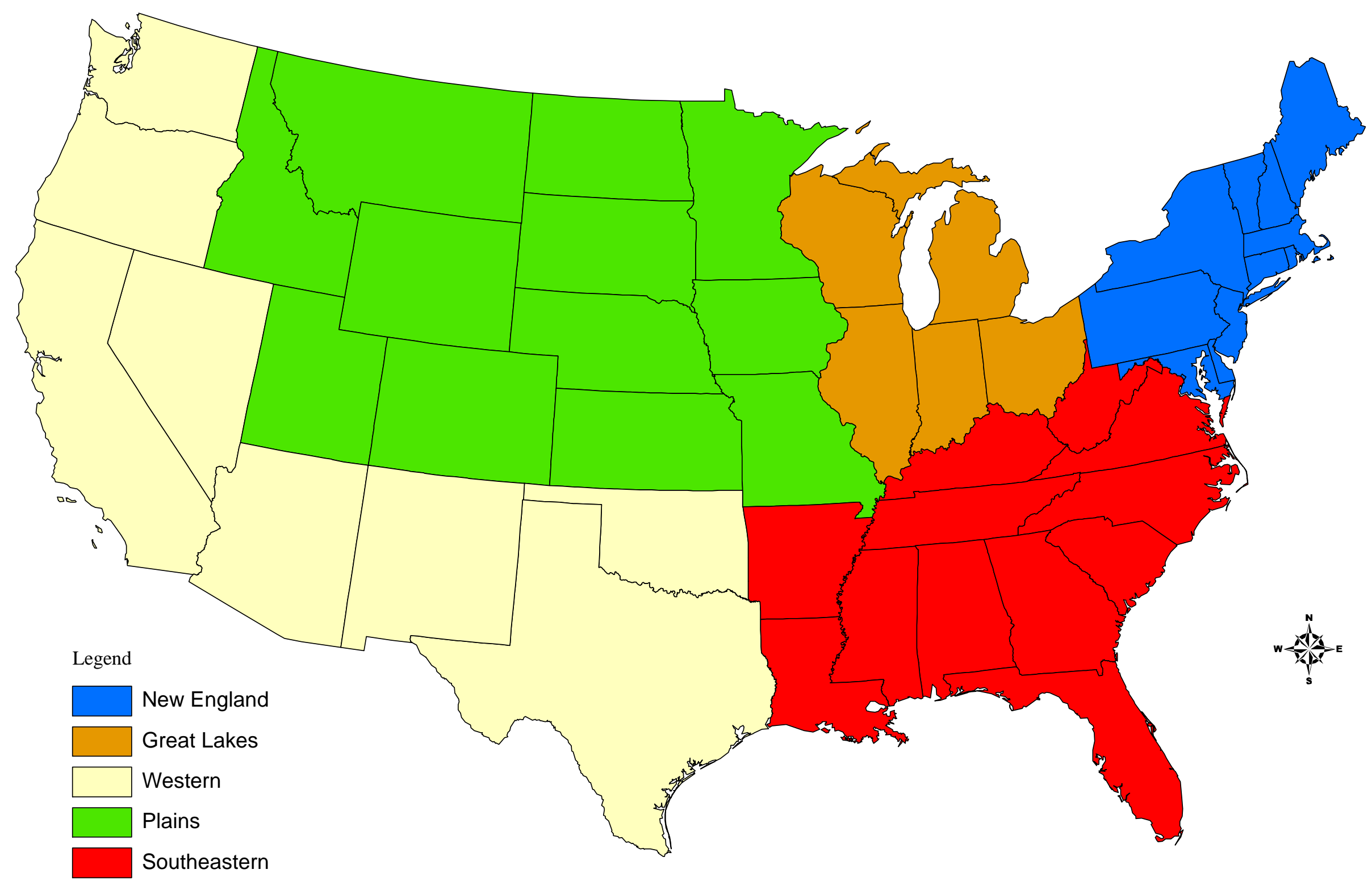

Alaska and Hawaii are included in the Western region 
Figure 3: Unconditional Convergence - Entire United States

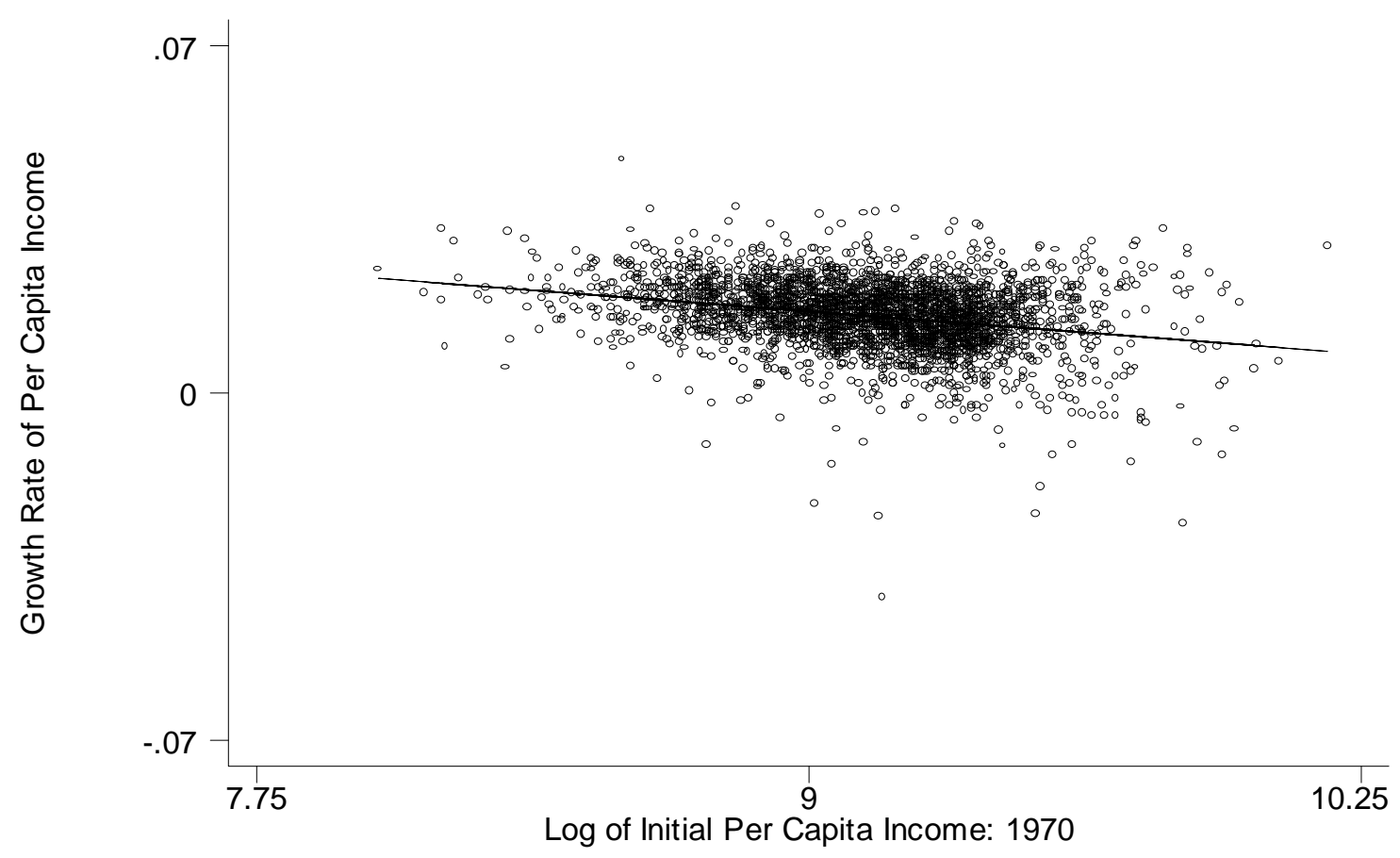




\section{Referee's Appendix}

\section{Inconsistency of OLS Estimates}

The method of ordinary least squares (OLS) could be used to infer the values of $\beta$ and $\gamma$ in equation (3). However, Evans (1997b) states that the OLS estimates obtained from (3) are unlikely to be consistent. ${ }^{1}$ In order to demonstrate this inconsistency, Evans first specifies a general autoregressive moving average (ARMA) data-generating process for $y_{n t}$ :

$$
y_{n t}-a_{t}=\delta_{n}+\lambda_{n}\left(y_{n, t-1}-a_{t-1}\right)+\sum_{i=1}^{q} \theta_{n i} \varepsilon_{n, t-i}
$$

with

$$
\delta_{n}=\kappa+\xi_{n}^{\prime} x_{n}+\omega_{n}
$$

where $\varepsilon_{n t}$ is a zero-mean, covariance stationary error process independently distributed over time and across economies. The error term, $\varepsilon_{n t}$, is uncorrelated with $x_{n}, \lambda_{n}$ is an autoregressive parameter which lies on $(0,1]$, and $\theta_{n 0} \ldots \theta_{n q}$ satisfy the restriction $\theta_{n 0}=1$. As such, $y_{n t}-a_{t}$ will also have an autoregressive representation and will be covariance stationary if $\lambda_{n}<1$ or difference stationary if $\lambda_{n}=1$. The common time-specific effect experienced by every economy is represented by the term $a_{t}$. Evans assumes that $\Delta a_{t}$ is covariance stationary and independent of $\varepsilon_{n t}$.

The common trend $a_{t}$ for all the $y$ variables will be the sole catalyst of economic growth in all economies if $\lambda_{n}<1$. In this case, growth is exogenous and economies would follow a balanced-growth path. If $\lambda_{n}=1$, on the other hand, then economy $n$ will grow endogenously since $y_{n t}$ diverges from $a_{t}$ and the $y$ variables of all remaining economies. The parameter $\delta_{n}$ controls for the relative height of economy $n$ 's balanced growth path if all the $\lambda \mathrm{s}$ are less than one. If $\lambda_{n}=1$, then $\delta_{n}$ controls for economy $n$ 's relative growth rate. The error term $\omega_{n}$ measures the portion of $\delta_{n}$ that is not explained by $x_{n}$. This error term is assumed to be

\footnotetext{
1 This appendix borrows heavily from Evans (1997b), which can be consulted for further details. It is not intended for publication.
} 
uncorrelated with $x_{n}$. The inequality $\lambda_{n}<1$ will hold for an economy described by the neoclassical growth model.

Solving equation (1A) backward from year $T$ to year 0 , substituting from equation (2A), and rearranging produces

$$
\begin{aligned}
& g_{n}=\alpha_{n}+\beta_{n} y_{n 0}+\gamma_{n}^{\prime} x_{n}-\frac{\beta_{n} \omega_{n}}{1-\gamma_{n}}+\frac{1}{T} \sum_{i=0}^{T-1} \lambda_{n}^{i}\left(\sum_{j=0}^{\min [i, q]} \lambda_{n}^{-j} \theta_{n j}\right) \varepsilon_{n, T-i} \\
& +\left(\frac{\lambda_{n}^{T}}{T} \sum_{i=0}^{q-1} \lambda_{n}^{i}\left(\sum_{j=i+1}^{q} \lambda_{n}^{-j} \theta_{n j}\right) \varepsilon_{n,-i}\right.
\end{aligned}
$$

where $\beta_{n}=\frac{\lambda_{n}^{T}-1}{T}, \gamma_{n}=\frac{-\beta_{n} \xi_{n}}{1-\lambda_{n}}$, and $\alpha_{n}=\frac{a_{T}-a_{0}}{T-\beta_{n}\left(\frac{a_{0}+\kappa}{1-\lambda_{n}}\right)}$. If $\beta_{n}<0$, then economy $n$ grows exogenously $\left(\lambda_{n}<1\right)$. On the other hand, if $\beta_{n}=0$, then economy $n$ grows endogenously $\left(\lambda_{n}=1\right)$.

Now consider a special case in which every intercept $\delta_{n}$ is completely explained by the county characteristics included in $x_{n}\left(\omega_{n}=0, \forall n\right)$ and every series $y_{n t}-a_{t}$ is a first-order autoregression $(q=0)$. Under these restrictions equation $(3 \mathrm{~A})$ reduces to:

$$
g_{n}=\alpha_{n}+\beta_{n} y_{n 0}+\gamma_{n}^{\prime} x_{n}+\frac{1}{T} \sum_{i=0}^{T-1} \lambda_{n}^{i} \varepsilon_{n, T-i}
$$

The estimator for $\hat{\beta}$ can then be obtained in two steps. First, regress $y_{n 0}$ on an intercept and $x_{n}$ to obtain the residual $r_{n}$ and then regress $g_{n}$ on $r_{n}$. (This is simply the OLS estimator of $\beta$.) Each term in $\frac{1}{T} \sum_{i=0}^{T-1} \lambda_{n}^{i} \varepsilon_{n, T-i}$ is uncorrelated with the intercept, $y_{n}, x_{n}$ and the residual $r_{n}$. As a result, one has

$$
p \lim _{N \rightarrow \infty} \hat{\beta}=\frac{p \lim _{N \rightarrow \infty} \frac{1}{N} \sum_{n=1}^{N} \alpha_{n} r_{n}+p \lim _{N \rightarrow \infty} \frac{1}{N} \sum_{n=1}^{N} \beta_{n} r_{n} y_{n}+p \lim _{N \rightarrow \infty} \frac{1}{N} \sum_{n=1}^{N} \gamma_{n}^{\prime} r_{n} x_{n}}{p \lim \frac{1}{N} \sum_{n=1}^{N} r_{n}^{2}}
$$


Making further assumptions that $\alpha_{n}$ is uncorrelated with $r_{n}, \beta_{n}$ is uncorrelated with $r_{n} y_{n}$, and $\gamma_{n}$ is uncorrelated with $r_{n} x_{n}$, equation (5A) leads to

$$
p \lim _{N \rightarrow \infty} \hat{\beta}=\frac{p \lim _{N \rightarrow \infty} \frac{1}{N} \sum_{n=1}^{N} \beta_{n} r_{n}^{2}}{p \lim \frac{1}{N} \sum_{n \rightarrow \infty}^{N} r_{n}^{2}}
$$

The probability limit of the OLS estimator is then a weighted average of the economy specific $\beta_{n} \mathrm{~s}$. It is a consistent estimator of that weighted average. ${ }^{2}$

But what if the assumption that every intercept $\delta_{n}$ is completely explained by $x_{n}$ and also the assumption that every series $y_{n t}-a_{t}$ is a first-order auto-regression, are relaxed? Relaxing these assumptions, and imposing the additional restriction that the $\lambda s$ and $\xi_{s}$ and, as a result, the $\beta_{S}$ and $\gamma s$ are identical across all economies (for the simplicity of the exposition), (3A) can be re-written as

$$
\begin{aligned}
& g_{n}=\alpha+\beta y_{n 0}+\gamma^{\prime} x_{n}-\frac{\beta \omega_{n}}{1-\gamma}+\frac{1}{T} \sum_{i=0}^{T-1} \lambda^{i}\left(\sum_{j=0}^{\min [i, q]} \lambda^{-j} \theta_{n j}\right) \varepsilon_{n, T-i} \\
& +\left(\frac{\lambda^{T}}{T}\right)_{i=0}^{q-1} \lambda^{i}\left(\sum_{j=i+1}^{q} \lambda^{-j} \theta_{n j}\right) \varepsilon_{n,-i}
\end{aligned}
$$

where $\beta=\frac{\lambda^{T}-1}{T}, \gamma=\frac{-\beta \xi}{1-\lambda}$, and $\alpha=\frac{a_{T}-a_{0}}{T-\beta\left(\frac{a_{0}+\kappa}{1-\lambda}\right)}$. Applying the same steps to equation (6A) yields

$$
p \lim _{N \rightarrow \infty} \hat{\beta}=\beta+\frac{(\Phi+\Psi)}{p \lim _{N \rightarrow \infty} \frac{1}{N} \sum_{n=1}^{N} r_{n}^{2}}
$$

\footnotetext{
${ }^{2}$ Strictly speaking, even for this restrictive case, an OLS estimate less than unity does not mean that all the economies in the sample conform to the neoclassical growth model. Rather, it would mean that enough economies conform, so that the weighted average is less than unity. It would mean, therefore, that exogenous growth is the predominant case across the sample.
} 
where $\Phi=\frac{\lambda^{T}}{T} p \lim _{N \rightarrow \infty} \frac{I}{N} \sum_{n=1}^{N}\left[\sum_{i=0}^{q-1} \lambda^{i}\left(\sum \lambda^{-j} \theta_{n, j+i+1}\right) r_{n} \varepsilon_{n,-i}\right]$ and $\Psi=-\frac{\beta}{1-\lambda} p \lim _{N \rightarrow \infty} \frac{1}{N} \sum r_{n} \omega_{n}$.

As a result, equation (8A) implies that $p \lim \hat{\beta}$ differs from $\beta$ if either $q>0\left(y_{n t}-a_{t}\right.$ is not a first-order AR process) or the cross-sectional variance of $\omega_{n}$ is positive (not all cross-sectional heterogeneity is accounted for). In other words, the OLS estimator is inconsistent unless (a) the $\log$ of income per capita has an identical first-order AR representation across economies, and (b) all cross-section heterogeneity is controlled for.

Evans shows that the resulting bias from $q>0$ is likely to be negligible in practice but the bias resulting from a positive cross-sectional variance for $\omega_{n}$ can be substantial. This is essentially an omitted variable bias. Evans demonstrates that

$$
\underset{N \rightarrow \infty}{p} \hat{\beta}=\left\lfloor\frac{\operatorname{var}(y \mid x, \omega)}{\operatorname{var}(y \mid x)}\right\rfloor \beta
$$

and

$$
p \lim _{N \rightarrow \infty} \hat{\gamma}=\left\lfloor\frac{\operatorname{var}(y \mid x, \omega)}{\operatorname{var}(y \mid x)}\right\rfloor \gamma
$$

The bracketed portions in equations (9A) and (10A) are the ratio of the cross-sectional variance of $y_{n 0}$ conditional on both $x_{n}$ and $\omega_{n}$ to the cross-sectional variance of $y_{n 0}$ on $x_{n}$. As such, $\hat{\beta}$ and $\hat{\gamma}$ will be biased towards zero unless the $x s$ are able to control for a large portion of the cross-economy variation in the $y s$.

The intuition here is that if a large portion of the growth of per capita income is explained by variables left out of the OLS regression, then the estimate of the convergence effect will be biased. In general, omitted variable bias can be either positive or negative. However, in this case, theoretically, the bias is negative. Evans (1997b, Tables on p. 11 and p. 15) estimates $\beta$ for Mankiw, et al.'s (1992) international data using both the OLS, which yields inconsistent estimates, and the 2SLS approach (as outlined in section 2), which yields consistent estimates of both $\beta$ and $\gamma$. He finds that the 2SLS estimate implies a conditional convergence rate between 4 to 5 times as large as the OLS estimate. The bias produced by the OLS in this case, therefore, is substantial. 


\section{Growth Equation Regression Estimates: Complete Tables}

In Table A1 we report the growth equation estimation results for the entire U.S. In Tables A2-A6 we report the regional growth equation estimation results for the Great Lakes Region, New England Region, Plains Region, Southern Region, and the Western Region, respectively. The information presented in Tables A1-A8 is organized as follows. In the first column of each table, we report the estimation results for all counties together. In the second and third columns we report the estimation results for the metro and non-metro counties, respectively. In each column, we first report the OLS estimation results and then the 2 SLS estimation results. 
Table A1. Growth Equation Estimates: Entire United States

\begin{tabular}{|c|c|c|c|c|c|c|}
\hline \multirow[b]{2}{*}{$\underline{\text { RHS Variables }}^{3}$} & \multicolumn{2}{|c|}{ All } & \multicolumn{2}{|c|}{ Metro } & \multicolumn{2}{|c|}{ Non-Metro } \\
\hline & $\underline{\text { OLS }}$ & $\underline{2 S L S}$ & $\underline{\text { OLS }}$ & $\underline{2 S L S}$ & $\underline{\text { OLS }}$ & 2SLS \\
\hline Constant & $\begin{array}{c}0.1666 \\
(10.47)^{*}\end{array}$ & $\begin{array}{c}0.3299 \\
(21.91)^{*}\end{array}$ & $\begin{array}{l}0.0744 \\
(2.14)^{* *}\end{array}$ & $\begin{array}{l}0.3173 \\
(9.53)^{*}\end{array}$ & $\begin{array}{c}0.1942 \\
(10.58)^{*}\end{array}$ & $\begin{array}{c}0.3287 \\
(19.04)^{*}\end{array}$ \\
\hline $\begin{array}{l}\text { Log } 1970 \text { per capita } \\
\text { income }^{4}\end{array}$ & $\begin{array}{l}-0.0174 \\
(22.15)^{*}\end{array}$ & $\begin{array}{l}-0.0345 \\
(24.19)^{*}\end{array}$ & $\begin{array}{l}-0.0132 \\
(8.10)^{*}\end{array}$ & $\begin{array}{l}-0.0354 \\
(29.96)^{*}\end{array}$ & $\begin{array}{l}-0.0192 \\
(21.12)^{*}\end{array}$ & $\begin{array}{l}-0.0337 \\
(18.42)^{*}\end{array}$ \\
\hline Land area & $\begin{array}{l}-0.0000 \\
(3.33)^{*}\end{array}$ & $\begin{array}{l}-0.0000 \\
(3.73)^{*}\end{array}$ & $\begin{array}{l}-0.0000 \\
(2.24)^{* *}\end{array}$ & $\begin{array}{l}-0.0000 \\
(1.97)^{*}\end{array}$ & $\begin{array}{l}-0.0000 \\
(2.22)^{* *}\end{array}$ & $\begin{array}{l}-0.0000 \\
(2.72)^{*}\end{array}$ \\
\hline Water area & $\begin{array}{l}0.0000 \\
(3.83)^{*}\end{array}$ & $\begin{array}{l}0.0000 \\
(2.85)^{*}\end{array}$ & $\begin{array}{l}0.0000 \\
(2.20)^{* *}\end{array}$ & $\begin{array}{l}0.0000 \\
(2.06)^{* *}\end{array}$ & $\begin{array}{l}0.0000 \\
(2.69)^{*}\end{array}$ & $\begin{array}{l}0.0000 \\
(1.95)^{* * *}\end{array}$ \\
\hline Age: $5-13$ years & $\begin{array}{c}0.0392 \\
(2.16)^{* *}\end{array}$ & $\begin{array}{l}0.0418 \\
(2.14)^{* *}\end{array}$ & $\begin{array}{l}0.0684 \\
(1.67)^{* * *}\end{array}$ & $\begin{array}{l}0.0585 \\
(1.29)\end{array}$ & $\begin{array}{l}0.0237 \\
(1.15)\end{array}$ & $\begin{array}{l}0.0263 \\
(1.20)\end{array}$ \\
\hline Age: $14-17$ years & $\begin{array}{l}0.0241 \\
(1.48)\end{array}$ & $\begin{array}{l}0.0214 \\
(1.22)\end{array}$ & $\begin{array}{l}0.0374 \\
(1.15)\end{array}$ & $\begin{array}{l}0.0226 \\
(0.63)\end{array}$ & $\begin{array}{l}0.0196 \\
(1.03)\end{array}$ & $\begin{array}{l}0.0198 \\
(0.98)\end{array}$ \\
\hline Age: $18-64$ years & $\begin{array}{l}0.0132 \\
(0.99)\end{array}$ & $\begin{array}{l}0.0072 \\
(0.50)\end{array}$ & $\begin{array}{l}0.0449 \\
(1.53)\end{array}$ & $\begin{array}{l}0.0240 \\
(0.74)\end{array}$ & $\begin{array}{l}0.0037 \\
(0.24)\end{array}$ & $\begin{array}{l}0.0004 \\
(0.03)\end{array}$ \\
\hline Age: $65+$ & $\begin{array}{l}0.0154 \\
(1.25)\end{array}$ & $\begin{array}{l}0.0338 \\
(3.00)^{*}\end{array}$ & $\begin{array}{l}0.0403 \\
(1.50)\end{array}$ & $\begin{array}{l}0.0226 \\
(0.75)\end{array}$ & $\begin{array}{l}0.0090 \\
(0.63)\end{array}$ & $\begin{array}{l}-0.0065 \\
(0.43)\end{array}$ \\
\hline Blacks & $\begin{array}{l}0.0001 \\
(0.10)\end{array}$ & $\begin{array}{l}0.0023 \\
(1.66)^{* * *}\end{array}$ & $\begin{array}{l}0.0025 \\
(1.01)\end{array}$ & $\begin{array}{c}0.0057 \\
(2.03)^{* *}\end{array}$ & $\begin{array}{l}-0.0018 \\
(1.13)\end{array}$ & $\begin{array}{l}-0.0001 \\
(0.04)\end{array}$ \\
\hline Hispanic & $\begin{array}{l}-0.0063 \\
(4.39)^{*}\end{array}$ & $\begin{array}{l}-0.0065 \\
(4.21)^{*}\end{array}$ & $\begin{array}{l}-0.0036 \\
(1.36)\end{array}$ & $\begin{array}{l}-0.0028 \\
(0.96)\end{array}$ & $\begin{array}{l}-0.0085 \\
(4.33)^{*}\end{array}$ & $\begin{array}{l}-0.0087 \\
(4.15)^{*}\end{array}$ \\
\hline Education: $9-11$ years & $\begin{array}{l}-0.0227 \\
(6.84)^{*}\end{array}$ & $\begin{array}{l}-0.0222 \\
(6.21)^{*}\end{array}$ & $\begin{array}{l}-0.0256 \\
(3.68)^{*}\end{array}$ & $\begin{array}{l}-0.0180 \\
(2.34)^{* *}\end{array}$ & $\begin{array}{l}-0.0216 \\
(5.59)^{*}\end{array}$ & $\begin{array}{l}-0.0224 \\
(5.47)^{*}\end{array}$ \\
\hline Education: H.S. diploma & $\begin{array}{l}0.0015 \\
(0.54)\end{array}$ & $\begin{array}{l}0.0097 \\
(3.26)^{*}\end{array}$ & $\begin{array}{l}-0.0023 \\
(0.40)\end{array}$ & $\begin{array}{l}0.0013 \\
(0.20)\end{array}$ & $\begin{array}{l}0.0025 \\
(0.76)\end{array}$ & $\begin{array}{r}0.0115 \\
(3.36)^{*}\end{array}$ \\
\hline Education: Some college & $\begin{array}{l}-0.0119 \\
(2.10)^{* *}\end{array}$ & $\begin{array}{l}-0.0025 \\
(0.41)\end{array}$ & $\begin{array}{l}-0.0071 \\
(0.59)\end{array}$ & $\begin{array}{l}-0.0044 \\
(0.32)\end{array}$ & $\begin{array}{l}-0.0069 \\
(1.07)\end{array}$ & $\begin{array}{l}0.0032 \\
(0.47)\end{array}$ \\
\hline Education: Bachelor + & $\begin{array}{l}0.0456 \\
(7.85)^{*}\end{array}$ & $\begin{array}{c}0.0732 \\
(12.01)^{*}\end{array}$ & $\begin{array}{l}0.0613 \\
(5.60)^{*}\end{array}$ & $\begin{array}{l}0.1138 \\
(9.98)^{*}\end{array}$ & $\begin{array}{l}0.0364 \\
(5.04)^{*}\end{array}$ & $\begin{array}{r}0.0574 \\
(7.62)^{*}\end{array}$ \\
\hline $\begin{array}{l}\text { Education: Public } \\
\text { elementary }\end{array}$ & $\begin{array}{l}-0.0000 \\
(1.42)\end{array}$ & $\begin{array}{l}-0.0000 \\
(3.05)^{*}\end{array}$ & $\begin{array}{l}-0.0000 \\
(1.67)^{* * *}\end{array}$ & $\begin{array}{l}-0.0000 \\
(3.33)^{*}\end{array}$ & $\begin{array}{l}0.0000 \\
(1.09)\end{array}$ & $\begin{array}{l}0.0000 \\
(0.40)\end{array}$ \\
\hline Education: Public nursery & $\begin{array}{l}-0.0000 \\
(0.49)\end{array}$ & $\begin{array}{l}-0.0000 \\
(1.18)\end{array}$ & $\begin{array}{l}0.0000 \\
(0.23)\end{array}$ & $\begin{array}{l}-0.0000 \\
(0.42)\end{array}$ & $\begin{array}{l}-0.0000 \\
(0.80)\end{array}$ & $\begin{array}{l}-0.0000 \\
(0.69)\end{array}$ \\
\hline $\begin{array}{l}\text { Education: Private } \\
\text { elementary }\end{array}$ & $\begin{array}{l}0.0000 \\
(0.29)\end{array}$ & $\begin{array}{l}0.0000 \\
(0.39)\end{array}$ & $\begin{array}{l}0.0000 \\
(0.12)\end{array}$ & $\begin{array}{l}0.0000 \\
(0.15)\end{array}$ & $\begin{array}{l}0.0000 \\
(2.58)^{*}\end{array}$ & $\begin{array}{l}0.0000 \\
(2.64)^{*}\end{array}$ \\
\hline Education: Private nursery & $\begin{array}{l}0.0000 \\
(3.67)^{*}\end{array}$ & $\begin{array}{l}0.0000 \\
(4.25)^{*}\end{array}$ & $\begin{array}{l}0.0000 \\
(2.86)^{*}\end{array}$ & $\begin{array}{l}0.0000 \\
(3.59)^{*}\end{array}$ & $\begin{array}{l}-0.0000 \\
(0.53)\end{array}$ & $\begin{array}{l}-0.0000 \\
(0.61)\end{array}$ \\
\hline Housing & $\begin{array}{l}-0.0000 \\
(0.14)\end{array}$ & $\begin{array}{l}0.0000 \\
(1.33)\end{array}$ & $\begin{array}{l}-0.0000 \\
(0.15)\end{array}$ & $\begin{array}{l}0.0000 \\
(1.18)\end{array}$ & $\begin{array}{l}-0.0000 \\
(0.90)\end{array}$ & $\begin{array}{l}-0.0000 \\
(0.14)\end{array}$ \\
\hline $\begin{array}{l}\text { Federal government } \\
\text { employment }\end{array}$ & $\begin{array}{l}-0.0145 \\
(2.99)^{*}\end{array}$ & $\begin{array}{l}-0.0222 \\
(4.26)^{*}\end{array}$ & $\begin{array}{l}-0.0108 \\
(1.12)\end{array}$ & $\begin{array}{l}-0.0318 \\
(2.99)^{*}\end{array}$ & $\begin{array}{l}-0.0135 \\
(2.34)^{* *}\end{array}$ & $\begin{array}{l}-0.0171 \\
(2.79)^{*}\end{array}$ \\
\hline $\begin{array}{l}\text { State government } \\
\text { employment }\end{array}$ & $\begin{array}{l}-0.0029 \\
(0.76)\end{array}$ & $\begin{array}{l}-0.0163 \\
(4.07)^{*}\end{array}$ & $\begin{array}{l}-0.0058 \\
(0.85)\end{array}$ & $\begin{array}{l}-0.0263 \\
(3.51)^{*}\end{array}$ & $\begin{array}{l}0.0028 \\
(0.61)\end{array}$ & $\begin{array}{l}-0.0071 \\
(1.65)^{* * *}\end{array}$ \\
\hline $\begin{array}{l}\text { Local government } \\
\text { employment }\end{array}$ & $\begin{array}{l}-0.0219 \\
(4.52)^{*}\end{array}$ & $\begin{array}{l}-0.0204 \\
(3.91)^{*}\end{array}$ & $\begin{array}{l}-0.0161 \\
(1.52)\end{array}$ & $\begin{array}{l}-0.0230 \\
(1.95) * * *\end{array}$ & $\begin{array}{l}-0.0165 \\
(2.94)^{*}\end{array}$ & $\begin{array}{l}-0.0128 \\
(2.15)^{* * *}\end{array}$ \\
\hline
\end{tabular}

\footnotetext{
3 All RHS variables are initial values from 1970. Also, state dummies were employed in all regressions.

4 All dollar values are in real 1992 dollars.
} 
Table A1. Growth Equation Estimates: Entire United States (continued)

\begin{tabular}{|c|c|c|c|c|c|c|}
\hline \multirow[b]{2}{*}{$\underline{\text { RHS Variables }}$} & \multicolumn{2}{|c|}{ All } & \multicolumn{2}{|c|}{ Metro } & \multicolumn{2}{|c|}{ Non-Metro _ } \\
\hline & $\underline{\text { OLS }}$ & $\underline{2 S L S}$ & $\underline{\text { OLS }}$ & $\underline{2 S L S}$ & $\underline{\text { OLS }}$ & $\underline{2 S L S}$ \\
\hline Self-employment & $\begin{array}{l}0.0060 \\
(1.87)^{* * *}\end{array}$ & $\begin{array}{l}0.0005 \\
(0.15)\end{array}$ & $\begin{array}{l}0.0024 \\
(0.36)\end{array}$ & $\begin{array}{l}-0.0087 \\
(1.17)\end{array}$ & $\begin{array}{l}0.0086 \\
(2.31)^{* *}\end{array}$ & $\begin{array}{l}0.0050 \\
(1.27)\end{array}$ \\
\hline Agriculture & $\begin{array}{l}-0.0115 \\
(1.86)^{* * *}\end{array}$ & $\begin{array}{l}-0.0037 \\
(0.56)\end{array}$ & $\begin{array}{l}0.0036 \\
(0.33)\end{array}$ & $\begin{array}{l}0.0072 \\
(0.57)\end{array}$ & $\begin{array}{l}-0.0159 \\
(2.09)^{* *}\end{array}$ & $\begin{array}{l}-0.0071 \\
(2.51)^{* *}\end{array}$ \\
\hline Communications & $\begin{array}{l}-0.0261 \\
(2.69)^{*}\end{array}$ & $\begin{array}{l}-0.0156 \\
(1.78)^{* * *}\end{array}$ & $\begin{array}{l}0.0076 \\
(0.36)\end{array}$ & $\begin{array}{l}-0.0056 \\
(0.24)\end{array}$ & $\begin{array}{l}-0.0283 \\
(2.58)^{*}\end{array}$ & $\begin{array}{l}-0.0191 \\
(1.66)^{* * *}\end{array}$ \\
\hline Construction & $\begin{array}{l}0.0151 \\
(1.27)\end{array}$ & $\begin{array}{l}0.0093 \\
(2.21)^{* *}\end{array}$ & $\begin{array}{r}0.0593 \\
(4.68)^{*}\end{array}$ & $\begin{array}{l}0.0466 \\
(3.31)^{*}\end{array}$ & $\begin{array}{l}0.0028 \\
(0.34)\end{array}$ & $\begin{array}{l}0.0011 \\
(0.12)\end{array}$ \\
\hline $\begin{array}{l}\text { Finance, insurance } \\
\text { and real estate }\end{array}$ & $\begin{array}{r}0.0678 \\
(5.77)^{*}\end{array}$ & $\begin{array}{r}0.0777 \\
(6.16)^{*}\end{array}$ & $\begin{array}{l}0.0624 \\
(2.93)^{*}\end{array}$ & $\begin{array}{l}0.0633 \\
(2.67)^{*}\end{array}$ & $\begin{array}{r}0.0691 \\
(4.77)^{*}\end{array}$ & $\begin{array}{r}0.0778 \\
(5.08)^{*}\end{array}$ \\
\hline $\begin{array}{l}\text { Manufacturing - } \\
\text { durables }\end{array}$ & $\begin{array}{l}0.0017 \\
(0.30)\end{array}$ & $\begin{array}{l}-0.0034 \\
(0.54)\end{array}$ & $\begin{array}{l}0.0174 \\
(1.61)\end{array}$ & $\begin{array}{l}-0.0030 \\
(0.25)\end{array}$ & $\begin{array}{l}-0.0028 \\
(0.40)\end{array}$ & $\begin{array}{l}-0.0040 \\
(0.53)\end{array}$ \\
\hline $\begin{array}{l}\text { Manufacturing - } \\
\text { nondurables }\end{array}$ & $\begin{array}{l}-0.0073 \\
(1.22)\end{array}$ & $\begin{array}{l}-0.0131 \\
(2.04)^{* *}\end{array}$ & $\begin{array}{l}0.0030 \\
(0.27)\end{array}$ & $\begin{array}{l}-0.0157 \\
(1.30)\end{array}$ & $\begin{array}{l}-0.0100 \\
(1.38)\end{array}$ & $\begin{array}{l}-0.0119 \\
(1.54)\end{array}$ \\
\hline Mining & $\begin{array}{l}-0.0111 \\
(1.79)^{* * *}\end{array}$ & $\begin{array}{l}-0.0145 \\
(2.18)^{* *}\end{array}$ & $\begin{array}{l}0.0045 \\
(0.36)\end{array}$ & $\begin{array}{l}-0.0227 \\
(1.66)^{* * *}\end{array}$ & $\begin{array}{l}-0.0152 \\
(2.02)^{* *}\end{array}$ & $\begin{array}{l}-0.0146 \\
(1.84)^{* * *}\end{array}$ \\
\hline Retail & $\begin{array}{l}-0.0123 \\
(1.77)^{* * *}\end{array}$ & $\begin{array}{l}-0.0182 \\
(2.45)^{* *}\end{array}$ & $\begin{array}{l}-0.0095 \\
(0.73)\end{array}$ & $\begin{array}{l}-0.0286 \\
(1.99)^{* *}\end{array}$ & $\begin{array}{l}-0.0116 \\
(1.38)\end{array}$ & $\begin{array}{l}-0.0123 \\
(1.39)\end{array}$ \\
\hline $\begin{array}{l}\text { Business and repair } \\
\text { services }\end{array}$ & $\begin{array}{l}0.0024 \\
(0.20)\end{array}$ & $\begin{array}{l}0.0079 \\
(0.63)\end{array}$ & $\begin{array}{l}0.0199 \\
(0.83)\end{array}$ & $\begin{array}{l}0.0192 \\
(0.71)\end{array}$ & $\begin{array}{l}-0.0075 \\
(0.54)\end{array}$ & $\begin{array}{l}-0.0072 \\
(0.50)\end{array}$ \\
\hline Educational services & $\begin{array}{l}-0.0138 \\
(1.72)^{* * *}\end{array}$ & $\begin{array}{l}-0.0334 \\
(3.90)^{*}\end{array}$ & $\begin{array}{l}-0.0193 \\
(1.65)^{* * *}\end{array}$ & $\begin{array}{l}-0.0513 \\
(4.00)^{*}\end{array}$ & $\begin{array}{l}0.0034 \\
(0.29)\end{array}$ & $\begin{array}{l}-0.0105 \\
(0.84)\end{array}$ \\
\hline $\begin{array}{l}\text { Professional related } \\
\text { services }\end{array}$ & $\begin{array}{l}0.0002 \\
(0.20)\end{array}$ & $\begin{array}{l}0.0199 \\
(1.30)\end{array}$ & $\begin{array}{l}0.0048 \\
(0.36)\end{array}$ & $\begin{array}{l}-0.0024 \\
(0.16)\end{array}$ & $\begin{array}{l}-0.0185 \\
(1.47)\end{array}$ & $\begin{array}{l}-0.0173 \\
(1.30)\end{array}$ \\
\hline Health services & $\begin{array}{l}0.0048 \\
(0.57)\end{array}$ & $\begin{array}{l}0.0028 \\
(0.31)\end{array}$ & $\begin{array}{l}0.0075 \\
(0.59)\end{array}$ & $\begin{array}{l}-0.0011 \\
(0.08)\end{array}$ & $\begin{array}{l}0.0194 \\
(1.62)\end{array}$ & $\begin{array}{l}0.0216 \\
(1.71)^{* * * *}\end{array}$ \\
\hline Personal services & $\begin{array}{l}0.0268 \\
(3.39)^{*}\end{array}$ & $\begin{array}{l}0.0304 \\
(3.57)^{*}\end{array}$ & $\begin{array}{l}0.0206 \\
(1.36)\end{array}$ & $\begin{array}{l}0.0187 \\
(1.11)\end{array}$ & $\begin{array}{r}0.0322 \\
(3.44)^{*}\end{array}$ & $\begin{array}{l}0.0385 \\
(3.89)^{*}\end{array}$ \\
\hline $\begin{array}{l}\text { Entertainment and } \\
\text { recreational services }\end{array}$ & $\begin{array}{l}0.0428 \\
(2.79)^{*}\end{array}$ & $\begin{array}{l}0.0477 \\
(2.89)^{*}\end{array}$ & $\begin{array}{c}0.0744 \\
(2.44)^{* *}\end{array}$ & $\begin{array}{l}0.0609 \\
(1.79)^{* * *}\end{array}$ & $\begin{array}{l}0.0326 \\
(1.84)^{* * *}\end{array}$ & $\begin{array}{l}0.0399 \\
(2.13)^{* *}\end{array}$ \\
\hline Transportation & $\begin{array}{l}-0.0072 \\
(0.90)\end{array}$ & $\begin{array}{l}-0.0167 \\
(1.96)^{* *}\end{array}$ & $\begin{array}{c}0.0263 \\
(1.73)^{* * *}\end{array}$ & $\begin{array}{l}0.0157 \\
(0.93)\end{array}$ & $\begin{array}{l}-0.0159 \\
(1.66)^{* * *}\end{array}$ & $\begin{array}{l}-0.0214 \\
(2.12)^{* *}\end{array}$ \\
\hline Wholesale trade & $\begin{array}{l}0.0425 \\
(4.31)^{*}\end{array}$ & $\begin{array}{l}0.0422 \\
(3.98)^{*}\end{array}$ & $\begin{array}{l}0.0214 \\
(1.24)\end{array}$ & $\begin{array}{l}0.0050 \\
(0.26)\end{array}$ & $\begin{array}{l}0.0436 \\
(3.57)^{*}\end{array}$ & $\begin{array}{l}0.0477 \\
(3.69)^{*}\end{array}$ \\
\hline Poverty & $\begin{array}{l}-0.0239 \\
(9.27)^{*}\end{array}$ & $\begin{array}{l}-0.0496 \\
(20.20)^{*}\end{array}$ & $\begin{array}{l}-0.0162 \\
(2.80)^{*}\end{array}$ & $\begin{array}{l}-0.0552 \\
(9.90)^{*}\end{array}$ & $\begin{array}{l}-0.0251 \\
(8.57)^{*}\end{array}$ & $\begin{array}{l}-0.0460 \\
(16.53)^{*}\end{array}$ \\
\hline Metro area, 1970 & $\begin{array}{l}0.0010 \\
(3.06)^{*}\end{array}$ & $\begin{array}{l}0.0014 \\
(3.60)^{*}\end{array}$ & $\begin{array}{l}0.0005 \\
(1.04)\end{array}$ & $\begin{array}{l}0.0006 \\
(1.02)\end{array}$ & $\begin{array}{l}-0.0000 \\
(0.11)\end{array}$ & $\begin{array}{l}0.0000 \\
(0.29)\end{array}$ \\
\hline \# Observations & 3,058 & 3,058 & 867 & 867 & 2,191 & 2,191 \\
\hline
\end{tabular}

$t$-statistics are reported in parentheses

\footnotetext{
* $\quad$ significant at $1 \%$ level

** significant at $5 \%$ level

*** significant at $10 \%$ level
} 
Table A2. Growth Equation Estimates: Great Lakes Region

\begin{tabular}{|c|c|c|c|c|c|c|}
\hline \multirow[b]{2}{*}{$\underline{\text { RHS Variables }}^{5}$} & \multicolumn{2}{|c|}{ All } & \multicolumn{2}{|c|}{ Metro } & \multicolumn{2}{|c|}{ Non-Metro } \\
\hline & $\underline{\text { OLS }}$ & $\underline{2 S L S}$ & $\underline{\text { OLS }}$ & $\underline{2 S L S}$ & $\underline{\text { OLS }}$ & 2SLS \\
\hline Constant & $\begin{array}{c}0.0127 \\
(2.54)^{* *}\end{array}$ & $\begin{array}{l}0.1212 \\
(6.78)^{*}\end{array}$ & $\begin{array}{l}-0.0226 \\
(0.24)\end{array}$ & $\begin{array}{l}0.1874 \\
(2.12)^{* *}\end{array}$ & $\begin{array}{c}0.1551 \\
(2.53)^{* *}\end{array}$ & $\begin{array}{l}0.2583 \\
(5.13)^{*}\end{array}$ \\
\hline $\begin{array}{l}\text { Log } 1970 \text { per capita } \\
\text { income }^{6}\end{array}$ & $\begin{array}{l}-0.0171 \\
(7.51)^{*}\end{array}$ & $\begin{array}{l}-0.0289 \\
(16.93)^{*}\end{array}$ & $\begin{array}{l}-0.0114 \\
(1.18)\end{array}$ & $\begin{array}{l}-0.0328 \\
(13.08)^{*}\end{array}$ & $\begin{array}{l}-0.0190 \\
(6.67)^{*}\end{array}$ & $\begin{array}{l}-0.0272 \\
(14.14)^{*}\end{array}$ \\
\hline Land area & $\begin{array}{l}0.0000 \\
(0.29)\end{array}$ & $\begin{array}{l}-0.0000 \\
(0.44)\end{array}$ & $\begin{array}{l}-0.0000 \\
(0.88)\end{array}$ & $\begin{array}{l}-0.0000 \\
(1.27)\end{array}$ & $\begin{array}{l}0.0000 \\
(1.42)\end{array}$ & $\begin{array}{l}0.0000 \\
(0.90)\end{array}$ \\
\hline Water area & $\begin{array}{l}0.0000 \\
(2.19)^{* * *}\end{array}$ & $\begin{array}{l}0.0000 \\
(2.03)^{* *}\end{array}$ & $\begin{array}{l}0.0000 \\
(0.45)\end{array}$ & $\begin{array}{l}0.0000 \\
(0.43)\end{array}$ & $\begin{array}{l}0.0000 \\
(2.07)^{* *}\end{array}$ & $\begin{array}{l}0.0000 \\
(2.08)^{* *}\end{array}$ \\
\hline Age: $5-13$ years & $\begin{array}{c}0.1082 \\
(2.02)^{* *}\end{array}$ & $\begin{array}{l}0.0589 \\
(1.80)^{* * *}\end{array}$ & $\begin{array}{l}0.1649 \\
(1.53)\end{array}$ & $\begin{array}{c}0.1393 \\
(1.81)^{* * *}\end{array}$ & $\begin{array}{l}0.0613 \\
(0.92)\end{array}$ & $\begin{array}{l}0.0205 \\
(0.31)\end{array}$ \\
\hline Age: $14-17$ years & $\begin{array}{l}0.1266 \\
(2.91)^{*}\end{array}$ & $\begin{array}{c}0.0788 \\
(1.79)^{* * *}\end{array}$ & $\begin{array}{l}0.2655 \\
(2.78)^{*}\end{array}$ & $\begin{array}{c}0.2593 \\
(2.48)^{* *}\end{array}$ & $\begin{array}{l}0.0808 \\
(1.54)\end{array}$ & $\begin{array}{l}0.0417 \\
(0.81)\end{array}$ \\
\hline Age: $18-64$ years & $\begin{array}{l}0.0597 \\
(1.54)\end{array}$ & $\begin{array}{l}0.0228 \\
(0.58)\end{array}$ & $\begin{array}{l}0.1186 \\
(1.45)\end{array}$ & $\begin{array}{l}0.1288 \\
(1.43)\end{array}$ & $\begin{array}{l}0.0378 \\
(0.77)\end{array}$ & $\begin{array}{l}0.0051 \\
(0.11)\end{array}$ \\
\hline Age: $65+$ & $\begin{array}{l}0.0291 \\
(0.79)\end{array}$ & $\begin{array}{l}-0.0119 \\
(0.32)\end{array}$ & $\begin{array}{l}0.1133 \\
(1.45)\end{array}$ & $\begin{array}{l}0.1145 \\
(1.34)\end{array}$ & $\begin{array}{l}0.0054 \\
(0.12)\end{array}$ & $\begin{array}{l}-0.0284 \\
(0.63)\end{array}$ \\
\hline Blacks & $\begin{array}{l}-0.0185 \\
(2.89)^{*}\end{array}$ & $\begin{array}{l}-0.0157 \\
(2.46)^{* *}\end{array}$ & $\begin{array}{l}-0.0220 \\
(2.03)^{* *}\end{array}$ & $\begin{array}{l}-0.0224 \\
(1.88)^{* * *}\end{array}$ & $\begin{array}{l}-0.0078 \\
(0.94)\end{array}$ & $\begin{array}{l}-0.0060 \\
(0.72)\end{array}$ \\
\hline Hispanic & $\begin{array}{l}-0.0316 \\
(1.49)\end{array}$ & $\begin{array}{l}-0.0201 \\
(0.92)\end{array}$ & $\begin{array}{l}-0.0231 \\
(0.82)\end{array}$ & $\begin{array}{l}-0.0022 \\
(0.07)\end{array}$ & $\begin{array}{l}-0.0452 \\
(1.30)\end{array}$ & $\begin{array}{l}-0.0360 \\
(1.03)\end{array}$ \\
\hline Education: 9-11 years & $\begin{array}{l}-0.0448 \\
(5.11)^{*}\end{array}$ & $\begin{array}{l}-0.0438 \\
(4.84)^{*}\end{array}$ & $\begin{array}{l}-0.0653 \\
(3.14)^{*}\end{array}$ & $\begin{array}{l}-0.0720 \\
(3.16)^{*}\end{array}$ & $\begin{array}{l}-0.0398 \\
(3.69)^{*}\end{array}$ & $\begin{array}{l}-0.0395 \\
(3.62)^{*}\end{array}$ \\
\hline Education: H.S. diploma & $\begin{array}{l}-0.0158 \\
(2.89)^{*}\end{array}$ & $\begin{array}{l}-0.0082 \\
(1.51)\end{array}$ & $\begin{array}{l}-0.0001 \\
(0.10)\end{array}$ & $\begin{array}{l}0.0056 \\
(0.44)\end{array}$ & $\begin{array}{l}-0.0177 \\
(2.51)^{* *}\end{array}$ & $\begin{array}{l}-0.0116 \\
(1.70)^{* * *}\end{array}$ \\
\hline Education: Some college & $\begin{array}{l}0.0306 \\
(2.01)^{* *}\end{array}$ & $\begin{array}{c}0.0393 \\
(2.51)^{* *}\end{array}$ & $\begin{array}{l}-0.0271 \\
(0.80)\end{array}$ & $\begin{array}{l}-0.0279 \\
(0.75)\end{array}$ & $\begin{array}{l}0.0358 \\
(1.90)^{* * *}\end{array}$ & $\begin{array}{c}0.0451 \\
(2.38)^{* *}\end{array}$ \\
\hline Education: Bachelor + & $\begin{array}{l}0.0420 \\
(2.91)^{*}\end{array}$ & $\begin{array}{c}0.0613 \\
(4.25)^{*}\end{array}$ & $\begin{array}{c}0.0625 \\
(2.08)^{* *}\end{array}$ & $\begin{array}{c}0.1066 \\
(3.41)^{*}\end{array}$ & $\begin{array}{c}0.0468 \\
(2.44)^{* *}\end{array}$ & $\begin{array}{l}0.0546 \\
(2.84)^{*}\end{array}$ \\
\hline $\begin{array}{l}\text { Education: Public } \\
\text { elementary }\end{array}$ & $\begin{array}{l}0.0000 \\
(1.74)^{* * *}\end{array}$ & $\begin{array}{l}0.0000 \\
(1.70)^{* * *}\end{array}$ & $\begin{array}{l}0.0000 \\
(0.07)\end{array}$ & $\begin{array}{l}0.0000 \\
(0.44)\end{array}$ & $\begin{array}{l}0.0000 \\
(0.66)\end{array}$ & $\begin{array}{l}0.0000 \\
(0.86)\end{array}$ \\
\hline Education: Public nursery & $\begin{array}{l}0.0000 \\
(0.89)\end{array}$ & $\begin{array}{l}0.0000 \\
(0.92)\end{array}$ & $\begin{array}{l}0.0000 \\
(1.14)\end{array}$ & $\begin{array}{l}0.0000 \\
(1.49)\end{array}$ & $\begin{array}{l}0.0000 \\
(0.80)\end{array}$ & $\begin{array}{l}0.0000 \\
(0.79)\end{array}$ \\
\hline $\begin{array}{l}\text { Education: Private } \\
\text { elementary }\end{array}$ & $\begin{array}{l}0.0000 \\
(1.14)\end{array}$ & $\begin{array}{l}0.0000 \\
(0.62)\end{array}$ & $\begin{array}{l}0.0000 \\
(0.32)\end{array}$ & $\begin{array}{l}-0.0000 \\
(0.01)\end{array}$ & $\begin{array}{l}0.0000 \\
(1.57)\end{array}$ & $\begin{array}{l}0.0000 \\
(1.26)\end{array}$ \\
\hline Education: Private nursery & $\begin{array}{l}-0.0000 \\
(0.35)\end{array}$ & $\begin{array}{l}-0.0000 \\
(0.09)\end{array}$ & $\begin{array}{l}-0.0000 \\
(0.57)\end{array}$ & $\begin{array}{l}-0.0000 \\
(0.58)\end{array}$ & $\begin{array}{l}0.0000 \\
(0.43)\end{array}$ & $\begin{array}{l}0.0000 \\
(0.49)\end{array}$ \\
\hline Housing & $\begin{array}{l}-0.0000 \\
(1.82)^{* * *}\end{array}$ & $\begin{array}{l}-0.0000 \\
(2.03)^{* *}\end{array}$ & $\begin{array}{l}-0.0000 \\
(0.31)\end{array}$ & $\begin{array}{l}-0.0000 \\
(0.47)\end{array}$ & $\begin{array}{l}-0.0000 \\
(1.55)\end{array}$ & $\begin{array}{l}-0.0000 \\
(1.60)\end{array}$ \\
\hline $\begin{array}{l}\text { Federal government } \\
\text { employment }\end{array}$ & $\begin{array}{l}-0.0001 \\
(0.01)\end{array}$ & $\begin{array}{l}-0.0043 \\
(0.30)\end{array}$ & $\begin{array}{l}0.0192 \\
(0.63)\end{array}$ & $\begin{array}{l}-0.0040 \\
(0.12)\end{array}$ & $\begin{array}{l}0.0063 \\
(0.34)\end{array}$ & $\begin{array}{l}0.0078 \\
(0.42)\end{array}$ \\
\hline $\begin{array}{l}\text { State government } \\
\text { employment }\end{array}$ & $\begin{array}{l}-0.0059 \\
(0.68)\end{array}$ & $\begin{array}{l}-0.0148 \\
(1.68)^{* * *}\end{array}$ & $\begin{array}{l}-0.0102 \\
(0.55)\end{array}$ & $\begin{array}{l}-0.0274 \\
(1.67)^{* * *}\end{array}$ & $\begin{array}{l}-0.0137 \\
(1.30)\end{array}$ & $\begin{array}{l}-0.0197 \\
(1.88)^{* * *}\end{array}$ \\
\hline $\begin{array}{l}\text { Local government } \\
\text { employment }\end{array}$ & $\begin{array}{l}-0.0256 \\
(2.21)^{* *}\end{array}$ & $\begin{array}{l}-0.0278 \\
(2.34)^{* *}\end{array}$ & $\begin{array}{l}-0.0714 \\
(1.99)^{* *}\end{array}$ & $\begin{array}{l}-0.0493 \\
(1.26)\end{array}$ & $\begin{array}{l}-0.0300 \\
(2.24)^{* *}\end{array}$ & $\begin{array}{l}-0.0303 \\
(2.23)^{* *}\end{array}$ \\
\hline
\end{tabular}

${ }^{5}$ All RHS variables are initial values from 1970. Also, state dummies were employed in all regressions.

${ }^{6}$ All dollar values are in real 1992 dollars. 
Table A2. Growth Equation Estimates: Great Lakes Region (continued)

\begin{tabular}{|c|c|c|c|c|c|c|}
\hline \multirow[b]{2}{*}{$\underline{\text { RHS Variables }}$} & \multicolumn{2}{|c|}{ All } & \multicolumn{2}{|c|}{ Metro } & \multicolumn{2}{|c|}{ Non-Metro } \\
\hline & $\underline{\text { OLS }}$ & 2SLS & $\underline{\text { OLS }}$ & 2SLS & $\underline{\text { OLS }}$ & 2SLS \\
\hline Self-employment & $\begin{array}{l}-0.0071 \\
(0.59)\end{array}$ & $\begin{array}{l}-0.0161 \\
(1.32)\end{array}$ & $\begin{array}{l}-0.1065 \\
(2.41)^{* *}\end{array}$ & $\begin{array}{l}-0.1556 \\
(3.30)^{*}\end{array}$ & $\begin{array}{l}-0.0030 \\
(0.23)\end{array}$ & $\begin{array}{l}-0.0078 \\
(0.53)\end{array}$ \\
\hline Agriculture & $\begin{array}{l}-0.0034 \\
(0.18)\end{array}$ & $\begin{array}{l}0.0051 \\
(0.26)\end{array}$ & $\begin{array}{l}0.0968 \\
(1.80)^{* * * *}\end{array}$ & $\begin{array}{l}0.1339 \\
(2.30)^{* *}\end{array}$ & $\begin{array}{l}0.0035 \\
(0.15)\end{array}$ & $\begin{array}{l}0.1226 \\
(0.50)\end{array}$ \\
\hline Communications & $\begin{array}{l}-0.0141 \\
(0.54)\end{array}$ & $\begin{array}{l}-0.0083 \\
(0.31)\end{array}$ & $\begin{array}{l}0.0305 \\
(0.53)\end{array}$ & $\begin{array}{l}0.0496 \\
(0.78)\end{array}$ & $\begin{array}{l}-0.0076 \\
(0.24)\end{array}$ & $\begin{array}{l}0.0014 \\
(0.04)\end{array}$ \\
\hline Construction & $\begin{array}{l}0.0044 \\
(0.24)\end{array}$ & $\begin{array}{l}0.0023 \\
(0.12)\end{array}$ & $\begin{array}{l}0.0968 \\
(2.29)^{* *}\end{array}$ & $\begin{array}{l}0.0964 \\
(2.08)^{* * *}\end{array}$ & $\begin{array}{l}0.0125 \\
(0.54)\end{array}$ & $\begin{array}{l}0.0156 \\
(0.66)\end{array}$ \\
\hline $\begin{array}{l}\text { Finance, insurance } \\
\text { and real estate }\end{array}$ & $\begin{array}{l}0.02684 \\
(1.01)\end{array}$ & $\begin{array}{c}0.0272 \\
(1.99)^{* *}\end{array}$ & $\begin{array}{l}0.0890 \\
(1.50)\end{array}$ & $\begin{array}{l}0.1034 \\
(1.59)\end{array}$ & $\begin{array}{l}0.0295 \\
(0.94)\end{array}$ & $\begin{array}{l}0.0331 \\
(1.04)\end{array}$ \\
\hline $\begin{array}{l}\text { Manufacturing - } \\
\text { durables }\end{array}$ & $\begin{array}{l}-0.0005 \\
(0.04)\end{array}$ & $\begin{array}{l}-0.0043 \\
(0.26)\end{array}$ & $\begin{array}{l}0.0369 \\
(1.10)\end{array}$ & $\begin{array}{l}0.0247 \\
(0.68)\end{array}$ & $\begin{array}{l}0.0116 \\
(0.55)\end{array}$ & $\begin{array}{l}0.0134 \\
(0.62)\end{array}$ \\
\hline $\begin{array}{l}\text { Manufacturing - } \\
\text { nondurables }\end{array}$ & $\begin{array}{l}-0.0033 \\
(0.21)\end{array}$ & $\begin{array}{l}-0.0078 \\
(0.48)\end{array}$ & $\begin{array}{l}0.0298 \\
(0.92)\end{array}$ & $\begin{array}{l}0.0184 \\
(0.52)\end{array}$ & $\begin{array}{l}0.0059 \\
(0.28)\end{array}$ & $\begin{array}{l}0.0077 \\
(0.36)\end{array}$ \\
\hline Mining & $\begin{array}{l}-0.0184 \\
(1.11)\end{array}$ & $\begin{array}{l}-0.0212 \\
(1.24)\end{array}$ & $\begin{array}{l}0.0275 \\
(0.59)\end{array}$ & $\begin{array}{l}0.0106 \\
(0.21)\end{array}$ & $\begin{array}{l}-0.0082 \\
(0.38)\end{array}$ & $\begin{array}{l}-0.0048 \\
(0.22)\end{array}$ \\
\hline Retail & $\begin{array}{l}-0.0137 \\
(0.74)\end{array}$ & $\begin{array}{l}-0.0159 \\
(0.83)\end{array}$ & $\begin{array}{l}0.0001 \\
(0.02)\end{array}$ & $\begin{array}{l}-0.0075 \\
(0.17)\end{array}$ & $\begin{array}{l}0.0075 \\
(0.31)\end{array}$ & $\begin{array}{l}0.0115 \\
(0.47)\end{array}$ \\
\hline $\begin{array}{l}\text { Business and repair } \\
\text { services }\end{array}$ & $\begin{array}{l}0.0462 \\
(1.14)\end{array}$ & $\begin{array}{l}0.0542 \\
(1.30)\end{array}$ & $\begin{array}{l}0.0291 \\
(0.35)\end{array}$ & $\begin{array}{l}0.0264 \\
(0.29)\end{array}$ & $\begin{array}{l}0.0430 \\
(0.85)\end{array}$ & $\begin{array}{l}0.0549 \\
(1.07)\end{array}$ \\
\hline Educational services & $\begin{array}{l}-0.0894 \\
(2.84)^{*}\end{array}$ & $\begin{array}{l}-0.1059 \\
(3.27)^{*}\end{array}$ & $\begin{array}{l}-0.1125 \\
(1.47)\end{array}$ & $\begin{array}{l}-0.1466 \\
(1.75)^{* * *}\end{array}$ & $\begin{array}{l}-0.0705 \\
(1.92)^{* * *}\end{array}$ & $\begin{array}{l}-0.0776 \\
(2.08)^{* *}\end{array}$ \\
\hline $\begin{array}{l}\text { Professional related } \\
\text { services }\end{array}$ & $\begin{array}{l}0.0623 \\
(1.98)^{* *}\end{array}$ & $\begin{array}{l}0.0637 \\
(1.92)^{* * *}\end{array}$ & $\begin{array}{l}0.1199 \\
(1.54)\end{array}$ & $\begin{array}{l}0.1086 \\
(1.27)\end{array}$ & $\begin{array}{l}0.0554 \\
(1.55)\end{array}$ & $\begin{array}{l}0.0578 \\
(1.59)\end{array}$ \\
\hline Health services & $\begin{array}{l}-0.0821 \\
(2.67)^{*}\end{array}$ & $\begin{array}{l}-0.0864 \\
(2.72)^{*}\end{array}$ & $\begin{array}{l}-0.1206 \\
(1.53)\end{array}$ & $\begin{array}{l}-0.1196 \\
(1.37)\end{array}$ & $\begin{array}{l}-0.0568 \\
(1.59)\end{array}$ & $\begin{array}{l}-0.0571 \\
(1.57)\end{array}$ \\
\hline Personal services & $\begin{array}{l}0.0173 \\
(0.68)\end{array}$ & $\begin{array}{l}0.0181 \\
(0.69)\end{array}$ & $\begin{array}{l}0.0840 \\
(1.15)\end{array}$ & $\begin{array}{l}0.0837 \\
(1.04)\end{array}$ & $\begin{array}{l}0.0408 \\
(1.31)\end{array}$ & $\begin{array}{l}0.0457 \\
(1.45)\end{array}$ \\
\hline $\begin{array}{l}\text { Entertainment and } \\
\text { recreational services }\end{array}$ & $\begin{array}{l}0.0902 \\
(1.16)\end{array}$ & $\begin{array}{l}0.1056 \\
(1.32)\end{array}$ & $\begin{array}{r}0.5941 \\
(3.49)^{*}\end{array}$ & $\begin{array}{l}0.5551 \\
(2.98)^{*}\end{array}$ & $\begin{array}{l}0.0023 \\
(0.03)\end{array}$ & $\begin{array}{l}0.0224 \\
(0.24)\end{array}$ \\
\hline Transportation & $\begin{array}{l}-0.0188 \\
(0.95)\end{array}$ & $\begin{array}{l}-0.0246 \\
(1.20)\end{array}$ & $\begin{array}{l}0.0029 \\
(0.08)\end{array}$ & $\begin{array}{l}-0.0217 \\
(0.53)\end{array}$ & $\begin{array}{l}-0.0092 \\
(0.35)\end{array}$ & $\begin{array}{l}-0.0069 \\
(0.26)\end{array}$ \\
\hline Wholesale trade & $\begin{array}{l}0.0618 \\
(2.60)^{*}\end{array}$ & $\begin{array}{l}0.0611 \\
(2.49)^{* *}\end{array}$ & $\begin{array}{l}0.1053 \\
(2.33)^{* *}\end{array}$ & $\begin{array}{l}0.1039 \\
(2.10)^{* *}\end{array}$ & $\begin{array}{l}0.0724 \\
(2.31)^{* *}\end{array}$ & $\begin{array}{l}0.0732 \\
(2.30)^{* *}\end{array}$ \\
\hline Poverty & $\begin{array}{l}-0.0212 \\
(2.60)^{*}\end{array}$ & $\begin{array}{l}-0.0397 \\
(5.23)^{*}\end{array}$ & $\begin{array}{l}-0.0017 \\
(0.07)\end{array}$ & $\begin{array}{l}-0.0395 \\
(1.47)\end{array}$ & $\begin{array}{l}-0.0275 \\
(2.85)^{*}\end{array}$ & $\begin{array}{l}-0.0396 \\
(4.48)^{*}\end{array}$ \\
\hline Metro area, 1970 & $\begin{array}{c}0.0001 \\
(1.80)^{* * * *}\end{array}$ & $\begin{array}{l}0.011 \\
(2.08)^{* *}\end{array}$ & $\begin{array}{l}0.0006 \\
(0.77)\end{array}$ & $\begin{array}{l}0.0011 \\
(1.15)\end{array}$ & $\begin{array}{l}0.0004 \\
(0.54)\end{array}$ & $\begin{array}{l}0.0004 \\
(0.47)\end{array}$ \\
\hline \# Observations & 435 & 435 & 140 & 140 & 295 & 295 \\
\hline
\end{tabular}


Table A3. Growth Equation Estimates: New England Region

\begin{tabular}{|c|c|c|c|c|c|c|}
\hline \multirow[b]{2}{*}{$\underline{\text { RHS Variables }^{7}}$} & \multicolumn{2}{|c|}{ All } & \multicolumn{2}{|c|}{ Metro } & \multicolumn{2}{|c|}{ Non-Metro } \\
\hline & $\underline{\text { OLS }}$ & 2SLS & OLS & 2SLS & OLS & $\underline{2 S L S}$ \\
\hline Constant & $\begin{array}{l}-0.0652 \\
(0.94)\end{array}$ & $\begin{array}{l}0.1790 \\
(2.64)^{*}\end{array}$ & $\begin{array}{l}-0.1943 \\
(1.51)\end{array}$ & $\begin{array}{l}0.0256 \\
(0.19)\end{array}$ & $\begin{array}{l}0.1436 \\
(1.57)\end{array}$ & $\begin{array}{r}0.3785 \\
(4.32)^{*}\end{array}$ \\
\hline $\begin{array}{l}\text { Log } 1970 \text { per capita } \\
\text { income }^{8}\end{array}$ & $\begin{array}{l}0.0030 \\
(0.73)\end{array}$ & $\begin{array}{l}-0.0264 \\
(10.86)^{*}\end{array}$ & $\begin{array}{l}0.0026 \\
(0.35)\end{array}$ & $\begin{array}{l}-0.0268 \\
(6.51)^{*}\end{array}$ & $\begin{array}{l}-0.0021 \\
(0.41)\end{array}$ & $\begin{array}{l}-0.0281 \\
(10.18)^{*}\end{array}$ \\
\hline Land area & $\begin{array}{l}-0.0000 \\
(1.39)\end{array}$ & $\begin{array}{l}-0.0000 \\
(1.55)\end{array}$ & $\begin{array}{l}-0.0000 \\
(1.33)\end{array}$ & $\begin{array}{l}-0.0000 \\
(1.27)\end{array}$ & $\begin{array}{l}-0.0000 \\
(0.34)\end{array}$ & $\begin{array}{l}-0.0000 \\
(0.30)\end{array}$ \\
\hline Water area & $\begin{array}{l}0.0000 \\
(1.99)^{* *}\end{array}$ & $\begin{array}{l}0.0000 \\
(1.91)^{* * *}\end{array}$ & $\begin{array}{l}0.0000 \\
(0.88)\end{array}$ & $\begin{array}{l}0.0000 \\
(1.32)\end{array}$ & $\begin{array}{l}0.0000 \\
(2.39)^{* *}\end{array}$ & $\begin{array}{l}0.0000 \\
(1.83)^{* * *}\end{array}$ \\
\hline Age: $5-13$ years & $\begin{array}{l}0.1692 \\
(1.85)^{* * * *}\end{array}$ & $\begin{array}{c}0.2059 \\
(2.02)^{* *}\end{array}$ & $\begin{array}{l}0.2502 \\
(1.50)\end{array}$ & $\begin{array}{l}0.3440 \\
(1.80)^{* * *}\end{array}$ & $\begin{array}{l}-0.0749 \\
(0.63)\end{array}$ & $\begin{array}{l}-0.0743 \\
(0.57)\end{array}$ \\
\hline Age: $14-17$ years & $\begin{array}{l}-0.0889 \\
(1.29)\end{array}$ & $\begin{array}{l}-0.0146 \\
(0.19)\end{array}$ & $\begin{array}{l}0.1423 \\
(1.32)\end{array}$ & $\begin{array}{l}0.1185 \\
(0.95)\end{array}$ & $\begin{array}{l}-0.1989 \\
(2.03)^{* *}\end{array}$ & $\begin{array}{l}-0.1085 \\
(1.01)\end{array}$ \\
\hline Age: $18-64$ years & $\begin{array}{l}0.0620 \\
(1.00)\end{array}$ & $\begin{array}{l}0.1169 \\
(1.70)^{* * *}\end{array}$ & $\begin{array}{l}0.1513 \\
(1.43)\end{array}$ & $\begin{array}{l}0.2072 \\
(1.71)^{* * *}\end{array}$ & $\begin{array}{l}-0.1075 \\
(1.32)\end{array}$ & $\begin{array}{l}-0.0728 \\
(0.81)\end{array}$ \\
\hline Age: $65+$ & $\begin{array}{l}0.0220 \\
(0.38)\end{array}$ & $\begin{array}{l}0.0345 \\
(0.53)\end{array}$ & $\begin{array}{l}0.0966 \\
(0.81)\end{array}$ & $\begin{array}{l}0.1462 \\
(1.07)\end{array}$ & $\begin{array}{l}-0.1016 \\
(1.38)\end{array}$ & $\begin{array}{l}-0.0997 \\
(1.22)\end{array}$ \\
\hline Blacks & $\begin{array}{l}-0.0097 \\
(1.38)\end{array}$ & $\begin{array}{l}0.0057 \\
(0.76)\end{array}$ & $\begin{array}{l}-0.0627 \\
(4.72)^{*}\end{array}$ & $\begin{array}{l}-0.0476 \\
(3.25)^{*}\end{array}$ & $\begin{array}{l}-0.0050 \\
(0.56)\end{array}$ & $\begin{array}{l}0.0062 \\
(0.64)\end{array}$ \\
\hline Hispanic & $\begin{array}{l}-0.0641 \\
(3.18)^{*}\end{array}$ & $\begin{array}{l}-0.0540 \\
(2.40)^{* *}\end{array}$ & $\begin{array}{l}-0.0967 \\
(4.67)^{*}\end{array}$ & $\begin{array}{l}-0.0723 \\
(3.18)^{*}\end{array}$ & $\begin{array}{l}-0.1458 \\
(1.98)^{* *}\end{array}$ & $\begin{array}{l}-0.1494 \\
(1.82)^{* * *}\end{array}$ \\
\hline Education: $9-11$ years & $\begin{array}{l}0.0098 \\
(0.73)\end{array}$ & $\begin{array}{l}0.0044 \\
(0.30)\end{array}$ & $\begin{array}{l}0.0642 \\
(2.56)^{* *}\end{array}$ & $\begin{array}{l}0.0409 \\
(1.68)^{* * *}\end{array}$ & $\begin{array}{l}-0.0045 \\
(0.27)\end{array}$ & $\begin{array}{l}-0.0031 \\
(0.17)\end{array}$ \\
\hline Education: H.S. diploma & $\begin{array}{l}-0.0128 \\
(1.25)\end{array}$ & $\begin{array}{l}-0.0199 \\
(1.74)^{* * *}\end{array}$ & $\begin{array}{l}-0.0427 \\
(2.60)^{*}\end{array}$ & $\begin{array}{l}-0.0505 \\
(2.68)^{*}\end{array}$ & $\begin{array}{l}-0.0107 \\
(0.85)\end{array}$ & $\begin{array}{l}-0.0141 \\
(1.01)\end{array}$ \\
\hline Education: Some college & $\begin{array}{l}-0.0113 \\
(0.45)\end{array}$ & $\begin{array}{l}-0.0156 \\
(0.55)\end{array}$ & $\begin{array}{l}0.0389 \\
(0.98)\end{array}$ & $\begin{array}{l}0.0472 \\
(1.04)\end{array}$ & $\begin{array}{l}0.0012 \\
(0.04)\end{array}$ & $\begin{array}{l}0.0028 \\
(0.08)\end{array}$ \\
\hline Education: Bachelor + & $\begin{array}{l}0.0570 \\
(2.62)^{*}\end{array}$ & $\begin{array}{l}0.1030 \\
(4.42)^{*}\end{array}$ & $\begin{array}{c}0.0997 \\
(2.38)^{* *}\end{array}$ & $\begin{array}{l}0.0998 \\
(2.06)^{* *}\end{array}$ & $\begin{array}{c}0.0662 \\
(2.41)^{* *}\end{array}$ & $\begin{array}{l}0.1205 \\
(4.29)^{*}\end{array}$ \\
\hline $\begin{array}{l}\text { Education: Public } \\
\text { elementary }\end{array}$ & $\begin{array}{l}-0.0000 \\
(0.63)\end{array}$ & $\begin{array}{l}-0.0000 \\
(2.96)^{*}\end{array}$ & $\begin{array}{l}0.0000 \\
(0.57)\end{array}$ & $\begin{array}{l}-0.0000 \\
(0.53)\end{array}$ & $\begin{array}{l}0.0000 \\
(1.60)\end{array}$ & $\begin{array}{l}0.0000 \\
(1.39)\end{array}$ \\
\hline Education: Public nursery & $\begin{array}{l}-0.0000 \\
(0.18)\end{array}$ & $\begin{array}{l}0.0000 \\
(0.06)\end{array}$ & $\begin{array}{l}0.0000 \\
(3.18)^{*}\end{array}$ & $\begin{array}{l}0.0000 \\
(3.94)^{*}\end{array}$ & $\begin{array}{l}-0.0000 \\
(0.98)\end{array}$ & $\begin{array}{l}-0.0000 \\
(0.70)\end{array}$ \\
\hline $\begin{array}{l}\text { Education: Private } \\
\text { elementary }\end{array}$ & $\begin{array}{l}-0.0000 \\
(2.21)^{* *}\end{array}$ & $\begin{array}{l}-0.0000 \\
(2.89)^{*}\end{array}$ & $\begin{array}{l}-0.0000 \\
(2.67)^{*}\end{array}$ & $\begin{array}{l}-0.0000 \\
(2.16)^{* *}\end{array}$ & $\begin{array}{l}0.0000 \\
(2.68)^{*}\end{array}$ & $\begin{array}{l}0.0000 \\
(2.41)^{* *}\end{array}$ \\
\hline Education: Private nursery & $\begin{array}{l}-0.0000 \\
(0.23)\end{array}$ & $\begin{array}{l}0.0000 \\
(2.01)^{* *}\end{array}$ & $\begin{array}{l}-0.0000 \\
(0.80)\end{array}$ & $\begin{array}{l}0.0000 \\
(0.55)\end{array}$ & $\begin{array}{l}-0.0000 \\
(1.54)\end{array}$ & $\begin{array}{l}-0.0000 \\
(1.71)^{* * *}\end{array}$ \\
\hline Housing & $\begin{array}{l}0.0000 \\
(1.87)^{* * *}\end{array}$ & $\begin{array}{l}0.0000 \\
(2.96)^{*}\end{array}$ & $\begin{array}{l}-0.0000 \\
(0.27)\end{array}$ & $\begin{array}{l}-0.0000 \\
(0.51)\end{array}$ & $\begin{array}{l}-0.0000 \\
(1.67)^{* * *}\end{array}$ & $\begin{array}{l}-0.0000 \\
(1.35)\end{array}$ \\
\hline $\begin{array}{l}\text { Federal government } \\
\text { employment }\end{array}$ & $\begin{array}{l}-0.0155 \\
(0.86)\end{array}$ & $\begin{array}{l}-0.0291 \\
(1.44)\end{array}$ & $\begin{array}{c}0.0554 \\
(1.71)^{* * *}\end{array}$ & $\begin{array}{l}0.0428 \\
(1.14)\end{array}$ & $\begin{array}{l}-0.0156 \\
(0.69)\end{array}$ & $\begin{array}{l}-0.0297 \\
(1.20)\end{array}$ \\
\hline $\begin{array}{l}\text { State government } \\
\text { employment }\end{array}$ & $\begin{array}{l}-0.0006 \\
(0.05)\end{array}$ & $\begin{array}{l}-0.0121 \\
(0.93)\end{array}$ & $\begin{array}{l}-0.0115 \\
(0.41)\end{array}$ & $\begin{array}{l}-0.0202 \\
(0.62)\end{array}$ & $\begin{array}{l}0.0088 \\
(0.66)\end{array}$ & $\begin{array}{l}0.0019 \\
(0.13)\end{array}$ \\
\hline $\begin{array}{l}\text { Local government } \\
\text { employment }\end{array}$ & $\begin{array}{l}-0.0191 \\
(0.88)\end{array}$ & $\begin{array}{l}-0.0412 \\
(1.70)^{* * *}\end{array}$ & $\begin{array}{l}-0.0350 \\
(0.63)\end{array}$ & $\begin{array}{l}-0.0877 \\
(1.41)\end{array}$ & $\begin{array}{l}-0.0113 \\
(0.41)\end{array}$ & $\begin{array}{l}-0.0352 \\
(1.13)\end{array}$ \\
\hline
\end{tabular}

${ }^{7}$ All RHS variables are initial values from 1970. Also, state dummies were employed in all regressions.

${ }^{8}$ All dollar values are in real 1992 dollars. 
Table A3. Growth Equation Estimates: New England Region (continued)

\begin{tabular}{|c|c|c|c|c|c|c|}
\hline \multirow[b]{2}{*}{$\underline{\text { RHS Variables }}$} & \multicolumn{2}{|c|}{ All } & \multicolumn{2}{|c|}{ Metro } & \multicolumn{2}{|c|}{ Non-Metro } \\
\hline & $\underline{\text { OLS }}$ & $\underline{2 S L S}$ & $\underline{\text { OLS }}$ & $\underline{2 S L S}$ & $\underline{\text { OLS }}$ & $\underline{2 S L S}$ \\
\hline Self-employment & $\begin{array}{l}-0.0167 \\
(0.68)\end{array}$ & $\begin{array}{l}0.0009 \\
(0.03)\end{array}$ & $\begin{array}{l}-0.0663 \\
(0.98)\end{array}$ & $\begin{array}{l}0.0236 \\
(0.32)\end{array}$ & $\begin{array}{l}-0.0315 \\
(1.03)\end{array}$ & $\begin{array}{l}-0.0285 \\
(0.84)\end{array}$ \\
\hline Agriculture & $\begin{array}{l}0.0110 \\
(0.40)\end{array}$ & $\begin{array}{l}0.0018 \\
(0.06)\end{array}$ & $\begin{array}{l}0.0500 \\
(0.63)\end{array}$ & $\begin{array}{l}0.0349 \\
(0.38)\end{array}$ & $\begin{array}{l}0.0233 \\
(0.69)\end{array}$ & $\begin{array}{l}0.0102 \\
(0.72)\end{array}$ \\
\hline Communications & $\begin{array}{l}0.0454 \\
(1.03)\end{array}$ & $\begin{array}{l}0.0801 \\
(1.68)^{* * *}\end{array}$ & $\begin{array}{l}0.0895 \\
(1.00)\end{array}$ & $\begin{array}{l}0.1569 \\
(1.84)^{* * *}\end{array}$ & $\begin{array}{l}0.0283 \\
(0.53)\end{array}$ & $\begin{array}{l}0.0385 \\
(0.65)\end{array}$ \\
\hline Construction & $\begin{array}{l}0.0447 \\
(1.74)^{* * *}\end{array}$ & $\begin{array}{l}0.0501 \\
(1.74)^{* * *}\end{array}$ & $\begin{array}{l}0.0568 \\
(0.73)\end{array}$ & $\begin{array}{l}0.0485 \\
(0.54)\end{array}$ & $\begin{array}{l}0.0355 \\
(1.15)\end{array}$ & $\begin{array}{l}0.0292 \\
(0.85)\end{array}$ \\
\hline $\begin{array}{l}\text { Finance, insurance } \\
\text { and real estate }\end{array}$ & $\begin{array}{l}0.0300 \\
(1.00)\end{array}$ & $\begin{array}{l}0.0243 \\
(1.72)^{* * *}\end{array}$ & $\begin{array}{l}-0.0286 \\
(0.56)\end{array}$ & $\begin{array}{l}0.0059 \\
(0.10)\end{array}$ & $\begin{array}{l}-0.0475 \\
(0.97)\end{array}$ & $\begin{array}{l}-0.0488 \\
(0.90)\end{array}$ \\
\hline $\begin{array}{l}\text { Manufacturing - } \\
\text { durables }\end{array}$ & $\begin{array}{l}-0.0165 \\
(0.83)\end{array}$ & $\begin{array}{l}-0.0223 \\
(1.02)\end{array}$ & $\begin{array}{l}0.0122 \\
(0.26)\end{array}$ & $\begin{array}{l}0.0305 \\
(0.57)\end{array}$ & $\begin{array}{l}-0.0171 \\
(0.69)\end{array}$ & $\begin{array}{l}-0.0321 \\
(1.18)\end{array}$ \\
\hline $\begin{array}{l}\text { Manufacturing - } \\
\text { nondurables }\end{array}$ & $\begin{array}{l}-0.0125 \\
(0.62)\end{array}$ & $\begin{array}{l}-0.0228 \\
(1.01)\end{array}$ & $\begin{array}{l}0.0145 \\
(0.29)\end{array}$ & $\begin{array}{l}0.0322 \\
(0.56)\end{array}$ & $\begin{array}{l}-0.0125 \\
(0.51)\end{array}$ & $\begin{array}{l}-0.0332 \\
(1.23)\end{array}$ \\
\hline Mining & $\begin{array}{l}-0.0125 \\
(0.62)\end{array}$ & $\begin{array}{l}-0.0028 \\
(1.01)\end{array}$ & $\begin{array}{l}0.0269 \\
(0.39)\end{array}$ & $\begin{array}{l}0.0393 \\
(0.49)\end{array}$ & $\begin{array}{l}-0.0056 \\
(0.17)\end{array}$ & $\begin{array}{l}-0.0365 \\
(1.04)\end{array}$ \\
\hline Retail & $\begin{array}{l}-0.0457 \\
(1.80)^{* * * *}\end{array}$ & $\begin{array}{l}-0.0411 \\
(1.72)^{* * * *}\end{array}$ & $\begin{array}{l}-0.0544 \\
(0.87)\end{array}$ & $\begin{array}{l}-0.0416 \\
(0.57)\end{array}$ & $\begin{array}{l}-0.0276 \\
(0.88)\end{array}$ & $\begin{array}{l}-0.0321 \\
(0.92)\end{array}$ \\
\hline $\begin{array}{l}\text { Business and repair } \\
\text { services }\end{array}$ & $\begin{array}{l}-0.0039 \\
(0.07)\end{array}$ & $\begin{array}{l}0.0286 \\
(0.45)\end{array}$ & $\begin{array}{l}0.3452 \\
(2.96)^{*}\end{array}$ & $\begin{array}{l}0.3660 \\
(2.72)^{*}\end{array}$ & $\begin{array}{l}0.0157 \\
(0.23)\end{array}$ & $\begin{array}{l}0.0589 \\
(0.77)\end{array}$ \\
\hline Educational services & $\begin{array}{l}-0.0497 \\
(1.06)\end{array}$ & $\begin{array}{l}-0.0834 \\
(1.80)^{* * *}\end{array}$ & $\begin{array}{l}0.0195 \\
(0.14)\end{array}$ & $\begin{array}{l}-0.1429 \\
(0.95)\end{array}$ & $\begin{array}{l}-0.0923 \\
(1.76)^{* * *}\end{array}$ & $\begin{array}{l}-0.1084 \\
(1.86)^{* * *}\end{array}$ \\
\hline $\begin{array}{l}\text { Professional related } \\
\text { services }\end{array}$ & $\begin{array}{l}0.0252 \\
(0.51)\end{array}$ & $\begin{array}{l}0.0042 \\
(0.08)\end{array}$ & $\begin{array}{l}-0.0467 \\
(0.33)\end{array}$ & $\begin{array}{l}0.1126 \\
(0.71)\end{array}$ & $\begin{array}{l}0.0544 \\
(0.99)\end{array}$ & $\begin{array}{l}0.0036 \\
(0.06)\end{array}$ \\
\hline Health services & $\begin{array}{l}0.0092 \\
(0.20)\end{array}$ & $\begin{array}{l}0.0227 \\
(0.44)\end{array}$ & $\begin{array}{l}0.1522 \\
(1.08)\end{array}$ & $\begin{array}{l}0.0069 \\
(0.04)\end{array}$ & $\begin{array}{l}-0.0306 \\
(0.60)\end{array}$ & $\begin{array}{l}-0.0005 \\
(0.01)\end{array}$ \\
\hline Personal services & $\begin{array}{l}-0.0309 \\
(1.08)\end{array}$ & $\begin{array}{l}-0.0372 \\
(1.16)\end{array}$ & $\begin{array}{l}0.0884 \\
(0.75)\end{array}$ & $\begin{array}{l}0.0549 \\
(0.41)\end{array}$ & $\begin{array}{l}-0.0097 \\
(0.30)\end{array}$ & $\begin{array}{l}-0.0164 \\
(0.46)\end{array}$ \\
\hline $\begin{array}{l}\text { Entertainment and } \\
\text { recreational services }\end{array}$ & $\begin{array}{l}0.1946 \\
(1.87)^{* * *}\end{array}$ & $\begin{array}{l}0.2068 \\
(1.78)^{* * *}\end{array}$ & $\begin{array}{l}0.0918 \\
(0.45)\end{array}$ & $\begin{array}{l}0.2339 \\
(1.86)^{* * *}\end{array}$ & $\begin{array}{l}0.0062 \\
(0.05)\end{array}$ & $\begin{array}{l}-0.0688 \\
(0.48)\end{array}$ \\
\hline Transportation & $\begin{array}{l}0.0051 \\
(0.18)\end{array}$ & $\begin{array}{l}-0.0126 \\
(0.39)\end{array}$ & $\begin{array}{l}0.1234 \\
(1.73)^{* * *}\end{array}$ & $\begin{array}{l}0.1381 \\
(1.78)^{* * *}\end{array}$ & $\begin{array}{l}-0.0139 \\
(0.39)\end{array}$ & $\begin{array}{l}-0.0436 \\
(1.13)\end{array}$ \\
\hline Wholesale trade & $\begin{array}{l}0.0155 \\
(0.41)\end{array}$ & $\begin{array}{l}0.0065 \\
(0.15)\end{array}$ & $\begin{array}{l}0.0124 \\
(0.16)\end{array}$ & $\begin{array}{l}0.0553 \\
(0.63)\end{array}$ & $\begin{array}{l}0.0217 \\
(0.45)\end{array}$ & $\begin{array}{l}-0.0104 \\
(0.19)\end{array}$ \\
\hline Poverty & $\begin{array}{l}0.0233 \\
(1.20)\end{array}$ & $\begin{array}{l}-0.0518 \\
(2.83)^{*}\end{array}$ & $\begin{array}{l}0.1042 \\
(2.11)^{* *}\end{array}$ & $\begin{array}{l}-0.0120 \\
(0.27)\end{array}$ & $\begin{array}{l}-0.0086 \\
(0.39)\end{array}$ & $\begin{array}{l}-0.0641 \\
(2.97)^{*}\end{array}$ \\
\hline Metro area, 1970 & $\begin{array}{l}-0.0000 \\
(0.08)\end{array}$ & $\begin{array}{l}0.0002 \\
(0.31)\end{array}$ & $\begin{array}{l}0.0004 \\
(0.37)\end{array}$ & $\begin{array}{l}0.0000 \\
(0.06)\end{array}$ & $\begin{array}{l}-0.0000 \\
(0.17)\end{array}$ & $\begin{array}{l}-0.0000 \\
(0.10)\end{array}$ \\
\hline \# Observations & 244 & 244 & 90 & 90 & 154 & 154 \\
\hline
\end{tabular}


Table A4. Growth Equation Estimates: Plains Region

\begin{tabular}{|c|c|c|c|c|c|c|}
\hline \multirow[b]{2}{*}{$\underline{\text { RHS Variables }}^{9}$} & \multicolumn{2}{|c|}{ All } & \multicolumn{2}{|c|}{ Metro } & \multicolumn{2}{|c|}{ Non-Metro } \\
\hline & $\underline{\text { OLS }}$ & $\underline{2 S L S}$ & $\underline{\text { OLS }}$ & $\underline{2 S L S}$ & $\underline{\text { OLS }}$ & 2SLS \\
\hline Constant & $\begin{array}{l}0.1736 \\
(5.90)^{*}\end{array}$ & $\begin{array}{l}0.2508 \\
(9.38)^{*}\end{array}$ & $\begin{array}{l}0.0285 \\
(0.43)\end{array}$ & $\begin{array}{l}0.1280 \\
(1.79)^{* * *}\end{array}$ & $\begin{array}{l}0.1818 \\
(5.59)^{*}\end{array}$ & $\begin{array}{l}0.2955 \\
(9.83)^{*}\end{array}$ \\
\hline $\begin{array}{l}\text { Log } 1970 \text { per capita } \\
\text { income }^{10}\end{array}$ & $\begin{array}{l}-0.0181 \\
(12.25)^{*}\end{array}$ & $\begin{array}{l}-0.0266 \\
(5.84)^{*}\end{array}$ & $\begin{array}{l}-0.0077 \\
(2.05)^{* *}\end{array}$ & $\begin{array}{l}-0.0271 \\
(8.91)^{*}\end{array}$ & $\begin{array}{l}-0.0185 \\
(11.45)^{*}\end{array}$ & $\begin{array}{l}-0.0308 \\
(6.39)^{*}\end{array}$ \\
\hline Land area & $\begin{array}{l}-0.0000 \\
(0.48)\end{array}$ & $\begin{array}{l}-0.0000 \\
(0.39)\end{array}$ & $\begin{array}{l}-0.0000 \\
(1.00)\end{array}$ & $\begin{array}{l}-0.0000 \\
(0.36)\end{array}$ & $\begin{array}{l}-0.0000 \\
(0.38)\end{array}$ & $\begin{array}{l}-0.0000 \\
(0.25)\end{array}$ \\
\hline Water area & $\begin{array}{l}0.0000 \\
(1.53)\end{array}$ & $\begin{array}{l}0.0000 \\
(1.17)\end{array}$ & $\begin{array}{l}0.0000 \\
(1.69)^{* * *}\end{array}$ & $\begin{array}{l}0.0000 \\
(0.72)\end{array}$ & $\begin{array}{l}0.0000 \\
(1.47)\end{array}$ & $\begin{array}{l}0.0000 \\
(0.96)\end{array}$ \\
\hline Age: $5-13$ years & $\begin{array}{l}0.0176 \\
(0.55)\end{array}$ & $\begin{array}{l}0.0255 \\
(0.77)\end{array}$ & $\begin{array}{l}0.0911 \\
(1.10)\end{array}$ & $\begin{array}{c}0.2008 \\
(2.23)^{* *}\end{array}$ & $\begin{array}{l}-0.0033 \\
(0.10)\end{array}$ & $\begin{array}{l}0.0006 \\
(0.02)\end{array}$ \\
\hline Age: $14-17$ years & $\begin{array}{l}0.0395 \\
(1.27)\end{array}$ & $\begin{array}{l}0.0413 \\
(1.80)^{* * *}\end{array}$ & $\begin{array}{l}0.0512 \\
(0.72)\end{array}$ & $\begin{array}{l}0.0657 \\
(0.82)\end{array}$ & $\begin{array}{l}0.0213 \\
(0.62)\end{array}$ & $\begin{array}{l}0.0217 \\
(0.61)\end{array}$ \\
\hline Age: $18-64$ years & $\begin{array}{l}0.0021 \\
(0.09)\end{array}$ & $\begin{array}{l}0.0057 \\
(0.23)\end{array}$ & $\begin{array}{l}0.0660 \\
(1.01)\end{array}$ & $\begin{array}{c}0.1414 \\
(1.98)^{* *}\end{array}$ & $\begin{array}{l}-0.0162 \\
(0.60)\end{array}$ & $\begin{array}{l}-0.0164 \\
(0.58)\end{array}$ \\
\hline Age: $65+$ & $\begin{array}{l}-0.0059 \\
(0.26)\end{array}$ & $\begin{array}{l}-0.0130 \\
(0.56)\end{array}$ & $\begin{array}{l}0.0269 \\
(0.47)\end{array}$ & $\begin{array}{l}0.1046 \\
(1.70)^{* * *}\end{array}$ & $\begin{array}{l}-0.0168 \\
(0.66)\end{array}$ & $\begin{array}{l}-0.0337 \\
(1.27)\end{array}$ \\
\hline Blacks & $\begin{array}{l}0.0008 \\
(0.08)\end{array}$ & $\begin{array}{l}0.0024 \\
(0.22)\end{array}$ & $\begin{array}{l}-0.0206 \\
(1.31)\end{array}$ & $\begin{array}{l}-0.0281 \\
(1.95)^{* * *}\end{array}$ & $\begin{array}{l}0.0099 \\
(0.76)\end{array}$ & $\begin{array}{l}0.0141 \\
(1.03)\end{array}$ \\
\hline Hispanic & $\begin{array}{l}-0.0052 \\
(1.23)\end{array}$ & $\begin{array}{l}-0.0072 \\
(1.68)^{* * *}\end{array}$ & $\begin{array}{l}0.0012 \\
(0.14)\end{array}$ & $\begin{array}{l}-0.0001 \\
(0.01)\end{array}$ & $\begin{array}{l}-0.0030 \\
(0.60)\end{array}$ & $\begin{array}{l}-0.0074 \\
(1.39)\end{array}$ \\
\hline Education: 9-11 years & $\begin{array}{l}-0.0616 \\
(7.17)^{*}\end{array}$ & $\begin{array}{l}-0.0597 \\
(6.81)^{*}\end{array}$ & $\begin{array}{l}-0.0429 \\
(2.33)^{* *}\end{array}$ & $\begin{array}{l}-0.0489 \\
(2.35)^{* *}\end{array}$ & $\begin{array}{l}-0.0637 \\
(6.56)^{*}\end{array}$ & $\begin{array}{l}-0.0615 \\
(6.07)^{*}\end{array}$ \\
\hline Education: H.S. diploma & $\begin{array}{l}0.0099 \\
(1.85)^{* * *}\end{array}$ & $\begin{array}{l}0.0161 \\
(3.00)^{*}\end{array}$ & $\begin{array}{c}0.0312 \\
(2.54)^{* *}\end{array}$ & $\begin{array}{c}0.0343 \\
(2.47)^{* *}\end{array}$ & $\begin{array}{l}0.0051 \\
(0.84)\end{array}$ & $\begin{array}{c}0.0155 \\
(2.49)^{* *}\end{array}$ \\
\hline Education: Some college & $\begin{array}{l}-0.0310 \\
(3.36)^{*}\end{array}$ & $\begin{array}{l}-0.0281 \\
(3.00)^{*}\end{array}$ & $\begin{array}{l}-0.0036 \\
(0.17)\end{array}$ & $\begin{array}{l}-0.0088 \\
(0.37)\end{array}$ & $\begin{array}{l}-0.0278 \\
(2.70)^{*}\end{array}$ & $\begin{array}{l}-0.0224 \\
(2.09)^{* *}\end{array}$ \\
\hline Education: Bachelor + & $\begin{array}{l}0.0099 \\
(0.83)\end{array}$ & $\begin{array}{c}0.0207 \\
(1.71)^{* * *}\end{array}$ & $\begin{array}{l}0.0410 \\
(1.81)^{* * *}\end{array}$ & $\begin{array}{c}0.0765 \\
(3.15)^{*}\end{array}$ & $\begin{array}{l}-0.0082 \\
(0.59)\end{array}$ & $\begin{array}{l}0.0072 \\
(0.50)\end{array}$ \\
\hline $\begin{array}{l}\text { Education: Public } \\
\text { elementary }\end{array}$ & $\begin{array}{l}-0.0000 \\
(1.22)\end{array}$ & $\begin{array}{l}-0.0000 \\
(1.42)\end{array}$ & $\begin{array}{l}-0.0000 \\
(2.33)^{* *}\end{array}$ & $\begin{array}{l}-0.0000 \\
(2.37)^{* *}\end{array}$ & $\begin{array}{l}0.0000 \\
(0.56)\end{array}$ & $\begin{array}{l}0.0000 \\
(0.61)\end{array}$ \\
\hline Education: Public nursery & $\begin{array}{l}-0.0000 \\
(1.05)\end{array}$ & $\begin{array}{l}-0.0000 \\
(1.01)\end{array}$ & $\begin{array}{l}0.0000 \\
(0.51)\end{array}$ & $\begin{array}{l}0.0000 \\
(0.38)\end{array}$ & $\begin{array}{l}-0.0000 \\
(0.13)\end{array}$ & $\begin{array}{l}-0.0000 \\
(0.22)\end{array}$ \\
\hline $\begin{array}{l}\text { Education: Private } \\
\text { elementary }\end{array}$ & $\begin{array}{l}-0.0000 \\
(0.22)\end{array}$ & $\begin{array}{l}-0.0000 \\
(0.20)\end{array}$ & $\begin{array}{l}0.0000 \\
(0.43)\end{array}$ & $\begin{array}{l}0.0000 \\
(0.70)\end{array}$ & $\begin{array}{l}0.0000 \\
(1.24)\end{array}$ & $\begin{array}{l}0.0000 \\
(1.15)\end{array}$ \\
\hline Education: Private nursery & $\begin{array}{l}0.0000 \\
(0.97)\end{array}$ & $\begin{array}{l}0.0000 \\
(1.06)\end{array}$ & $\begin{array}{l}0.0000 \\
(0.16)\end{array}$ & $\begin{array}{l}-0.0000 \\
(0.13)\end{array}$ & $\begin{array}{l}0.0000 \\
(0.65)\end{array}$ & $\begin{array}{l}0.0000 \\
(0.77)\end{array}$ \\
\hline Housing & $\begin{array}{l}0.0000 \\
(1.41)\end{array}$ & $\begin{array}{l}0.0000 \\
(1.68)^{* * *}\end{array}$ & $\begin{array}{l}0.0000 \\
(2.16)^{* *}\end{array}$ & $\begin{array}{l}0.0000 \\
(2.50)^{* *}\end{array}$ & $\begin{array}{l}-0.0000 \\
(0.08)\end{array}$ & $\begin{array}{l}-0.0000 \\
(0.15)\end{array}$ \\
\hline $\begin{array}{l}\text { Federal government } \\
\text { employment }\end{array}$ & $\begin{array}{l}-0.0162 \\
(1.56)\end{array}$ & $\begin{array}{l}-0.0221 \\
(2.10)^{* *}\end{array}$ & $\begin{array}{l}-0.0213 \\
(0.85)\end{array}$ & $\begin{array}{l}-0.0145 \\
(0.52)\end{array}$ & $\begin{array}{l}-0.0134 \\
(1.15)\end{array}$ & $\begin{array}{l}-0.0214 \\
(1.78)^{* * *}\end{array}$ \\
\hline $\begin{array}{l}\text { State government } \\
\text { employment }\end{array}$ & $\begin{array}{l}0.0131 \\
(1.69)^{* * *}\end{array}$ & $\begin{array}{l}0.0065 \\
(0.84)\end{array}$ & $\begin{array}{l}-0.0166 \\
(1.22)\end{array}$ & $\begin{array}{l}-0.0355 \\
(2.40)^{* *}\end{array}$ & $\begin{array}{l}0.0247 \\
(2.74)^{*}\end{array}$ & $\begin{array}{c}0.0170 \\
(1.82)^{* * *}\end{array}$ \\
\hline $\begin{array}{l}\text { Local government } \\
\text { employment }\end{array}$ & $\begin{array}{l}-0.0047 \\
(0.55)\end{array}$ & $\begin{array}{l}-0.0001 \\
(0.02)\end{array}$ & $\begin{array}{l}-0.0147 \\
(0.78)\end{array}$ & $\begin{array}{l}-0.0095 \\
(0.45)\end{array}$ & $\begin{array}{l}0.0062 \\
(0.62)\end{array}$ & $\begin{array}{l}0.0146 \\
(1.41)\end{array}$ \\
\hline
\end{tabular}

${ }^{9}$ All RHS variables are initial values from 1970. Also, state dummies were employed in all regressions.

${ }_{10}$ All dollar values are in real 1992 dollars. 
Table A4. Growth Equation Estimates: Plains Region (continued)

\begin{tabular}{|c|c|c|c|c|c|c|}
\hline \multirow[b]{2}{*}{$\underline{\text { RHS Variables }}$} & \multicolumn{2}{|c|}{ All } & \multicolumn{2}{|c|}{ Metro } & \multicolumn{2}{|c|}{ Non-Metro } \\
\hline & $\underline{\text { OLS }}$ & $\underline{2 S L S}$ & $\underline{\text { OLS }}$ & $\underline{2 S L S}$ & $\underline{\text { OLS }}$ & $\underline{2 S L S}$ \\
\hline Self-employment & $\begin{array}{l}0.0105 \\
(1.74)^{* * *}\end{array}$ & $\begin{array}{l}0.0071 \\
(1.15)\end{array}$ & $\begin{array}{l}-0.0061 \\
(0.42)\end{array}$ & $\begin{array}{l}-0.0190 \\
(1.17)\end{array}$ & $\begin{array}{l}0.0136 \\
(2.05)^{* *}\end{array}$ & $\begin{array}{l}0.0093 \\
(1.34)\end{array}$ \\
\hline Agriculture & $\begin{array}{l}-0.0014 \\
(0.11)\end{array}$ & $\begin{array}{l}0.0012 \\
(0.10)\end{array}$ & $\begin{array}{l}0.0036 \\
(0.13)\end{array}$ & $\begin{array}{l}0.0334 \\
(1.10)\end{array}$ & $\begin{array}{l}0.0108 \\
(0.71)\end{array}$ & $\begin{array}{l}0.0159 \\
(1.00)\end{array}$ \\
\hline Communications & $\begin{array}{l}0.0111 \\
(0.56)\end{array}$ & $\begin{array}{l}0.0160 \\
(0.79)\end{array}$ & $\begin{array}{l}-0.0054 \\
(0.10)\end{array}$ & $\begin{array}{l}0.0281 \\
(0.49)\end{array}$ & $\begin{array}{l}0.0279 \\
(1.23)\end{array}$ & $\begin{array}{l}0.0361 \\
(1.52)\end{array}$ \\
\hline Construction & $\begin{array}{l}0.0020 \\
(0.14)\end{array}$ & $\begin{array}{l}-0.0034 \\
(0.22)\end{array}$ & $\begin{array}{l}0.0266 \\
(0.84)\end{array}$ & $\begin{array}{l}0.0336 \\
(0.94)\end{array}$ & $\begin{array}{l}0.0115 \\
(0.64)\end{array}$ & $\begin{array}{l}0.0062 \\
(0.33)\end{array}$ \\
\hline $\begin{array}{l}\text { Finance, insurance } \\
\text { and real estate }\end{array}$ & $\begin{array}{l}0.1084 \\
(4.68)^{*}\end{array}$ & $\begin{array}{c}0.1102 \\
(4.67)^{*}\end{array}$ & $\begin{array}{l}-0.0001 \\
(0.01)\end{array}$ & $\begin{array}{l}0.0213 \\
(0.43)\end{array}$ & $\begin{array}{c}0.1322 \\
(4.92)^{*}\end{array}$ & $\begin{array}{l}0.1348 \\
(4.81)^{*}\end{array}$ \\
\hline $\begin{array}{l}\text { Manufacturing - } \\
\text { durables }\end{array}$ & $\begin{array}{l}0.0202 \\
(1.68)^{* * * *}\end{array}$ & $\begin{array}{l}0.0153 \\
(1.25)\end{array}$ & $\begin{array}{l}0.0101 \\
(0.38)\end{array}$ & $\begin{array}{l}0.0227 \\
(0.76)\end{array}$ & $\begin{array}{l}0.0271 \\
(1.89)^{* * *}\end{array}$ & $\begin{array}{l}0.0225 \\
(1.51)\end{array}$ \\
\hline $\begin{array}{l}\text { Manufacturing - } \\
\text { nondurables }\end{array}$ & $\begin{array}{l}0.0057 \\
(0.43)\end{array}$ & $\begin{array}{l}0.0017 \\
(0.13)\end{array}$ & $\begin{array}{l}-0.0165 \\
(0.60)\end{array}$ & $\begin{array}{l}-0.0033 \\
(0.11)\end{array}$ & $\begin{array}{l}0.0188 \\
(1.19)\end{array}$ & $\begin{array}{l}0.0152 \\
(0.92)\end{array}$ \\
\hline Mining & $\begin{array}{l}0.0082 \\
(0.65)\end{array}$ & $\begin{array}{l}0.0015 \\
(0.21)\end{array}$ & $\begin{array}{l}0.0234 \\
(0.72)\end{array}$ & $\begin{array}{l}0.0241 \\
(0.65)\end{array}$ & $\begin{array}{l}0.0204 \\
(1.35)\end{array}$ & $\begin{array}{l}0.0125 \\
(0.79)\end{array}$ \\
\hline Retail & $\begin{array}{l}0.0068 \\
(0.51)\end{array}$ & $\begin{array}{l}0.0033 \\
(0.25)\end{array}$ & $\begin{array}{l}-0.0344 \\
(1.28)\end{array}$ & $\begin{array}{l}-0.0424 \\
(1.91)^{* * *}\end{array}$ & $\begin{array}{l}0.0230 \\
(1.42)\end{array}$ & $\begin{array}{l}0.0208 \\
(1.24)\end{array}$ \\
\hline $\begin{array}{l}\text { Business and repair } \\
\text { services }\end{array}$ & $\begin{array}{l}-0.0279 \\
(1.28)\end{array}$ & $\begin{array}{l}-0.0293 \\
(1.32)\end{array}$ & $\begin{array}{l}0.1690 \\
(2.99)^{*}\end{array}$ & $\begin{array}{l}0.1219 \\
(1.94)^{* * *}\end{array}$ & $\begin{array}{l}-0.0222 \\
(0.92)\end{array}$ & $\begin{array}{l}-0.0216 \\
(0.86)\end{array}$ \\
\hline Educational services & $\begin{array}{l}0.0051 \\
(0.29)\end{array}$ & $\begin{array}{l}-0.0003 \\
(0.02)\end{array}$ & $\begin{array}{l}-0.0064 \\
(0.13)\end{array}$ & $\begin{array}{l}-0.0915 \\
(1.75)^{* * *}\end{array}$ & $\begin{array}{l}0.0076 \\
(0.39)\end{array}$ & $\begin{array}{l}0.0022 \\
(0.11)\end{array}$ \\
\hline $\begin{array}{l}\text { Professional related } \\
\text { services }\end{array}$ & $\begin{array}{l}-0.0019 \\
(0.10)\end{array}$ & $\begin{array}{l}-0.0071 \\
(0.36)\end{array}$ & $\begin{array}{l}0.0032 \\
(0.06)\end{array}$ & $\begin{array}{l}0.0775 \\
(1.44)\end{array}$ & $\begin{array}{l}0.0038 \\
(0.17)\end{array}$ & $\begin{array}{l}-0.0060 \\
(0.25)\end{array}$ \\
\hline Health services & $\begin{array}{l}0.0158 \\
(0.88)\end{array}$ & $\begin{array}{l}0.0225 \\
(1.23)\end{array}$ & $\begin{array}{l}0.0264 \\
(0.54)\end{array}$ & $\begin{array}{l}-0.0447 \\
(0.84)\end{array}$ & $\begin{array}{l}0.0174 \\
(0.87)\end{array}$ & $\begin{array}{l}0.0305 \\
(1.84)^{* * *}\end{array}$ \\
\hline Personal services & $\begin{array}{l}0.0628 \\
(3.63)^{*}\end{array}$ & $\begin{array}{r}0.0609 \\
(3.45)^{*}\end{array}$ & $\begin{array}{l}0.0347 \\
(0.82)\end{array}$ & $\begin{array}{l}0.0846 \\
(1.83)^{* * *}\end{array}$ & $\begin{array}{l}0.0884 \\
(4.39)^{*}\end{array}$ & $\begin{array}{l}0.0868 \\
(4.13)^{*}\end{array}$ \\
\hline $\begin{array}{l}\text { Entertainment and } \\
\text { recreational services }\end{array}$ & $\begin{array}{l}0.1636 \\
(4.31)^{*}\end{array}$ & $\begin{array}{l}0.1611 \\
(4.16)^{*}\end{array}$ & $\begin{array}{l}0.1402 \\
(1.78)^{* * *}\end{array}$ & $\begin{array}{l}0.1940 \\
(2.21)^{* *}\end{array}$ & $\begin{array}{l}0.1830 \\
(4.16)^{*}\end{array}$ & $\begin{array}{l}0.1756 \\
(3.83)^{*}\end{array}$ \\
\hline Transportation & $\begin{array}{l}0.0202 \\
(1.25)\end{array}$ & $\begin{array}{l}0.0099 \\
(0.61)\end{array}$ & $\begin{array}{l}0.0173 \\
(0.55)\end{array}$ & $\begin{array}{l}0.0285 \\
(0.80)\end{array}$ & $\begin{array}{l}0.0242 \\
(1.26)\end{array}$ & $\begin{array}{l}0.0111 \\
(0.56)\end{array}$ \\
\hline Wholesale trade & $\begin{array}{l}0.0635 \\
(3.17)^{*}\end{array}$ & $\begin{array}{r}0.0639 \\
(3.12)^{*}\end{array}$ & $\begin{array}{l}-0.0326 \\
(0.73)\end{array}$ & $\begin{array}{l}0.0173 \\
(0.35)\end{array}$ & $\begin{array}{l}0.0657 \\
(2.85)^{*}\end{array}$ & $\begin{array}{l}0.0673 \\
(2.80)^{*}\end{array}$ \\
\hline Poverty & $\begin{array}{l}-0.0256 \\
(4.59)^{*}\end{array}$ & $\begin{array}{l}-0.0389 \\
(7.51)^{*}\end{array}$ & $\begin{array}{l}0.0171 \\
(1.19)\end{array}$ & $\begin{array}{l}-0.0253 \\
(1.91)^{* * *}\end{array}$ & $\begin{array}{l}-0.0283 \\
(4.58)^{*}\end{array}$ & $\begin{array}{l}-0.0464 \\
(7.81)^{*}\end{array}$ \\
\hline Metro area, 1970 & $\begin{array}{l}0.0012 \\
(1.00)\end{array}$ & $\begin{array}{l}0.0011 \\
(0.82)\end{array}$ & $\begin{array}{l}-0.0004 \\
(0.30)\end{array}$ & $\begin{array}{l}-0.0006 \\
(0.40)\end{array}$ & $\begin{array}{l}-0.0021 \\
(0.96)\end{array}$ & $\begin{array}{l}-0.0022 \\
(0.97)\end{array}$ \\
\hline \# Observations & 832 & 832 & 143 & 143 & 689 & 689 \\
\hline
\end{tabular}


Table A5. Growth Equation Estimates: Southern Region

\begin{tabular}{|c|c|c|c|c|c|c|}
\hline \multirow[b]{2}{*}{ RHS Variables $^{11}$} & \multicolumn{2}{|c|}{ All } & \multicolumn{2}{|c|}{ Metro } & \multicolumn{2}{|c|}{ Non-Metro } \\
\hline & OLS & $\underline{2 S L S}$ & $\underline{\text { OLS }}$ & $\underline{2 S L S}$ & $\underline{\text { OLS }}$ & $\underline{2 S L S}$ \\
\hline Constant & $\begin{array}{l}0.1494 \\
(5.30)^{*}\end{array}$ & $\begin{array}{c}0.3787 \\
(14.35)^{*}\end{array}$ & $\begin{array}{l}0.2081 \\
(2.74)^{*}\end{array}$ & $\begin{array}{r}0.4383 \\
(6.51)^{*}\end{array}$ & $\begin{array}{l}0.1531 \\
(5.11)^{*}\end{array}$ & $\begin{array}{c}0.3653 \\
(12.64)^{*}\end{array}$ \\
\hline $\begin{array}{l}\text { Log } 1970 \text { per capita } \\
\text { income }^{12}\end{array}$ & $\begin{array}{l}-0.0164 \\
(11.40)^{*}\end{array}$ & $\begin{array}{l}-0.0381 \\
(34.69)^{*}\end{array}$ & $\begin{array}{l}-0.0115 \\
(4.51)^{*}\end{array}$ & $\begin{array}{l}-0.0344 \\
(24.15)^{*}\end{array}$ & $\begin{array}{l}-0.0161 \\
(9.97)^{*}\end{array}$ & $\begin{array}{l}-0.0382 \\
(28.45)^{*}\end{array}$ \\
\hline Land area & $\begin{array}{l}0.0000 \\
(0.28)\end{array}$ & $\begin{array}{l}0.0000 \\
(0.23)\end{array}$ & $\begin{array}{l}-0.0000 \\
(0.21)\end{array}$ & $\begin{array}{l}0.0000 \\
(0.16)\end{array}$ & $\begin{array}{l}0.0000 \\
(0.69)\end{array}$ & $\begin{array}{l}-0.0000 \\
(0.60)\end{array}$ \\
\hline Water area & $\begin{array}{l}0.0000 \\
(1.21)\end{array}$ & $\begin{array}{l}0.0000 \\
(0.73)\end{array}$ & $\begin{array}{l}0.0000 \\
(1.05)\end{array}$ & $\begin{array}{l}0.0000 \\
(1.07)\end{array}$ & $\begin{array}{l}0.0000 \\
(0.15)\end{array}$ & $\begin{array}{l}-0.0000 \\
(0.02)\end{array}$ \\
\hline Age: $5-13$ years & $\begin{array}{l}0.0519 \\
(1.59)\end{array}$ & $\begin{array}{l}0.0478 \\
(1.32)\end{array}$ & $\begin{array}{l}-0.0720 \\
(0.79)\end{array}$ & $\begin{array}{l}-0.1093 \\
(1.12)\end{array}$ & $\begin{array}{c}0.0556 \\
(1.66)^{* * *}\end{array}$ & $\begin{array}{l}0.0627 \\
(1.67)^{* * *}\end{array}$ \\
\hline Age: $14-17$ years & $\begin{array}{l}-0.0258 \\
(0.91)\end{array}$ & $\begin{array}{l}-0.0719 \\
(2.29)^{* *}\end{array}$ & $\begin{array}{l}-0.1325 \\
(1.87)^{* * *}\end{array}$ & $\begin{array}{l}-0.1405 \\
(1.85)^{* * *}\end{array}$ & $\begin{array}{l}-0.0146 \\
(0.48)\end{array}$ & $\begin{array}{l}-0.0652 \\
(1.90)^{* * *}\end{array}$ \\
\hline Age: $18-64$ years & $\begin{array}{l}0.0114 \\
(0.50)\end{array}$ & $\begin{array}{l}-0.0158 \\
(0.62)\end{array}$ & $\begin{array}{l}-0.0548 \\
(0.87)\end{array}$ & $\begin{array}{l}-0.1044 \\
(1.57)\end{array}$ & $\begin{array}{l}0.0042 \\
(0.17)\end{array}$ & $\begin{array}{l}-0.0041 \\
(0.15)\end{array}$ \\
\hline Age: $65+$ & $\begin{array}{l}0.0316 \\
(0.63)\end{array}$ & $\begin{array}{l}-0.0142 \\
(0.60)\end{array}$ & $\begin{array}{l}-0.0831 \\
(1.39)\end{array}$ & $\begin{array}{l}-0.1174 \\
(1.85)^{* * *}\end{array}$ & $\begin{array}{l}0.0333 \\
(1.48)\end{array}$ & $\begin{array}{l}0.0133 \\
(0.53)\end{array}$ \\
\hline Blacks & $\begin{array}{l}-0.0033 \\
(1.98)^{* *}\end{array}$ & $\begin{array}{l}-0.0010 \\
(0.54)\end{array}$ & $\begin{array}{l}0.0028 \\
(0.56)\end{array}$ & $\begin{array}{l}0.0003 \\
(0.06)\end{array}$ & $\begin{array}{l}-0.0069 \\
(3.70)^{*}\end{array}$ & $\begin{array}{l}-0.0030 \\
(1.45)\end{array}$ \\
\hline Hispanic & $\begin{array}{l}0.0012 \\
(0.07)\end{array}$ & $\begin{array}{l}0.0096 \\
(0.45)\end{array}$ & $\begin{array}{l}-0.0520 \\
(1.76)^{* * *}\end{array}$ & $\begin{array}{l}-0.0411 \\
(1.30)\end{array}$ & $\begin{array}{l}-0.0291 \\
(0.62)\end{array}$ & $\begin{array}{l}-0.0562 \\
(1.06)\end{array}$ \\
\hline Education: $9-11$ years & $\begin{array}{l}0.0070 \\
(1.31)\end{array}$ & $\begin{array}{l}0.0170 \\
(2.89)^{*}\end{array}$ & $\begin{array}{l}0.0023 \\
(0.16)\end{array}$ & $\begin{array}{l}0.0105 \\
(0.65)\end{array}$ & $\begin{array}{l}0.0112 \\
(1.95)^{* * *}\end{array}$ & $\begin{array}{l}0.0205 \\
(3.21)^{*}\end{array}$ \\
\hline Education: H.S. diploma & $\begin{array}{l}0.0053 \\
(1.04)\end{array}$ & $\begin{array}{l}0.0106 \\
(1.85)^{* * *}\end{array}$ & $\begin{array}{l}0.0125 \\
(0.87)\end{array}$ & $\begin{array}{l}0.0111 \\
(0.72)\end{array}$ & $\begin{array}{l}0.0047 \\
(0.86)\end{array}$ & $\begin{array}{l}0.0125 \\
(2.05)^{* *}\end{array}$ \\
\hline Education: Some college & $\begin{array}{l}0.0366 \\
(2.74)^{*}\end{array}$ & $\begin{array}{l}0.0377 \\
(2.54)^{* *}\end{array}$ & $\begin{array}{l}0.0042 \\
(0.12)\end{array}$ & $\begin{array}{l}0.0037 \\
(0.10)\end{array}$ & $\begin{array}{l}0.0458 \\
(3.17)^{*}\end{array}$ & $\begin{array}{l}0.0473 \\
(2.91)^{*}\end{array}$ \\
\hline Education: Bachelor + & $\begin{array}{r}0.0449 \\
(3.84)^{*}\end{array}$ & $\begin{array}{r}0.0862 \\
(6.82)^{*}\end{array}$ & $\begin{array}{l}0.0508 \\
(1.88)^{* * *}\end{array}$ & $\begin{array}{l}0.0906 \\
(3.25)^{*}\end{array}$ & $\begin{array}{l}0.0496 \\
(3.33)^{*}\end{array}$ & $\begin{array}{r}0.0932 \\
(5.69)^{*}\end{array}$ \\
\hline $\begin{array}{l}\text { Education: Public } \\
\text { elementary }\end{array}$ & $\begin{array}{l}-0.0000 \\
(1.48)\end{array}$ & $\begin{array}{l}-0.0000 \\
(1.94)^{* * *}\end{array}$ & $\begin{array}{l}-0.0000 \\
(1.29)\end{array}$ & $\begin{array}{l}-0.0000 \\
(1.45)\end{array}$ & $\begin{array}{l}0.0000 \\
(0.50)\end{array}$ & $\begin{array}{l}0.0000 \\
(0.39)\end{array}$ \\
\hline Education: Public nursery & $\begin{array}{l}0.0000 \\
(0.36)\end{array}$ & $\begin{array}{l}0.0000 \\
(0.16)\end{array}$ & $\begin{array}{l}0.0000 \\
(0.61)\end{array}$ & $\begin{array}{l}0.0000 \\
(0.60)\end{array}$ & $\begin{array}{l}-0.0000 \\
(0.54)\end{array}$ & $\begin{array}{l}-0.0000 \\
(0.22)\end{array}$ \\
\hline $\begin{array}{l}\text { Education: Private } \\
\text { elementary }\end{array}$ & $\begin{array}{l}0.0000 \\
(0.53)\end{array}$ & $\begin{array}{l}0.0000 \\
(0.27)\end{array}$ & $\begin{array}{l}0.0000 \\
(0.27)\end{array}$ & $\begin{array}{l}0.0000 \\
(0.16)\end{array}$ & $\begin{array}{l}0.0000 \\
(1.72)^{* * *}\end{array}$ & $\begin{array}{l}0.0000 \\
(1.41)\end{array}$ \\
\hline Education: Private nursery & $\begin{array}{l}-0.0000 \\
(1.66)^{* * *}\end{array}$ & $\begin{array}{l}-0.0000 \\
(1.69)^{* * *}\end{array}$ & $\begin{array}{l}-0.0000 \\
(1.46)\end{array}$ & $\begin{array}{l}-0.0000 \\
(1.13)\end{array}$ & $\begin{array}{l}0.0000 \\
(0.49)\end{array}$ & $\begin{array}{l}-0.0000 \\
(0.23)\end{array}$ \\
\hline Housing & $\begin{array}{l}0.0000 \\
(1.88)^{* * *}\end{array}$ & $\begin{array}{l}0.0000 \\
(2.77)^{*}\end{array}$ & $\begin{array}{l}0.0000 \\
(1.01)\end{array}$ & $\begin{array}{l}0.0000 \\
(1.22)\end{array}$ & $\begin{array}{l}-0.0000 \\
(0.41)\end{array}$ & $\begin{array}{l}0.0000 \\
(0.27)\end{array}$ \\
\hline $\begin{array}{l}\text { Federal government } \\
\text { employment }\end{array}$ & $\begin{array}{l}-0.0153 \\
(1.88)^{* * *}\end{array}$ & $\begin{array}{l}-0.0242 \\
(2.68)^{*}\end{array}$ & $\begin{array}{l}-0.0188 \\
(0.93)\end{array}$ & $\begin{array}{l}-0.0321 \\
(1.94)^{* * *}\end{array}$ & $\begin{array}{l}-0.0153 \\
(1.66)^{* * *}\end{array}$ & $\begin{array}{l}-0.0172 \\
(1.65)^{* * *}\end{array}$ \\
\hline $\begin{array}{l}\text { State government } \\
\text { employment }\end{array}$ & $\begin{array}{l}0.0034 \\
(0.52)\end{array}$ & $\begin{array}{l}-0.0016 \\
(1.58)\end{array}$ & $\begin{array}{l}0.0073 \\
(0.45)\end{array}$ & $\begin{array}{l}-0.0119 \\
(0.70)\end{array}$ & $\begin{array}{l}0.0009 \\
(0.12)\end{array}$ & $\begin{array}{l}-0.0121 \\
(1.44)\end{array}$ \\
\hline $\begin{array}{l}\text { Local government } \\
\text { employment }\end{array}$ & $\begin{array}{l}-0.0011 \\
(0.11)\end{array}$ & $\begin{array}{l}-0.0072 \\
(0.65)\end{array}$ & $\begin{array}{l}-0.0141 \\
(0.45)\end{array}$ & $\begin{array}{l}-0.0113 \\
(0.34)\end{array}$ & $\begin{array}{l}0.0043 \\
(0.42)\end{array}$ & $\begin{array}{l}-0.0004 \\
(0.04)\end{array}$ \\
\hline
\end{tabular}

${ }_{11}$ All RHS variables are initial values from 1970. Also, state dummies were employed in all regressions.

12 All dollar values are in real 1992 dollars. 
Table A5. Growth Equation Estimates: Southern Region (continued)

\begin{tabular}{|c|c|c|c|c|c|c|}
\hline \multirow[b]{2}{*}{$\underline{\text { RHS Variables }}$} & \multicolumn{2}{|c|}{ All } & \multicolumn{2}{|c|}{ Metro } & \multicolumn{2}{|c|}{ Non-Metro } \\
\hline & $\underline{\text { OLS }}$ & $\underline{2 S L S}$ & $\underline{\text { OLS }}$ & $\underline{2 S L S}$ & $\underline{\text { OLS }}$ & $\underline{2 S L S}$ \\
\hline Self-employment & $\begin{array}{l}-0.0028 \\
(0.44)\end{array}$ & $\begin{array}{l}-0.0079 \\
(1.12)\end{array}$ & $\begin{array}{l}0.0235 \\
(1.12)\end{array}$ & $\begin{array}{l}0.0145 \\
(0.65)\end{array}$ & $\begin{array}{l}-0.0035 \\
(0.53)\end{array}$ & $\begin{array}{l}-0.0096 \\
(1.30)\end{array}$ \\
\hline Agriculture & $\begin{array}{l}-0.0049 \\
(0.46)\end{array}$ & $\begin{array}{l}-0.0054 \\
(0.45)\end{array}$ & $\begin{array}{l}0.0094 \\
(0.38)\end{array}$ & $\begin{array}{l}0.0005 \\
(0.02)\end{array}$ & $\begin{array}{l}-0.0126 \\
(1.02)\end{array}$ & $\begin{array}{l}-0.0034 \\
(0.24)\end{array}$ \\
\hline Communications & $\begin{array}{l}-0.0464 \\
(3.25)^{*}\end{array}$ & $\begin{array}{l}-0.0373 \\
(2.36)^{* *}\end{array}$ & $\begin{array}{l}-0.0063 \\
(0.15)\end{array}$ & $\begin{array}{l}-0.0324 \\
(0.74)\end{array}$ & $\begin{array}{l}-0.0516 \\
(3.46)^{*}\end{array}$ & $\begin{array}{l}-0.0335 \\
(2.00)^{*}\end{array}$ \\
\hline Construction & $\begin{array}{l}0.0238 \\
(2.14)^{* *}\end{array}$ & $\begin{array}{l}0.0099 \\
(0.80)\end{array}$ & $\begin{array}{l}0.0306 \\
(1.22)\end{array}$ & $\begin{array}{l}0.0125 \\
(0.47)\end{array}$ & $\begin{array}{l}0.0126 \\
(0.97)\end{array}$ & $\begin{array}{l}0.0061 \\
(0.41)\end{array}$ \\
\hline $\begin{array}{l}\text { Finance, insurance } \\
\text { and real estate }\end{array}$ & $\begin{array}{l}0.0263 \\
(1.18)\end{array}$ & $\begin{array}{l}0.0481 \\
(1.94)^{* * *}\end{array}$ & $\begin{array}{l}0.0357 \\
(0.66)\end{array}$ & $\begin{array}{l}0.0608 \\
(1.06)\end{array}$ & $\begin{array}{l}-0.0105 \\
(0.43)\end{array}$ & $\begin{array}{l}0.0032 \\
(0.12)\end{array}$ \\
\hline $\begin{array}{l}\text { Manufacturing - } \\
\text { durables }\end{array}$ & $\begin{array}{l}-0.0034 \\
(0.34)\end{array}$ & $\begin{array}{l}-0.0155 \\
(1.39)\end{array}$ & $\begin{array}{l}0.0102 \\
(0.46)\end{array}$ & $\begin{array}{l}-0.0119 \\
(0.50)\end{array}$ & $\begin{array}{l}-0.0114 \\
(0.99)\end{array}$ & $\begin{array}{l}-0.0148 \\
(1.14)\end{array}$ \\
\hline $\begin{array}{l}\text { Manufacturing - } \\
\text { nondurables }\end{array}$ & $\begin{array}{l}-0.0110 \\
(1.10)\end{array}$ & $\begin{array}{l}-0.0231 \\
(2.08)^{* *}\end{array}$ & $\begin{array}{l}0.0021 \\
(0.09)\end{array}$ & $\begin{array}{l}-0.0173 \\
(0.72)\end{array}$ & $\begin{array}{l}-0.0181 \\
(1.57)\end{array}$ & $\begin{array}{l}-0.0227 \\
(1.75)^{* *}\end{array}$ \\
\hline Mining & $\begin{array}{l}-0.0139 \\
(1.29)\end{array}$ & $\begin{array}{l}-0.0183 \\
(1.53)\end{array}$ & $\begin{array}{l}-0.0121 \\
(0.40)\end{array}$ & $\begin{array}{l}-0.0483 \\
(1.53)\end{array}$ & $\begin{array}{l}-0.0236 \\
(1.95)^{* * *}\end{array}$ & $\begin{array}{l}-0.0172 \\
(1.26)\end{array}$ \\
\hline Retail & $\begin{array}{l}-0.0269 \\
(2.21)^{* *}\end{array}$ & $\begin{array}{l}-0.0375 \\
(2.77)^{*}\end{array}$ & $\begin{array}{l}-0.0028 \\
(0.10)\end{array}$ & $\begin{array}{l}-0.0263 \\
(0.91)\end{array}$ & $\begin{array}{l}-0.0293 \\
(2.08)^{* *}\end{array}$ & $\begin{array}{l}-0.0293 \\
(1.85)^{* * *}\end{array}$ \\
\hline $\begin{array}{l}\text { Business and repair } \\
\text { services }\end{array}$ & $\begin{array}{l}0.0321 \\
(1.51)\end{array}$ & $\begin{array}{l}0.0307 \\
(1.30)\end{array}$ & $\begin{array}{l}0.0524 \\
(0.87)\end{array}$ & $\begin{array}{l}0.0434 \\
(0.67)\end{array}$ & $\begin{array}{l}0.0223 \\
(0.99)\end{array}$ & $\begin{array}{l}0.0269 \\
(1.07)\end{array}$ \\
\hline Educational services & $\begin{array}{l}0.0047 \\
(0.22)\end{array}$ & $\begin{array}{l}-0.0136 \\
(0.56)\end{array}$ & $\begin{array}{l}-0.0986 \\
(1.74)^{* * *}\end{array}$ & $\begin{array}{l}-0.0601 \\
(1.00)\end{array}$ & $\begin{array}{c}0.0494 \\
(2.10)^{* *}\end{array}$ & $\begin{array}{l}0.0103 \\
(0.39)\end{array}$ \\
\hline $\begin{array}{l}\text { Professional related } \\
\text { services }\end{array}$ & $\begin{array}{l}-0.0251 \\
(1.13)\end{array}$ & $\begin{array}{l}-0.0324 \\
(1.31)\end{array}$ & $\begin{array}{l}0.0564 \\
(0.98)\end{array}$ & $\begin{array}{l}-0.0039 \\
(0.07)\end{array}$ & $\begin{array}{l}-0.0665 \\
(2.72)^{*}\end{array}$ & $\begin{array}{l}-0.0523 \\
(1.90)^{* * *}\end{array}$ \\
\hline Health services & $\begin{array}{l}0.0202 \\
(0.91)\end{array}$ & $\begin{array}{l}0.0173 \\
(0.70)\end{array}$ & $\begin{array}{l}-0.0504 \\
(0.85)\end{array}$ & $\begin{array}{l}-0.0002 \\
(0.01)\end{array}$ & $\begin{array}{c}0.0529 \\
(2.21)^{* *}\end{array}$ & $\begin{array}{l}0.0335 \\
(1.25)\end{array}$ \\
\hline Personal services & $\begin{array}{l}0.0204 \\
(1.57)\end{array}$ & $\begin{array}{l}0.0209 \\
(1.45)\end{array}$ & $\begin{array}{c}0.0639 \\
(1.73)^{* * *}\end{array}$ & $\begin{array}{c}0.0775 \\
(1.97)^{* *}\end{array}$ & $\begin{array}{l}0.0007 \\
(0.51)\end{array}$ & $\begin{array}{l}0.0123 \\
(0.76)\end{array}$ \\
\hline $\begin{array}{l}\text { Entertainment and } \\
\text { recreational services }\end{array}$ & $\begin{array}{l}0.1038 \\
(2.53)^{* *}\end{array}$ & $\begin{array}{l}0.1148 \\
(2.52)^{* *}\end{array}$ & $\begin{array}{l}0.1717 \\
(1.57)\end{array}$ & $\begin{array}{l}0.1125 \\
(1.98)^{* *}\end{array}$ & $\begin{array}{l}0.0759 \\
(1.74)^{* * *}\end{array}$ & $\begin{array}{l}0.1058 \\
(2.16)^{* *}\end{array}$ \\
\hline Transportation & $\begin{array}{l}-0.0171 \\
(1.30)\end{array}$ & $\begin{array}{l}-0.0334 \\
(2.29)^{* *}\end{array}$ & $\begin{array}{l}0.0106 \\
(0.32)\end{array}$ & $\begin{array}{l}0.0027 \\
(0.08)\end{array}$ & $\begin{array}{l}-0.0306 \\
(2.10)^{* *}\end{array}$ & $\begin{array}{l}-0.0413 \\
(2.52)^{* *}\end{array}$ \\
\hline Wholesale trade & $\begin{array}{l}0.0475 \\
(2.83)^{*}\end{array}$ & $\begin{array}{l}0.0372 \\
(2.00)^{* * *}\end{array}$ & $\begin{array}{l}0.0803 \\
(1.85)^{* * *}\end{array}$ & $\begin{array}{l}0.0624 \\
(1.83)^{* * *}\end{array}$ & $\begin{array}{l}0.0338 \\
(1.85)^{* * *}\end{array}$ & $\begin{array}{l}0.0249 \\
(1.21)\end{array}$ \\
\hline Poverty & $\begin{array}{l}-0.0142 \\
(3.39)^{*}\end{array}$ & $\begin{array}{l}-0.0456 \\
(11.23)^{*}\end{array}$ & $\begin{array}{l}-0.0179 \\
(1.47)\end{array}$ & $\begin{array}{l}-0.0476 \\
(4.08)^{*}\end{array}$ & $\begin{array}{l}-0.0127 \\
(2.91)^{*}\end{array}$ & $\begin{array}{l}-0.0403 \\
(9.81)^{*}\end{array}$ \\
\hline Metro area, 1970 & $\begin{array}{l}-0.0005 \\
(0.85)\end{array}$ & $\begin{array}{l}-0.0007 \\
(0.96)\end{array}$ & $\begin{array}{l}-0.0012 \\
(0.21)\end{array}$ & $\begin{array}{l}-0.0014 \\
(1.11)\end{array}$ & $\begin{array}{l}-0.0016 \\
(1.69)^{* * *}\end{array}$ & $\begin{array}{l}-0.0015 \\
(1.31)\end{array}$ \\
\hline \# Observations & 1009 & 1009 & 252 & 252 & 757 & 757 \\
\hline
\end{tabular}


Table A6. Growth Equation Estimates: Western Region

\begin{tabular}{|c|c|c|c|c|c|c|}
\hline \multirow[b]{2}{*}{$\underline{\text { RHS Variables }}^{13}$} & \multicolumn{2}{|c|}{ All } & \multicolumn{2}{|c|}{ Metro } & \multicolumn{2}{|c|}{ Non-Metro } \\
\hline & $\underline{\text { OLS }}$ & $\underline{2 S L S}$ & $\underline{\text { OLS }}$ & $\underline{2 S L S}$ & $\underline{\text { OLS }}$ & $\underline{2 S L S}$ \\
\hline Constant & $\begin{array}{l}0.1940 \\
(4.81)^{*}\end{array}$ & $\begin{array}{l}0.3465 \\
(8.98)^{*}\end{array}$ & $\begin{array}{l}0.0187 \\
(0.26)\end{array}$ & $\begin{array}{r}0.3617 \\
(4.87)^{*}\end{array}$ & $\begin{array}{l}0.1992 \\
(3.73)^{*}\end{array}$ & $\begin{array}{l}0.3104 \\
(5.99)^{*}\end{array}$ \\
\hline $\begin{array}{l}\text { Log } 1970 \text { per capita } \\
\text { income }^{14}\end{array}$ & $\begin{array}{l}-0.0205 \\
(11.34)^{*}\end{array}$ & $\begin{array}{l}-0.0358 \\
(17.84)^{*}\end{array}$ & $\begin{array}{l}-0.0096 \\
(3.00)^{*}\end{array}$ & $\begin{array}{l}-0.0391 \\
(20.52)^{*}\end{array}$ & $\begin{array}{l}-0.0225 \\
(9.23)^{*}\end{array}$ & $\begin{array}{l}-0.0356 \\
(15.93)^{*}\end{array}$ \\
\hline Land area & $\begin{array}{l}-0.0000 \\
(1.99)^{* *}\end{array}$ & $\begin{array}{l}-0.0000 \\
(2.20)^{* *}\end{array}$ & $\begin{array}{l}-0.0000 \\
(2.23)^{* * *}\end{array}$ & $\begin{array}{l}-0.0000 \\
(1.39)\end{array}$ & $\begin{array}{l}0.0000 \\
(0.02)\end{array}$ & $\begin{array}{l}-0.0000 \\
(0.80)\end{array}$ \\
\hline Water area & $\begin{array}{l}0.0000 \\
(1.79)^{* * *}\end{array}$ & $\begin{array}{l}0.0000 \\
(1.71)^{* * *}\end{array}$ & $\begin{array}{l}0.0000 \\
(0.76)\end{array}$ & $\begin{array}{l}0.0000 \\
(0.20)\end{array}$ & $\begin{array}{l}0.0000 \\
(0.81)\end{array}$ & $\begin{array}{l}0.0000 \\
(0.85)\end{array}$ \\
\hline Age: $5-13$ years & $\begin{array}{l}0.0251 \\
(0.54)\end{array}$ & $\begin{array}{l}0.0294 \\
(0.59)\end{array}$ & $\begin{array}{l}0.0933 \\
(1.11)\end{array}$ & $\begin{array}{l}0.0353 \\
(0.35)\end{array}$ & $\begin{array}{l}0.0239 \\
(0.39)\end{array}$ & $\begin{array}{l}0.0469 \\
(0.73)\end{array}$ \\
\hline Age: $14-17$ years & $\begin{array}{l}-0.0014 \\
(0.04)\end{array}$ & $\begin{array}{l}0.0024 \\
(0.05)\end{array}$ & $\begin{array}{l}0.1103 \\
(1.65)^{* * *}\end{array}$ & $\begin{array}{l}0.0441 \\
(1.75)^{* * *}\end{array}$ & $\begin{array}{l}-0.0415 \\
(0.68)\end{array}$ & $\begin{array}{l}-0.0067 \\
(0.11)\end{array}$ \\
\hline Age: $18-64$ years & $\begin{array}{l}0.0228 \\
(0.64)\end{array}$ & $\begin{array}{l}0.0176 \\
(0.46)\end{array}$ & $\begin{array}{l}0.0621 \\
(1.01)\end{array}$ & $\begin{array}{l}0.0101 \\
(0.14)\end{array}$ & $\begin{array}{l}0.0331 \\
(0.68)\end{array}$ & $\begin{array}{l}0.0437 \\
(0.85)\end{array}$ \\
\hline Age: $65+$ & $\begin{array}{l}0.0136 \\
(0.44)\end{array}$ & $\begin{array}{l}-0.0029 \\
(0.09)\end{array}$ & $\begin{array}{l}0.0714 \\
(1.32)\end{array}$ & $\begin{array}{l}0.0001 \\
(0.02)\end{array}$ & $\begin{array}{l}0.0144 \\
(0.35)\end{array}$ & $\begin{array}{l}0.0093 \\
(0.21)\end{array}$ \\
\hline Blacks & $\begin{array}{l}0.0047 \\
(1.06)\end{array}$ & $\begin{array}{l}0.0054 \\
(1.13)\end{array}$ & $\begin{array}{l}0.0045 \\
(0.73)\end{array}$ & $\begin{array}{l}0.0096 \\
(1.28)\end{array}$ & $\begin{array}{l}0.0071 \\
(1.08)\end{array}$ & $\begin{array}{l}0.0067 \\
(0.95)\end{array}$ \\
\hline Hispanic & $\begin{array}{l}-0.0057 \\
(2.03)^{* *}\end{array}$ & $\begin{array}{l}-0.0076 \\
(2.54)^{* *}\end{array}$ & $\begin{array}{l}-0.0019 \\
(0.38)\end{array}$ & $\begin{array}{l}0.0088 \\
(0.14)\end{array}$ & $\begin{array}{l}-0.0051 \\
(1.31)\end{array}$ & $\begin{array}{l}-0.0068 \\
(1.67)^{* * *}\end{array}$ \\
\hline Education: 9-11 years & $\begin{array}{l}-0.0296 \\
(3.43)^{*}\end{array}$ & $\begin{array}{l}-0.0426 \\
(4.68)^{*}\end{array}$ & $\begin{array}{l}-0.0386 \\
(2.51)^{* *}\end{array}$ & $\begin{array}{l}-0.0385 \\
(2.10)^{* *}\end{array}$ & $\begin{array}{l}-0.0207 \\
(1.85)^{* * *}\end{array}$ & $\begin{array}{l}-0.0323 \\
(2.79)^{*}\end{array}$ \\
\hline Education: H.S. diploma & $\begin{array}{l}0.0108 \\
(1.28)\end{array}$ & $\begin{array}{c}0.0203 \\
(2.26)^{* *}\end{array}$ & $\begin{array}{l}-0.0068 \\
(0.50)\end{array}$ & $\begin{array}{l}0.0025 \\
(0.16)\end{array}$ & $\begin{array}{l}0.0305 \\
(2.63)^{*}\end{array}$ & $\begin{array}{l}0.0393 \\
(3.24)^{*}\end{array}$ \\
\hline Education: Some college & $\begin{array}{l}0.0118 \\
(0.83)\end{array}$ & $\begin{array}{l}0.0197 \\
(1.30)\end{array}$ & $\begin{array}{l}-0.0286 \\
(1.19)\end{array}$ & $\begin{array}{l}0.0018 \\
(0.06)\end{array}$ & $\begin{array}{l}0.0341 \\
(1.79)^{* * *}\end{array}$ & $\begin{array}{l}0.0426 \\
(2.13)^{* *}\end{array}$ \\
\hline Education: Bachelor + & $\begin{array}{l}0.0222 \\
(1.60)\end{array}$ & $\begin{array}{l}0.0405 \\
(2.76)^{*}\end{array}$ & $\begin{array}{l}0.0330 \\
(1.43)\end{array}$ & $\begin{array}{r}0.0839 \\
(3.15)^{*}\end{array}$ & $\begin{array}{l}0.0022 \\
(0.11)\end{array}$ & $\begin{array}{l}0.0279 \\
(1.32)\end{array}$ \\
\hline $\begin{array}{l}\text { Education: Public } \\
\text { elementary }\end{array}$ & $\begin{array}{l}-0.0000 \\
(0.98)\end{array}$ & $\begin{array}{l}-0.0000 \\
(1.67)^{* * *}\end{array}$ & $\begin{array}{l}0.0000 \\
(0.16)\end{array}$ & $\begin{array}{l}-0.0000 \\
(0.88)\end{array}$ & $\begin{array}{l}-0.0000 \\
(1.20)\end{array}$ & $\begin{array}{l}-0.0000 \\
(1.65)^{* * *}\end{array}$ \\
\hline Education: Public nursery & $\begin{array}{l}0.0000 \\
(0.56)\end{array}$ & $\begin{array}{l}0.0000 \\
(0.63)\end{array}$ & $\begin{array}{l}-0.0000 \\
(0.17)\end{array}$ & $\begin{array}{l}0.0000 \\
(0.16)\end{array}$ & $\begin{array}{l}0.0000 \\
(0.05)\end{array}$ & $\begin{array}{l}0.0000 \\
(0.15)\end{array}$ \\
\hline $\begin{array}{l}\text { Education: Private } \\
\text { elementary }\end{array}$ & $\begin{array}{l}-0.0000 \\
(1.23)\end{array}$ & $\begin{array}{l}-0.0000 \\
(1.52)\end{array}$ & $\begin{array}{l}-0.0000 \\
(1.12)\end{array}$ & $\begin{array}{l}-0.0000 \\
(0.94)\end{array}$ & $\begin{array}{l}0.0000 \\
(1.33)\end{array}$ & $\begin{array}{l}0.0000 \\
(0.91)\end{array}$ \\
\hline Education: Private nursery & $\begin{array}{l}0.0000 \\
(1.85)^{* * *}\end{array}$ & $\begin{array}{l}0.0000 \\
(2.07)^{* *}\end{array}$ & $\begin{array}{l}0.0000 \\
(0.46)\end{array}$ & $\begin{array}{l}0.0000 \\
(0.97)\end{array}$ & $\begin{array}{l}0.0000 \\
(0.02)\end{array}$ & $\begin{array}{l}-0.0000 \\
(0.68)\end{array}$ \\
\hline Housing & $\begin{array}{l}0.0000 \\
(0.36)\end{array}$ & $\begin{array}{l}0.0000 \\
(0.93)\end{array}$ & $\begin{array}{l}0.0000 \\
(0.27)\end{array}$ & $\begin{array}{l}0.0000 \\
(0.65)\end{array}$ & $\begin{array}{l}0.0000 \\
(1.02)\end{array}$ & $\begin{array}{l}0.0000 \\
(1.48)\end{array}$ \\
\hline $\begin{array}{l}\text { Federal government } \\
\text { employment }\end{array}$ & $\begin{array}{l}-0.0147 \\
(1.37)\end{array}$ & $\begin{array}{l}-0.0175 \\
(1.52)\end{array}$ & $\begin{array}{l}-0.0021 \\
(0.11)\end{array}$ & $\begin{array}{l}-0.0177 \\
(0.80)\end{array}$ & $\begin{array}{l}-0.0083 \\
(0.58)\end{array}$ & $\begin{array}{l}-0.0087 \\
(0.58)\end{array}$ \\
\hline $\begin{array}{l}\text { State government } \\
\text { employment }\end{array}$ & $\begin{array}{l}-0.0009 \\
(0.10)\end{array}$ & $\begin{array}{l}-0.0152 \\
(1.49)\end{array}$ & $\begin{array}{l}-0.0054 \\
(0.41)\end{array}$ & $\begin{array}{l}-0.0228 \\
(1.65)^{* * *}\end{array}$ & $\begin{array}{l}0.0104 \\
(0.70)\end{array}$ & $\begin{array}{l}-0.0041 \\
(0.26)\end{array}$ \\
\hline $\begin{array}{l}\text { Local government } \\
\text { employment }\end{array}$ & $\begin{array}{l}-0.0239 \\
(2.04)^{* *}\end{array}$ & $\begin{array}{l}-0.0291 \\
(2.32)^{* *}\end{array}$ & $\begin{array}{l}-0.0155 \\
(0.83)\end{array}$ & $\begin{array}{l}-0.0438 \\
(1.99)^{* *}\end{array}$ & $\begin{array}{l}-0.0214 \\
(1.29)\end{array}$ & $\begin{array}{l}-0.0229 \\
(1.31)\end{array}$ \\
\hline
\end{tabular}

${ }_{13}$ All RHS variables are initial values from 1970. Also, state dummies were employed in all regressions.

${ }^{14}$ All dollar values are in real 1992 dollars. 
Table A6. Growth Equation Estimates: Western Region (continued)

\begin{tabular}{|c|c|c|c|c|c|c|}
\hline \multirow[b]{2}{*}{$\underline{\text { RHS Variables }}$} & \multicolumn{2}{|c|}{ All } & \multicolumn{2}{|c|}{ Metro } & \multicolumn{2}{|c|}{ Non-Metro } \\
\hline & $\underline{\text { OLS }}$ & $\underline{2 S L S}$ & $\underline{\text { OLS }}$ & $\underline{2 S L S}$ & $\underline{\text { OLS }}$ & $\underline{2 S L S}$ \\
\hline Self-employment & $\begin{array}{l}0.0054 \\
(0.64)\end{array}$ & $\begin{array}{l}0.0082 \\
(0.91)\end{array}$ & $\begin{array}{l}0.0025 \\
(0.19)\end{array}$ & $\begin{array}{l}0.0001 \\
(0.06)\end{array}$ & $\begin{array}{l}0.0051 \\
(0.44)\end{array}$ & $\begin{array}{l}0.0083 \\
(0.68)\end{array}$ \\
\hline Agriculture & $\begin{array}{l}-0.0116 \\
(0.84)\end{array}$ & $\begin{array}{l}-0.0053 \\
(0.36)\end{array}$ & $\begin{array}{l}0.0141 \\
(0.64)\end{array}$ & $\begin{array}{l}0.0304 \\
(1.17)\end{array}$ & $\begin{array}{l}-0.0046 \\
(0.25)\end{array}$ & $\begin{array}{l}0.0008 \\
(0.04)\end{array}$ \\
\hline Communications & $\begin{array}{l}-0.0473 \\
(1.89)^{* * *}\end{array}$ & $\begin{array}{l}-0.0558 \\
(2.08)^{* *}\end{array}$ & $\begin{array}{l}0.0531 \\
(1.28)\end{array}$ & $\begin{array}{l}0.0336 \\
(1.68)^{* * *}\end{array}$ & $\begin{array}{l}-0.0656 \\
(1.99)^{* *}\end{array}$ & $\begin{array}{l}-0.0760 \\
(2.196)^{*}\end{array}$ \\
\hline Construction & $\begin{array}{l}-0.0002 \\
(0.02)\end{array}$ & $\begin{array}{l}-0.0002 \\
(0.01)\end{array}$ & $\begin{array}{r}0.0665 \\
(2.62)^{*}\end{array}$ & $\begin{array}{l}0.0685 \\
(2.26)^{* *}\end{array}$ & $\begin{array}{l}-0.0113 \\
(0.54)\end{array}$ & $\begin{array}{l}-0.0091 \\
(0.42)\end{array}$ \\
\hline $\begin{array}{l}\text { Finance, insurance } \\
\text { and real estate }\end{array}$ & $\begin{array}{l}0.1037 \\
(3.37)^{*}\end{array}$ & $\begin{array}{l}0.1272 \\
(3.88)^{*}\end{array}$ & $\begin{array}{l}0.1742 \\
(3.70)^{*}\end{array}$ & $\begin{array}{l}0.1872 \\
(3.33)^{*}\end{array}$ & $\begin{array}{l}0.0567 \\
(1.28)\end{array}$ & $\begin{array}{l}0.0916 \\
(1.98)^{* * *}\end{array}$ \\
\hline $\begin{array}{l}\text { Manufacturing - } \\
\text { durables }\end{array}$ & $\begin{array}{l}0.0062 \\
(0.47)\end{array}$ & $\begin{array}{l}0.0010 \\
(0.07)\end{array}$ & $\begin{array}{l}0.0403 \\
(1.93)^{* * *}\end{array}$ & $\begin{array}{l}0.0192 \\
(1.78)^{* * *}\end{array}$ & $\begin{array}{l}0.0150 \\
(0.80)\end{array}$ & $\begin{array}{l}0.0142 \\
(0.72)\end{array}$ \\
\hline $\begin{array}{l}\text { Manufacturing - } \\
\text { nondurables }\end{array}$ & $\begin{array}{l}-0.0081 \\
(0.56)\end{array}$ & $\begin{array}{l}-0.0124 \\
(0.80)\end{array}$ & $\begin{array}{l}0.0068 \\
(0.31)\end{array}$ & $\begin{array}{l}-0.0062 \\
(0.24)\end{array}$ & $\begin{array}{l}0.0008 \\
(0.04)\end{array}$ & $\begin{array}{l}-0.0003 \\
(0.02)\end{array}$ \\
\hline Mining & $\begin{array}{l}-0.0103 \\
(0.74)\end{array}$ & $\begin{array}{l}-0.0112 \\
(0.75)\end{array}$ & $\begin{array}{l}0.0223 \\
(1.00)\end{array}$ & $\begin{array}{l}-0.0013 \\
(0.05)\end{array}$ & $\begin{array}{l}-0.0014 \\
(0.08)\end{array}$ & $\begin{array}{l}-0.0007 \\
(0.04)\end{array}$ \\
\hline Retail & $\begin{array}{l}-0.0281 \\
(1.73)^{* * * *}\end{array}$ & $\begin{array}{l}-0.0382 \\
(2.21)^{* * * *}\end{array}$ & $\begin{array}{l}-0.0221 \\
(0.83)\end{array}$ & $\begin{array}{l}-0.0406 \\
(1.72)^{* * *}\end{array}$ & $\begin{array}{l}-0.0158 \\
(0.72)\end{array}$ & $\begin{array}{l}-0.0209 \\
(0.91)\end{array}$ \\
\hline $\begin{array}{l}\text { Business and repair } \\
\text { services }\end{array}$ & $\begin{array}{l}0.0125 \\
(0.49)\end{array}$ & $\begin{array}{l}0.0161 \\
(0.59)\end{array}$ & $\begin{array}{l}-0.0061 \\
(0.15)\end{array}$ & $\begin{array}{l}-0.0149 \\
(0.31)\end{array}$ & $\begin{array}{l}0.0556 \\
(1.46)\end{array}$ & $\begin{array}{l}0.0689 \\
(1.72)^{* * *}\end{array}$ \\
\hline Educational services & $\begin{array}{l}-0.0267 \\
(1.90)^{* * *}\end{array}$ & $\begin{array}{l}-0.0405 \\
(3.03)^{*}\end{array}$ & $\begin{array}{l}0.0124 \\
(0.69)\end{array}$ & $\begin{array}{l}-0.0493 \\
(2.48)^{* *}\end{array}$ & $\begin{array}{l}0.0042 \\
(0.13)\end{array}$ & $\begin{array}{l}-0.0185 \\
(0.53)\end{array}$ \\
\hline $\begin{array}{l}\text { Professional related } \\
\text { services }\end{array}$ & $\begin{array}{l}0.0071 \\
(0.45)\end{array}$ & $\begin{array}{l}0.0158 \\
(0.93)\end{array}$ & $\begin{array}{l}0.0206 \\
(0.97)\end{array}$ & $\begin{array}{l}0.0232 \\
(0.91)\end{array}$ & $\begin{array}{l}-0.0282 \\
(0.84)\end{array}$ & $\begin{array}{l}-0.0069 \\
(0.20)\end{array}$ \\
\hline Health services & $\begin{array}{l}0.0087 \\
(0.50)\end{array}$ & $\begin{array}{l}0.0054 \\
(0.29)\end{array}$ & $\begin{array}{l}0.0187 \\
(0.82)\end{array}$ & $\begin{array}{l}0.0185 \\
(0.67)\end{array}$ & $\begin{array}{l}0.0481 \\
(1.38)\end{array}$ & $\begin{array}{l}0.0319 \\
(0.87)\end{array}$ \\
\hline Personal services & $\begin{array}{l}0.0045 \\
(0.27)\end{array}$ & $\begin{array}{l}0.0115 \\
(0.64)\end{array}$ & $\begin{array}{l}0.0302 \\
(1.20)\end{array}$ & $\begin{array}{l}0.0288 \\
(0.96)\end{array}$ & $\begin{array}{l}0.0203 \\
(0.80)\end{array}$ & $\begin{array}{l}0.0324 \\
(1.21)\end{array}$ \\
\hline $\begin{array}{l}\text { Entertainment and } \\
\text { recreational services }\end{array}$ & $\begin{array}{l}-0.0072 \\
(0.30)\end{array}$ & $\begin{array}{l}-0.0052 \\
(0.20)\end{array}$ & $\begin{array}{l}0.0295 \\
(0.68)\end{array}$ & $\begin{array}{l}0.0141 \\
(0.27)\end{array}$ & $\begin{array}{l}0.0111 \\
(0.36)\end{array}$ & $\begin{array}{l}0.0101 \\
(0.31)\end{array}$ \\
\hline Transportation & $\begin{array}{l}-0.0086 \\
(0.44)\end{array}$ & $\begin{array}{l}-0.0056 \\
(0.27)\end{array}$ & $\begin{array}{l}0.0479 \\
(1.54)\end{array}$ & $\begin{array}{l}0.0586 \\
(1.85)^{* * *}\end{array}$ & $\begin{array}{l}-0.0112 \\
(0.43)\end{array}$ & $\begin{array}{l}-0.0079 \\
(0.29)\end{array}$ \\
\hline Wholesale trade & $\begin{array}{l}0.0010 \\
(0.05)\end{array}$ & $\begin{array}{l}0.0001 \\
(0.01)\end{array}$ & $\begin{array}{l}0.0193 \\
(0.69)\end{array}$ & $\begin{array}{l}-0.0117 \\
(0.36)\end{array}$ & $\begin{array}{l}-0.0098 \\
(0.27)\end{array}$ & $\begin{array}{l}0.0128 \\
(0.33)\end{array}$ \\
\hline Poverty & $\begin{array}{l}-0.0152 \\
(2.14)^{* *}\end{array}$ & $\begin{array}{l}-0.0383 \\
(5.49)^{*}\end{array}$ & $\begin{array}{l}-0.0213 \\
(1.90)^{* * *}\end{array}$ & $\begin{array}{l}-0.0726 \\
(6.21)^{*}\end{array}$ & $\begin{array}{l}-0.0045 \\
(0.47)\end{array}$ & $\begin{array}{l}-0.0218 \\
(2.27)^{* *}\end{array}$ \\
\hline Metro area, 1970 & $\begin{array}{c}0.0024 \\
(2.52)^{* *}\end{array}$ & $\begin{array}{l}0.0023 \\
(2.25)^{* *}\end{array}$ & $\begin{array}{l}0.0005 \\
(0.48)\end{array}$ & $\begin{array}{l}0.0005 \\
(0.39)\end{array}$ & $\begin{array}{l}0.0025 \\
(1.17)\end{array}$ & $\begin{array}{l}0.0035 \\
(1.56)\end{array}$ \\
\hline \# Observations & 538 & 538 & 242 & 242 & 296 & 296 \\
\hline
\end{tabular}




\section{Bar-Ilan University \\ Department of Economics \\ WORKING PAPERS}

1-01 The Optimal Size for a Minority

Hillel Rapoport and Avi Weiss, January 2001.

2-01 An Application of a Switching Regimes Regression to the Study

of Urban Structure

Gershon Alperovich and Joseph Deutsch, January 2001.

3-01 The Kuznets Curve and the Impact of Various Income Sources on the

Link Between Inequality and Development

Joseph Deutsch and Jacques Silber, February 2001.

4-01 International Asset Allocation: A New Perspective

Abraham Lioui and Patrice Poncet, February 2001.

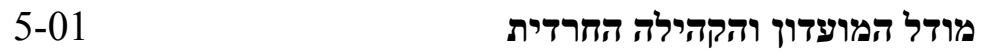

יעקב רוזנברג, פברואר 2001.

6-01 Multi-Generation Model of Immigrant Earnings: Theory and Application

Gil S. Epstein and Tikva Lecker, February 2001.

7-01 Shattered Rails, Ruined Credit: Financial Fragility and Railroad Operations in the Great Depression

Daniel A.Schiffman, February 2001.

8-01 Cooperation and Competition in a Duopoly R\&D Market

Damiano Bruno Silipo and Avi Weiss, March 2001.

9-01 A Theory of Immigration Amnesties

Gil S. Epstein and Avi Weiss, April 2001.

10-01 Dynamic Asset Pricing With Non-Redundant Forwards

Abraham Lioui and Patrice Poncet, May 2001.

Electronic versions of the papers are available at

http://www.biu.ac.il/soc/ec/working_papers.html 
11-01 Macroeconomic and Labor Market Impact of Russian Immigration in Israel

Sarit Cohen and Chang-Tai Hsieh, May 2001.

12-01 Network Topology and the Efficiency of Equilibrium Igal Milchtaich, June 2001.

13-01 General Equilibrium Pricing of Trading Strategy Risk Abraham Lioui and Patrice Poncet, July 2001.

14-01 Social Conformity and Child Labor

Shirit Katav-Herz, July 2001.

15-01 Determinants of Railroad Capital Structure, 1830-1885

Daniel A. Schiffman, July 2001.

16-01 Political-Legal Institutions and the Railroad Financing Mix, 1885-1929 Daniel A. Schiffman, September 2001.

17-01 Macroeconomic Instability, Migration, and the Option Value of Education Eliakim Katz and Hillel Rapoport, October 2001.

18-01 Property Rights, Theft, and Efficiency: The Biblical Waiver of Fines in the Case of Confessed Theft

Eliakim Katz and Jacob Rosenberg, November 2001.

19-01 Ethnic Discrimination and the Migration of Skilled Labor

Frédéric Docquier and Hillel Rapoport, December 2001.

1-02 Can Vocational Education Improve the Wages of Minorities and Disadvantaged Groups? The Case of Israel

Shoshana Neuman and Adrian Ziderman, February 2002.

2-02 What Can the Price Gap between Branded and Private Label Products Tell Us about Markups?

Robert Barsky, Mark Bergen, Shantanu Dutta, and Daniel Levy, March 2002.

3-02 Holiday Price Rigidity and Cost of Price Adjustment

Daniel Levy, Georg Müller, Shantanu Dutta, and Mark Bergen, March 2002.

4-02 Computation of Completely Mixed Equilibrium Payoffs

Igal Milchtaich, March 2002. 
5-02 Coordination and Critical Mass in a Network Market An Experimental Evaluation

Amir Etziony and Avi Weiss, March 2002.

6-02 Inviting Competition to Achieve Critical Mass

Amir Etziony and Avi Weiss, April 2002.

7-02 Credibility, Pre-Production and Inviting Competition in a Network Market

Amir Etziony and Avi Weiss, April 2002.

8-02 Brain Drain and LDCs' Growth: Winners and Losers

Michel Beine, Fréderic Docquier, and Hillel Rapoport, April 2002.

9-02 Heterogeneity in Price Rigidity: Evidence from a Case Study Using Micro-Level Data

Daniel Levy, Shantanu Dutta, and Mark Bergen, April 2002.

10-02 Price Flexibility in Channels of Distribution: Evidence from Scanner Data Shantanu Dutta, Mark Bergen, and Daniel Levy, April 2002.

11-02 Acquired Cooperation in Finite-Horizon Dynamic Games Igal Milchtaich and Avi Weiss, April 2002.

12-02 Cointegration in Frequency Domain

Daniel Levy, May 2002.

13-02 Which Voting Rules Elicit Informative Voting?

Ruth Ben-Yashar and Igal Milchtaich, May 2002.

14-02 Fertility, Non-Altruism and Economic Growth:

Industrialization in the Nineteenth Century

Elise S. Brezis, October 2002.

15-02 Changes in the Recruitment and Education of the Power Elites in Twentieth Century Western Democracies

Elise S. Brezis and François Crouzet, November 2002.

16-02 On the Typical Spectral Shape of an Economic Variable Daniel Levy and Hashem Dezhbakhsh, December 2002.

17-02 International Evidence on Output Fluctuation and Shock Persistence Daniel Levy and Hashem Dezhbakhsh, December 2002. 
1-03 Topological Conditions for Uniqueness of Equilibrium in Networks Igal Milchtaich, March 2003.

2-03 Is the Feldstein-Horioka Puzzle Really a Puzzle?

Daniel Levy, June 2003.

3-03 Growth and Convergence across the US: Evidence from County-Level Data

Matthew Higgins, Daniel Levy, and Andrew Young, June 2003. 